Christian Fernandes Gomes da Rosa

\title{
Eficiência como axioma da Teoria Econômica do Direito
}

Dissertação de Mestrado em Direito, na área de Filosofia e Teoria Geral do Direito, apresentada à Faculdade de Direito da Universidade de São Paulo, sob orientação do Prof. Dr. Celso Fernandes Campilongo, como requisito para obtenção do título de Mestre em Direito.

São Paulo

2008 
Rosa, Christian Fernandes Gomes da

Eficiência como axioma da teoria econômica do direito / Christian Fernandes Gomes da Rosa - São Paulo : C. F. G. da Rosa, 2008.

$108 \mathrm{p}$.

Dissertação (mestrado) - Faculdade de Direito da USP, 2008.

Orientador: Prof. Dr. Celso Fernandes Campilongo

Bibliografia.

Notas de rodapé.

1. Análise econômica do direito 2. Law and economics 3. Eficiência e direito I. Título. 


\section{Eficiência como axioma da Teoria Econômica do Direito}

Dissertação de Mestrado em Direito, na área de Filosofia e Teoria Geral do Direito, apresentada à Faculdade de Direito da Universidade de São Paulo, sob orientação do Prof. Dr. Celso Fernandes Campilongo, como requisito para obtenção do título de Mestre em Direito.

Banca Examinadora:

Prof. Dr. Celso Fernandes Campilongo

Presidente Orientador

Primeiro examinador

Segundo examinador

São Paulo, /2008. 


\section{AGRADECIMENTOS}

\section{Agradeço}

ao Prof. Dr. Celso Fernandes Campilongo, Professor Orientador que se fez amigo e sobretudo um exemplo de Docente e Profissional a ser sempre seguido,

à minha família, que sempre se fez presente em todos os momentos de minha vida, apoiando e estimulando a cada novo desafio enfrentado,

aos amigos Prof. Dr. Carlos de Abreu Boucault, Prof. Dr. José Luiz Horta,

Prof. Álvaro Mariano, Profa. Michele Cia, Prof. Fernando Rister, Profa. Viviane Gonçalves, Flávio Augusto de Carvalho, Maria Carolina Vastano e Natália Felix, que sempre estiveram dispostos a ajudar e a quem recorri inúmeras vezes.

e ao Fundo de Amparo à Pesquisa do Estado de São Paulo - FAPESP, que financiou os estudos que se consolidam neste trabalho. 


\section{RESUMO}

O presente trabalho é resultado de uma pesquisa que teve como objetivo a investigação sobre o possível desenvolvimento de uma nova teoria jurídica nos trabalhos vinculados a Law and Economics.

A hipótese testada ainda inclui a concepção de que essa Teoria Econômica do Direito teria a eficiência como seu fundamento moral, atribuindo ao Direito a função de maximização da utilidade, riqueza ou bem-estar sociais.

Para tanto, apresenta descrição sobre a maneira pela qual modelos e conceitos econômicos foram transformados em instrumentos metodológicos usados para descrever e fazer prescrições a respeito do conteúdo das regras jurídicas e de sua aplicação.

Este estudo ainda explora os mecanismos sociais de produção e aplicação do Direito, a fim de verificar como suas características podem limitar essa função maximizadora atribuída pela Análise Econômica do Direito.

Por fim, investiga-se quais recursos teóricos e retóricos tornaram utilizável pelo Direito o conceito puramente econômico da eficiência e o transformaram em um valor moral a guiar decisões jurídicas ou políticas. O consenso é, então, perquirido como o fundamento último sobre o qual se assentam a eficiência e a maximização como valores morais.

Palavras-chave:

Direito e Economia - Análise Econômica do Direito - Law and Economics

Teoria Econômica do Direito - Eficiência e Direito 


\begin{abstract}
This paper is a product of a research which aimed to study the potential development of a new legal theory within the paper works written by those authors usually associated with the Law and Economics School.

The hypothesis tested established the existence of an Economic Legal Theory that would be morally based on efficiency concepts and that assigned to the legal rules a function related to the maximization of social utility, wealth and welfare.

In order to accomplish this task, this paper presents a description of how economic models and concepts were turned into methodological instruments to describe and make prescriptions about the legal rules dispositions and their application.

Further, the research explores the social structures assigned to enact legal rules and those responsible for their enforcement, in order to verify how their qualifications are able to promote within the social rules efforts the function prescribed by the Economic Analysis of Law.

At last, this paper explores the theoretical and rhetoric instruments that made possible the use of the purely economic concept of efficiency into a moral value claimed as an ideal guide of political and legal decisions. The consent is, then, tested as the final basis on which efficiency and maximization as moral principles lay on.
\end{abstract}

Key words:

Economic Analysis of Law - Law and Economics - Efficiency and Law Economic Legal Theory - Efficiency and Moral 


\section{SUMÁRIO}

INTRODUÇÃO 2

1. TEORIA ECONÔMICA DO DIREITO 6

1.1. Análise Econômica positiva e a avaliação da eficiência do Direito 11

1.2. Análise Econômica Normativa e a função do Direito 19

1.3. Configuração de uma Teoria Econômica do Direito 26

1.3.1. Individualismo econômico e Direito 34

1.3.2. Qualificadoras da Teoria Econômica do Direito 37

2. FUNDAMENTOS DA TEORIA ECONÔMICA DO DIREITO 42

$\begin{array}{ll}\text { 2.1. Eficiência produtiva } & 47\end{array}$

$\begin{array}{lr}\text { 2.2. Eficiência alocativa } & 50\end{array}$

2.2.1. Critério Paretiano 53

2.2.2. Critérios compensatórios 55

2.3. Eficiência distributiva $\quad 59$

3. EFICIÊNCIA ECONÔMICA NA FORMAÇÃO DO DIREITO 62

3.1. Intervenção ótima do Direito 63

3.2. Função legislativa e a eficiência do Direito 68

3.3. Eficiência na interpretação do Direito 74

4. EFICIÊNCIA E MAXIMIZAÇÃO NA TEORIA ECONÔMICA DO DIREITO

4.1. Maximização da utilidade, da riqueza ou do bem-estar 82

4.2. Consenso como fundamento último para a Eficiência 89

4.3. Sensos de Justiça e a eficiência como valor 93

$\begin{array}{ll}\text { CONCLUSÃO } & 99\end{array}$

$\begin{array}{lr}\text { REFERÊNCIAS BIBLIOGRÁFICAS } & 101\end{array}$ 


\section{INTRODUÇÃO}

A Análise Econômica do Direito compõe uma corrente teórica e agrupa autores que, em comum, traçam observações e proposições a respeito do Direito e outras instituições sociais a partir de uma perspectiva econômica. Ainda que existam divergências internas significativas ou variantes que fujam à simples dicotomia DireitoEconomia, é possível apontar no trabalho de tais autores o desenvolvimento de uma peculiar teoria a respeito das manifestações sociais de caráter jurídico.

No que se refere a essas abordagens economicistas a respeito do Direito, o presente estudo tem por finalidade a investigação acerca de uma possível Teoria Econômica do Direito que teria se instituído paulatinamente através dos argumentos e debates entre os autores pesquisados. Essa nova teoria jurídica estaria fundada em um valor próprio: a eficiência ${ }^{1}$.

A presente pesquisa lança-se, portanto, no sentido de testar a hipótese de que a eficiência acabou por significar o lastro a partir do qual se construiu uma Teoria Jurídica economicista. Para tanto, foi preciso investigar qual o papel da eficiência nos trabalhos vinculados a Law and Economics, a fim de definir se é de fato adotada como um ponto de partida para a construção do pensamento econômico sobre o Direito estudado. Alternativamente, é preciso compreender qual a importância de outros conceitos e modelos econômicos, como aqueles baseados na racionalidade de agentes e no pressuposto do auto-interesse individual, além de definir se essas concepções são a base fundamental sobre a qual se erige a Análise Econômica do Direito quando esta se configura como Teoria Jurídica.

De maneira a categorizar os estudos que foram efetivados, é preciso esclarecer que a fundamentação de postulados teórico-jurídicos em um axioma é um tema afeito à Filosofia do Direito - ainda que seja um tema correlato à Teoria Geral do Direito, em função do possível desenvolvimento de uma teoria jurídica. Especialmente em uma perspectiva filosófica do conhecimento, foi objeto de investigação a maneira pela qual os autores estudados utilizam a eficiência econômica e a maximização da

\footnotetext{
1 Esclarece-se, desde logo, que na verdade há uma variedade de conteúdos semânticos possíveis relacionados a "eficiência". Algumas dessas distinções serão delineadas ao longo do presente estudo.
} 
utilidade ou riqueza como dispositivos a abalizar as decisões sociais, sejam elas de caráter mais pronunciadamente político ou, em especial, predominante jurídico.

Sem ignorar as divergências entre os autores e as escolas de pensamento a que são filiados, o que se intentará é apresentar um agregado possível dos postulados que tratam do Direito sob a perspectiva econômica. Trata-se de uma estratégia teórica voltada a viabilizar os objetivos da pesquisa, traçados da maneira mais ampla e inclusiva, sem, no entanto, ultrapassar demasiadamente a esfera já suficientemente complexa formada pelo Direito e Economia. Isso foi efetuado de maneira a evitar aprofundamentos possíveis em debates comportamentalistas sobre a razão humana ou discussões epistemológicas críticas mais gerais a respeito dos modelos teóricos modernos. São campos anexos ao que se estuda neste trabalho, mas que incluiriam excessivos problemas teóricos à pesquisa.

O tema em análise é de suma importância, uma vez que a Análise Econômica do Direito tem grande influência sobre o cenário jurídico - teórico e prático - em alguns países europeus e nos Estados Unidos da América e, gradativamente, ganha adeptos e capacidade de influenciar estudos, o desenvolvimento e a aplicação do Direito brasileiro. Ainda assim, pouca reflexão teórica tem sido dedicada a essa abordagem economicista em nosso país. Também por tal razão, da perspectiva da Teoria e Filosofia do Direito, é imperativo que se examine quão profícuos foram os estudos dessa corrente do pensamento a respeito do Direito, de modo a apontar os avanços e grau de peculiaridade que eventualmente tenham atingido nesse campo jurídico de investigação.

Para tanto, o estudo se desenvolverá a partir das obras e artigos publicados pelos autores que são relacionados como integrantes da ampla corrente conhecida como Law and Economics. Outros autores reconhecidos como puramente econômicos ou jurídicos também serão consultados de maneira a dar subsídio a comparações e esclarecer a origem de determinados argumentos erigidos dentro da Análise Econômica do Direito.

De modo a abranger tanto quanto necessário para a consecução de seus fins, a pesquisa começa por delinear os possíveis traços de uma nova teoria jurídica. Apresenta-se o problema da configuração de uma Teoria Econômica do Direito e debatese sobre as dificuldades para sua apreciação como tal. Busca-se, então, determinar quais seriam as principais qualificadoras dessa teoria, estabelecendo suas inquietações centrais e também classificar suas características marcantes. 
Exposta a idéia de uma Teoria Econômica do Direito, o presente estudo se dedicará a investigar os elementos fundamentais de teoria econômica que se portam como ferramentas cognitivas e teóricas para a descrição e prescrição acerca do Direito. Trata-se de uma busca por elucidar como os conhecimentos e técnicas econômicas vieram a se constituir como instrumentos para a teorização a respeito do fenômeno jurídico.

Ainda nessa esteira, os modelos econômicos, especialmente microeconômicos, serão revisitados a partir de uma perspectiva mais ponderada e detida, ainda que de maneira bastante pragmática - método muito comum aos textos de Law and Economics. O objetivo é reproduzir a releitura - em algum grau sociológica e metodológica, mas especialmente filosófica - que os autores da Análise Econômica do Direito fazem de tais modelos e conceitos a fim de transformá-los em base teórica para suas observações e proposições jurídicas.

O intento seguinte é demonstrar como tais argumentos economicistas a respeito do Direito se sistematizam ao compartilharem a concepção de que o Direito pode e deve ser pautado pela busca de sua adequação econômica.

Uma vez demonstradas as preocupações dos autores estudados quanto à necessidade de que o Direito seja economicamente qualificado, parte-se para o estudo das operações sociais fundamentais à construção e aplicação do Direito e passa-se a investigar se e como os modelos legislativos e a atividade interpretativa são capazes ou não de promover a eficiência nas relações interindividuais.

Ao final, aprofunda-se o estudo a respeito do conteúdo daquilo cuja maximização prescreve a teoria em estudo; ou seja, atenta-se para o problema da materialidade a ser promovida através dos discursos e técnicas da eficiência econômica do Direito. Uma vez que tenham sido apresentados os postulados primevos da Escola Utilitária Clássica, será possível traçar o debate contemporâneo a respeito do tema, travado entre as correntes da maximização da riqueza, de um lado, e da maximização do bem-estar, de outro.

Ainda nesse momento de investigação sobre os argumentos e mecanismos que se ocultam sob a idéia de eficiência como valor, haverá o intento em demonstrar a relação entre os critérios de eficiência, maximizadores da utilidade, riqueza ou bemestar, e noções mais usuais de justiça e moral que se rivalizam contemporaneamente para se alçarem ao posto de guia da construção e aplicação do Direito. 
Ao findar o trabalho, restará apresentar estudos sobre como os autores da Teoria Econômica do Direito buscaram estabelecer a eficiência como um valor moral fundado de modo subjacente no consenso presumível e baseou nesse valor suas ponderações normativas a respeito do Direito. 


\section{TEORIA ECONÔMICA DO DIREITO}

Neste primeiro segmento do trabalho, serão apresentadas as principais proposições do presente estudo, a partir das quais se desdobram os passos seguintes no sentido de compreender melhor os argumentos teóricos que se busca elucidar. Trata-se de um intento de isolar nas argumentações economicistas a respeito do Direito aquelas características idiossincráticas a fim de diferenciá-las com relação a outras perspectivas teóricas do Direito.

A Teoria Econômica do Direito que se tentará descrever nasceu em meio ao desenvolvimento dos trabalhos de autores vinculados a uma escola do pensamento denominada Economic Analysis of Law ou Análise Econômica do Direito. Esses mesmos autores podem ser agrupados em gênero mais amplo sob a denominação Law and Economics, que inclui pensadores que apresentam grau relevante de divergência tanto no que se refere aos pressupostos da teoria quanto na maneira com a qual abordam temas comuns.

Investigar a evolução dessas perspectivas é relevante para o estudo da construção da Teoria Econômica do Direito e isso será buscado, a partir da reconstrução das manifestações da Análise Econômica do Direito.

É possível afirmar que a Análise Econômica do Direito possuía, inicialmente, duas correntes principais, ambas desenvolvidas no início da Modernidade. Trata-se de uma divisão a respeito da abrangência dos estudos realizados e, hodiernamente, tal divisão já se vê um tanto desgastada em razão da evolução das pesquisas e perde lugar para outras classificações que revelam mais a respeito das divergências internas entre seus principais autores. De todo modo, essa primeira diferenciação será apresentada a fim de que se possa reconstruir a história recente do pensamento da Análise Econômica do Direito. ${ }^{2}$

A primeira, instaurada por Adam Smith em pleno século XVII, focou-se nas normas jurídicas que regulam o Mercado, regrando a atividade econômica. Esta se desenvolveu junto à maturação da Economia como uma ciência e com a expansão das

\footnotetext{
2 Cf. POSNER, Richard. Usos y abusos de la Teoría Económica en el Derecho. In: ROEMER, Andrés (Org.). Derecho y Economía: una revisión de la literatura. Fondo de Cultura Económica: Cidade do México, 2002. p. 66 e seguintes.
} 
preocupações a respeito da regulação do mercado pelo Estado, primeiramente, para a garatia do adequado funcionamento de seus mecanismos inerentes, supostamente suficientes para a boa condução das relações de troca de bens e serviços. Posteriormente, essa corrente se desenvolveu no sentido de estudar também a intervenção estatal no domínio econômico com a finalidade de implementar políticas públicas, desenvolvimento comercial e industrial ou então simplesmente para inibir as conseqüências pouco salutares decorrentes das falhas que se revelaram nesses mecanismos.

Essa Análise Econômica do Direito, como intérprete para o Direito das relações de mercado, foi muito expressiva no que se refere ao desenvolvimento de um sistema de direitos reais e na defesa de um aparato público que promovesse o adimplemento das obrigações, mas consolidou-se especialmente com a instituição do Direito da Concorrência ${ }^{3}$, cuja atuação se via mais diretamente ligada às atividades dos agentes no mercado: afastar as ineficiências e iniqüidades geradas por monopólios e trusts ${ }^{4}$.

A segunda corrente dessa escola foi instituída por Jeremy Bentham ${ }^{5}$ no século XVIII e cuidou em especial das normas que regulavam comportamentos alheios ao mercado, ocupando-se de interpretar relações jurídicas não econômicas sobre a perspectiva da Economia ou, ao menos, a partir de sua racionalidade própria, em especial um certo individualismo metodológico em que ao membro da sociedade é imputada a característica da busca do auto-interesse. Em outros termos, aludido autor foi o primeiro a alegar que, mesmo em campos em que o interesse pessoal não é evidente ou então os reais anseios são dissimulados, os indivíduos agem na sociedade em função de seu interesse próprio, buscando maximizar racionalmente suas vantagens em quaisquer relações, segundo parâmetros utilitários. Defendeu que a busca pela felicidade e o desejo de afastar a dor é o único mecanismo que efetivamente determina o sentido das ações humanas e, em seu aglomerado, de toda a sociedade ${ }^{6}$.

3 O Direito da Concorrência se constituiu ao longo da segunda metade do século XIX e tem no Sherman Act, promulgado em 1890 nos Estados Unidos da América, o seu grande marco institucionalizante.

${ }^{4}$ Basicamente, trusts são acordos entre agentes econômicos independentes, relacionados horizontalmente ou verticalmente, que definem variáveis importantes da oferta, como a quantidade ou preço, em prejuízo da concorrência nos mercados envolvidos.

5 BENTHAM, Jeremy. Uma Introdução aos Princípios da Moral e da Legislação. São Paulo: Abril, 1979.

${ }^{6}$ Tanto nos trabalho de Jeremy Bentham como nos de Adam Smith, é já manifesta a presença dos pressupostos que viriam a alicerçar toda a corrente mainstream das Ciências Econômicas, quais sejam a busca pela maximização da satisfação individual e a racionalidade dos agentes. 
Baseando-se nessas premissas defendidas pelo Utilitarismo desde o século XVIII, foi possível inserir nas então nascentes ciências sociais modernas a proposição de que os modelos de ação individual racional vinculada a fins autointeressados podem ser úteis para explicar não somente as relações cujo caráter econômico é óbvio, mas também aquelas em que a maximização racional das vantagens pessoais não parecia ser determinante da conduta.

Entretanto, as concepções trazidas por Bentham no que tange à interpretação econômica de relações alheias ao mercado foram escassamente trabalhadas por outros pensadores, pois muito poucos economistas - e número ainda menor de juristas - ocuparam-se em desenvolver ou demonstrar seus postulados, mantendo-se engajados em trabalhar com operações sociais em que as relações entre Economia e Direito eram mais evidentes, ou seja, seguindo uma linha marcadamente smithiana ${ }^{7}$.

É preciso esclarecer que o pensamento benthamiano foi, sim, desenvolvido por importantes filósofos e juristas ao longo dos séculos XVIII, XIX e até mesmo no século XX. No entanto, o foco manteve-se em outros elementos de seu pensamento (como aquele sobre a positividade do Direito), não vindo a se desenvolver com expressividade - até a eclosão da Análise Econômica do Direito do século XX - o seu individualismo sociológico utilitarista dentro do Direito.

Somente no século $\mathrm{XX}$, novos textos trouxeram à baila essa proposta de abordagem teórica; foram eles a monografia de Becker sobre a discriminação racial e seu artigo sobre a persecução penal ${ }^{8}$, o artigo sobre ilícitos do italiano Guido Calabresi ${ }^{9}$ e outro sobre a firma e sobre os custos sociais escrito por Ronald Coase ${ }^{10}$. Referidos trabalhos foram responsáveis por introduzir novamente nos debates acadêmicos a possibilidade de uma interpretação econômica das condutas humanas estranhas ao mercado. Tais papers, especialmente o de Coase, também acrescentaram novas ferramentas teóricas importantes na compreensão dessas relações individuais.

\footnotetext{
${ }^{7} \mathrm{Na}$ verdade, a união de Adam Smith e Jeremy Bentham sob uma mesma linha de pensamento é algo que se faz mediante uma reconstrução de suas argumentações, sendo razoável afirmar uma fundamentação metodológica comum, mas sem que se afirme uma vinculação tão explícita àquele tempo.

8 Respectivamente, The economics of discrimination. Chicago: University of Chicago Press, 1957 e Crime and Punishment: An Economic Approach. The Journal of Political Economy, Vol. 76, No ${ }^{\mathrm{o}}$ 2. p. 169-217. Março-Abril de 1968.

9 CALABRESI, Guido. Some thoughts on risk distribution and the law of torts. Yale Law Journal. No. 23, p. 499-553.

10 Respectivamente, The Nature of the Firm. Economica. N ${ }^{\circ} .4$. Novembro de 1937 e The problem of social cost. The Journal of Law and Economics. $\mathrm{N}^{\circ}$. 3. Outubro de 1960, ambos reeditados em COASE, Ronald. The Firm, the Market and the Law. Chicago: University of Chicago, 1990.
} 
A partir da década de 1970, muitos foram os responsáveis pelo aperfeiçoamento de ambas correntes da Teoria da Análise Econômica do Direito, sendo imprescindível citar autores como Thomas Ulen, Robert Cooter, Steven Shavell e Richard Posner ${ }^{11}$.

Esses autores, sejam eles mais voltados a uma ou outra corrente interna da Análise Econômica do Direito ou mais ou menos adeptos de abordagens positivas ou normativas $^{12}$, têm em comum o fato de que seus pressupostos e postulados, como supra indicado, são tributários do pensamento econômico clássico e neoclássico, ainda que com algumas divergências. São esses, entre outros de mesma linhagem, os principais responsáveis pelos trabalhos que frutificaram na Teoria Econômica do Direito que se apresenta no presente estudo.

Contudo, é imperativo que se esclareça que nem todos os trabalhos que se caracterizam pela abordagem econômica do Direito são relacionáveis à Escola Neoclássica da Economia ${ }^{13}$, já que esses autores somam-se aos neo-institucionalistas na constituição de uma corrente mais ampla, conhecida por Law and Economics, responsável pelo aprimoramento das perspectivas econômicas do Direito. Essa vertente mais abrangente e flexível é, no presente trabalho, agregada a fim de conformar o que se propôs denominar Teoria Econômica do Direito.

A inserção dos avanços conceituais praticada pelos neo-institucionalistas capacita os instrumentos da Economia a compreender fenômenos mais complexos e especialmente aquelas realidades socioeconômicas que se distanciam mais dos modelos ideais de mercado. A Escola Institucionalista ${ }^{14}$, de uma maneira geral, estabelece a crítica de que as teorias econômicas Clássica e Neoclássica ignoraram um aspecto fundamental da realidade econômica: as instituições. Em seus modelos microeconômicos - em que o mercado é o objeto privilegiado das investigações - pouco foi explicado sobre o cenário em que suas transações se estabelecem e como isso é capaz de modificar o conteúdo das relações entre indivíduos e grupos.

11 Todos os autores tiveram suas principais obras apontadas nas Referências Bibliográficas.

12 O tema é desenvolvido em próximos subitens.

13 Tradição que teve sua origem nos primeiros textos smithianos, enfrentou franca evolução nos debates marginalistas e segue alterando suas concepções. Mais será esclarecido sobre essa Escola Econômica no próximo capítulo

14 Contemporaneamente, tem em Oliver Williamson seu principal representante. 
Para o presente estudo, os neo-institucionalistas são muito relevantes, já que, fundados nas observações e categorias trazidas pelo Teorema de Coase $^{15}$, esses autores se prestaram a estudar as circunstâncias nada ideais através das quais as instituições - inclusive jurídicas - se desenvolvem, o que possibilitou a comparação das peculiaridades de economias diferentes e, inovadoramente, a demonstração da influência que o cenário institucional é capaz de exercer sobre as relações dos agentes econômicos e sobre a constituição das organizações e regras sociais.

Mais do que observar essas entidades como agentes típicos de mercado, igualados também ao tipo de homem econômico - como fazem os Neoclássicos - e figurados como ofertantes ou demandantes de bens, o Institucionalismo busca investigar as razões pelas quais as instituições se constroem na sociedade e como se estruturam os incentivos sociais à sua atuação e desenvolvimento ${ }^{16}$. A estrutura de incentivos, "regras do jogo", em si também é vista como integrante do quadro de instituições que, contingentes, podem apresentar configuração mais ou menos adequada do ponto de vista da eficiência comparada ${ }^{17}$..

Apresentada essa divisão de cunho mais histórico, é possível passar a proposição de uma outra separação entre autores e textos relacionáveis a Law and Economics. Uma separação possível é feita de acordo com as perspectivas de análise a que se propõem, ou seja, de acordo com os objetivos teóricos presentes quando do uso do ferramental economicista na abordagem de temas jurídicos, sejam eles meramente descritivos ou caracterizados pela normatividade. Segundo tal critério, pode-se diferenciar a Análise Econômica Positiva e a Análise Econômica Normativa do Direito.

Ainda que seja defensável a existência de uma relação de continuidade entre as duas, alegando-se que uma observação descritiva qualquer é seguida explícita ou implicitamente por uma normativa, também é possível indicar características próprias em cada um desses dois movimentos de perscrução do Direito.

Referida distinção de abordagem tem sua origem na própria Teoria Econômica, na qual é recorrente tema de explanações e debates. Não há muito que

${ }^{15}$ O Teorema de Coase postula que em circunstâncias ideais em que os custos de transação são nulos, a alocação inicial de direitos não é relevante para a alocação final de recursos, que transitarão mediante transações para as mãos daqueles que lhe aferem maior valor.

${ }^{16}$ É preciso esclarecer que, diferentemente da Teoria Econômica Neoclássica, o Institucionalismo não reconhece a existência viável de uma situação ótima ideal, promovendo a concepção de que é possível apenas reconhecer situações relativamente eficientes mediante a comparação de cenários distintos e igualmente factíveis.

${ }^{17}$ NORTH, Institutions, institutional chance and economic performance. $18^{\text {th }}$ impr. Cambridge: Cambridge University Press, 2005. 
diferir das qualificações dessas duas abordagens no que se refere à Economia pura, pois é basicamente o mesmo instrumental que veio a ser utilizado para desenvolver as análises do Direito.

Desse modo, enfatiza-se que os termos "positivo" e "normativo", como será possível compreender nas próximas páginas, são utilizados dentro da Teoria Econômica do Direito segundo sua conceituação nas ciências econômicas, a princípio não apresentando exata identidade com a maneira em que são usados na tradicional Teoria do Direito.

É preciso ainda relatar que para alguns autores ${ }^{18}$ existe, ao lado das análises positiva e normativa, uma terceira divisão possível que se apresentaria como uma Análise Econômica Funcionalista do Direito, que teria na Universidade da Virginia seu referencial teórico. No entanto, são tantas as semelhanças entre essa terceira corrente e as anteriores - em especial a análise normativa - que se dispensa o trato diferenciado de suas proposições no presente estudo. Para os fins almejados, seguir a maioria dos autores de Law and Economics e estabelecer as possíveis distinções entre a análise positiva e a normativa será suficiente.

\subsection{Análise Econômica positiva e a avaliação da eficiência do Direito}

A Análise Econômica Positiva do Direito teria como seu centro de debates a Universidade de Chicago e uma das razões para seu desenvolvimento seria a influência que grandes economistas tiveram na Escola de Direito daquela instituição. Na maioria dos textos da área, Ronald Coase e Guido Calabresi são citados como seus fundadores, mas foi na obra de Richard A. Posner que se deu seu maior desenvolvimento ${ }^{19}$.

Essa vertente caracteriza-se por abordar o sistema jurídico tal como ele se apresenta na sociedade. Em suas interpretações, discorre a respeito dos efeitos das normas vigentes e busca demonstrar os incentivos que se conformam em decorrência da realidade institucional tal qual ela se configura.

\footnotetext{
18 PARISI, Francesco. Positive, Normative and Functional Schools in Law and Economics. European Journal of Law and Economics, vol. 18, $\mathrm{n}^{\circ}$. 3, Dezembro de 2004.

${ }^{19}$ PARISI, Positive, Normative and Functional Schools in Law and Economics, p 8.
} 
Em razão de seu caráter meramente descritivo - e não prescritivo - tende a ser apontada como livre de ideologia ou isenta da adoção de primado político, já que, segundo afirmam seus autores, efetua tão somente uma observação munida do instrumental mais técnico das Ciências Econômicas, especialmente sua sociologia e teoria microeconômica.

Em sua vertente mais purista, não possui o arrojo de se propor a encontrar as possíveis soluções dos problemas que se detectam, mas tão somente - na verdade, isso não é pouco - o de relatar as conseqüências desejáveis e indesejáveis decorrentes de qualquer norma posta. Ainda que geralmente façam uso de seus instrumentos apenas para verificar o sistema de incentivos econômicos e sociais já criados pelas normas vigentes, análises positivas não raramente se empregam a prever, segundo os modelos econômicos, quais as conseqüências possíveis de propostas de alteração das normas. Isso é efetivado sem que se promova claramente uma análise normativa, já que tais trabalhos evitam juízos de valor sobre as proposições, restringindo-se a relatar seus possíveis efeitos.

Há, no entanto, grande desconfiança acerca da possibilidade de se traçar comentários estritamente técnicos a respeito de qualquer fator social sem que, ao mesmo tempo, tenha-se em mente alguma modalidade de valor referencial - no caso desses teóricos, algum critério de adequação econômica ou, mais explicitamente, de eficiência. Isso aproximaria muito a Análise Positiva e a Análise Normativa do Direito, o que leva à crença de que se trata de uma divisão de cunho mais didático do que efetivamente teórico.

No entanto, parece razoável crer que, ao menos no que se refira à produção científica, a adoção de uma das duas perspectivas altera - e muito - os objetivos a serem alcançados por qualquer estudo. Dessa maneira, ainda que os pressupostos e modelos econômicos que dão base a ambas análises sejam praticamente os mesmos, os resultados podem sim apresentar características distintas.

No que se refere a sua metodologia de abordagem, a Análise Econômica Positiva do Direito caracteriza-se pela marcante abordagem empirista que geralmente parte da adoção dos modelos econômicos, especialmente aqueles denominados neoclássicos. Isso significa a admissão mais ou menos explícita de que o aumento de riqueza, por exemplo, em razão de melhor eficiência alocativa, pode ser averiguado em relações voluntárias em mercados reais - ou hipotéticos. 
Em outros termos, vale dizer que o uso de tais modelos econômicos pela análise descritiva parte do pressuposto de que, em circunstâncias ideais, a barganha operacionalizada nas relações entre os agentes tenderia a gerar um equilíbrio próximo o bastante de uma situação de eficiente alocação. O intuito de cada agente em maximizar sua satisfação teria a capacidade, por si só, de melhor destinar os recursos, empregandoos onde tenham maior valor e, portanto, nas mãos de quem lhes dá maior valor ${ }^{20}$.

Como a alocação - ou realocação - de recursos depende muito de transação entre as partes, é possível ver nos estudos da Teoria Econômica do Direito a respeito de contratos a base conceitual a partir da qual se constrói um mecanismo de avaliação da intervenção do Direito em qualquer modalidade de relação interindividual. Em outras palavras, a análise dos aspectos econômicos embutidos nos negócios transações que formalmente se juridicizam ou não - conformam um instrumento metodológico de avaliação de quaisquer relações humanas.

Tais relações se dão sob regras (constraints) e estas influenciam os resultados agregados do agir social. Por tal razão, a Análise Econômica Positiva toma por referência os modelos econômicos que versam sobre o agir individual em face dos "direitos" ${ }^{21}$ de propriedade e das transações realocativas para desenvolver suas análises e previsões.

Em sua tarefa de ponderar as resultantes econômicos e sociais da escolha de uma dada configuração normativa, a Análise Positiva se propõe a um desafio quase especulativo, já que as relações decorrentes de norma são, algumas delas, involuntárias e, portanto, não há equilíbrio "natural" a ser atingido. Alguma modalidade de equilíbrio $^{22}$, neste caso, depende da substância da regra jurídica e, assim sendo, torna-se importante, mas difícil, que se investigue minuciosamente o quadro de incentivos gerados por qualquer regra jurídica.

Para proceder a essa investigação, a abordagem econômica positiva do Direito torna-se possível através da comparação entre a realidade, tal qual se observa, e um parâmetro proposto pelos modelos ideais, a fim de aferir a eficiência apresentada

20 A maneira pela qual esses conhecimentos de economia pura transformam-se em um instrumentos sociológicos e filosóficos a compor um valor moral são debatidos no Capítulo 2 e 4.

21 É sempre conveniente lembrar que, em termos econômicos, "direitos de propriedade" são quaisquer vantagens que possam derivar da detenção sobre um bem, material ou imaterial. Trata-se de um termo bastante inclusor, uma vez que até mesmo a posse de um título pode ser dispensada para a caracterização dessa relação de uso e fruição.

${ }^{22}$ Refere-se aqui a busca de situações ótimas ou, quando inalcançáveis, de situações de menores perdas para o agregado social. 
pelas relações individuais sob a norma que, não totalmente voluntárias, variam em adequação econômica em graus. Ou seja, é preciso avaliar se a mimetização de mercado ideal instituída pelo Direito é adequada segundo o que o conhecimento econômico tem a dizer sobre a reação dos homens a incentivos.

O parâmetro adotado, portanto, configura-se como aquela situação ótima existente em condições ideais e, quando esse é contrastado com o arranjo presente na realidade, constrói-se não somente uma descrição dos incentivos instituídos, mas também torna-se possível um julgamento a respeito de sua adequação econômica.

Assim, comparando os dados da reações forçadas pela norma com as que se efetivariam em um mercado livre de custos de transação ou outras imperfeições, verifica-se o grau de eficiência atingido pela norma (mercado mimetizado) em relação ao mercado ideal ${ }^{23}$.

Muitas áreas do Direito poderiam ser consideradas para esclarecer mais casuisticamente do que se trata a Análise Econômica Positiva. Temas como o efeito deterrente de um sistema penal ${ }^{24}$ ou os resultados de diferentes regras de organização societária $^{25}$, por exemplo, já foram reiteradamente tratados a partir dessa perspectiva economicista descritiva.

Opta-se, no presente estudo, por demonstrar como tais análises são feitas com relação àquelas micro-relações que compõem os mercados, sejam eles ideais, reais ou hipotéticos. Assim, elege-se os o tema das transações - ou contratos - para demonstrar como os conhecimentos oriundos de modelos econômicos são instrumentalizados para abordar a relação entre a norma e a realidade em que se insere.

Desse modo, no que se refere aos contratos, amplamente considerados, que corporificam as transações interindividuais, é possível haver do Direito uma atuação bastante incisiva e, de acordo com a maneira com a qual esta se apresenta, é possível avaliar se sua substância é capaz de gerar os incentivos adequados ou então fomenta resultados economicamente indesejáveis.

É preciso saber que o sistema jurídico pode apresentar soluções para dois problemas comuns a contratos firmados. Pode, ao menos, (i) coibir o comportamento abusivamente oportunista e (ii) tratar da incerteza frente a situações imprevistas que

\footnotetext{
${ }^{23}$ POSNER, Richard. Economic Analysis of Law. 6a. ed. Aspen: Nova Iorque, 2003.

${ }^{24}$ BECKER, Crime and Punishment.

${ }^{25}$ WINTER, Ralph. State Law, Shareholder protection and the Theory of the Corporation. Journal of Legal Studies, vol. 6, p- 251-292, 1977.
} 
venham a exercer influência sobre a transação, ao esclarecer as partes previamente acerca da alocação dos riscos, mesmo quando ela não é prevista nas cláusulas ajustadas ${ }^{26}$. Se os riscos contratuais ou extra-contratuais, revela a análise descritiva, não forem imputados àqueles que a menor custo possam evitar eventos danosos, cria-se o incentivo para que as devidas precauções não sejam tomadas e, por conseqüência, maior incidência de eventos indesejáveis venha a acometer a relação ${ }^{27}$.

É preciso lembrar que tais interveniências das regras jurídicas não se fazem necessárias somente em negócios mercantis propriamente ditos, mas pode ir além dessa limitação a fim de incidir sobre quaisquer relações sociais de maneira economicamente esclarecida, a fim de promover a eficiência no mais vasto espectro das ações sociais.

Segundo as análises econômicas positivas, há incertezas decorrentes de contratos - ou relações - de longa duração que encarecem sobremaneira as transações. Dessa análise descritiva, geralmente parte-se para a proposição de que, assim sendo a realidade socioeconômica, essas ineficiências decorrentes da falta de segurança pelo diferimento no tempo do momento para o cumprimento obrigacional devem ser suprimidas por um sistema que, aberto para informar-se com os costumes do mercado e as razões que dão causa à relação, seja incisivo ao assegurar a satisfação das razoáveis expectativas das partes, promovendo a execução do acordado sempre que cabível ou, em sua impossibilidade, a reparação dos danos sofridos ${ }^{28}$.

As condutas das partes antes da assinatura dos termos e quando do cumprimento de suas obrigações devem estar em conformidade com o que é esperado dos agentes daquele mercado, traçando-se para isso um parâmetro bastante objetivo da conduta adequada esperada a fim de que se estimule o comportamento cooperativo e maximizador entre os interessados.

O afastamento desse paradigma em razão da busca abusiva por melhor oportunidade - em detrimento flagrante e incompensado de outra parte ou terceiro deve receber do Direito a punição que transforme a oportunidade de um em algo indiferente para a outra parte. Basta exigir a compensação que se daria caso os custos

\footnotetext{
${ }^{26}$ Os contratos, considerados como os instrumentos que consolidam transações interindividuais, são incompletos, já que o custo de prever todas as contingências possíveis excede o razoável e arcar com tais investimentos poderia, na maioria das relações, inviabilizar a transação.

27 POSNER, Economic Analysis of Law, p. 118.

28 Não que as expectativas das partes sejam uma medida perfeita para o reequilíbrio da relação transacional, mas é um referencial adequado já que sua adoção como parâmetro alivia as partes de investir demasiados recursos na securitização de seus negócios. POSNER, Idem, p. 122.
} 
transacionais fossem baixos e, portanto, o descumprimento fosse maximizador da utilidade agregada das partes.

É preciso observar, no entanto, que o aceite aos inadimplementos que maximizem a riqueza agregada das partes pode gerar a noção de que, sob esse sistema jurídico, há permissividade quanto ao oportunismo, o que pode encarecer as transações futuras. Por isso, mesmo quando eficiente (Kaldor-Hicks), convém sinalizar que o descumprimento obrigacional só foi aceito mediante a indenização adequada da outra parte de modo a demonstrar que essa não se viu em pior situação (Pareto) ${ }^{29}$.

Qualquer situação avessa aos ditames decorrentes da transposição dos modelos econômicos às relações econômico-sociais pode instituir uma variedade de incentivos indesejáveis no curto ou longo prazos. Por essa razão, em relação às transações que se desenvolvem nos mercados, o Direito não pode permanecer omisso a certas disposições a fim de que não seja preciso desfazer o negócio e tampouco gastar demasiado montante de recursos na responsabilização pelos eventuais desequilíbrios, ainda que persistam falhas nos mercados, sejam os contratos incompletos ou até mesmo quando sobrevenham circunstâncias imprevistas. A sinalização clara do Direito a respeito da alocação desses riscos pode poupar recursos antes e durante a vigência da relação ${ }^{30}$.

Ainda nesse tema, a relevância do Direito como árbitro extravasa os limites contratuais e também é extremamente influente quando da alocação da responsabilidade sobre riscos entre os indivíduos que não se vêem a princípio vinculados por uma relação contratual, já que imputa conseqüências às pessoas por seus atos. Tratase da questão da responsabilidade.

Prevêem os estudos econômicos que uma adequada distribuição dos riscos é aquela que faz com que recaiam sobre os indivíduos que podem contribuir para evitá-los, de maneira a lhes atribuir o ônus de tomar as medidas e sanar as incorreções que poderão afetar terceiros. Nesse tema, a Análise Econômica Positiva se presta a verificar se os incentivos gerados por regras de responsabilidade - civil, administrativa

\footnotetext{
${ }^{29}$ A diferença entre as duas modalidade de aferimento de adequação econômica será melhor delineada em próximo capítulo.

30 SHÄFER, Hans-Bernd. OTT, Claus. The economic analysis of Civil Law. Northampton: Edward Elgar, 2004. p. 277 e MICELI, Thomas. Economics of the Law.Oxford: Oxford University Press, 1997., p. 72 e seguintes.
} 
ou penal - que estejam conformando um sistema adequado de respostas jurídicas aos ilícitos ${ }^{31}$.

Outro aspecto que tangencia a questão dos incentivos criados pelo Direito no relacionamento entre indivíduos, reza a doutrina econômica que normas podem também impedir que o oportunismo excessivo gere conseqüências perniciosas antes mesmo do estabelecimento de uma transação, o que importa, especialmente, em promover uma conduta dos agentes em que a disponibilidade de informações seja a mais alta possível. O Direito tem, assim, um papel importante na promoção da transparência nos mercados - explicitamente econômicos ou de caráter econômico oculto - de modo a viabilizar um cenário em que relações não cooperativas possam se tornar cooperativas, situação em que a soma da utilidade ou riqueza dos envolvidos seja maximizada. Conferir as propriedades das regras vigentes no que se refere ao disclosure de informações em mercados onde há flagrantes assimetrias ou espaço para atuação de insiders e oportunistas é outra tarefa usualmente enfrentada por textos classificados como de Análise Positiva do Direito.

Ainda a fim de obstar as vantagens individuais possíveis decorrentes de situações socialmente ineficientes ${ }^{32}$, o Direito pode desempenhar um papel importante ao manter um aparato que force o cumprimento obrigacional de modo a diminuir os custos relacionados a investimentos idiossincráticos e de difícil realocação ${ }^{33}$.

Um ordenamento pode possuir um "desenho" que crie os incentivos à promoção do desenvolvimento ou então que favoreça o oportunismo, o rent seeking ${ }^{34}$, o aproveitamento exagerado de informações privadas ou posições privilegiadas e assim conforme a um cenário de grandes perdas comparadas. A análise econômica descritiva do Direito se propõe a elucidar as conseqüências desejáveis ou nefastas de um determinado arranjo institucional - mormente jurídico.

\footnotetext{
31 . POLINSKY, A. Mitchell. An introduction to Law and Economics. 3a. ed. Aspen: Nova Iorque, 2003. p 17.

${ }^{32}$ Com "situações socialmente ineficientes" refere-se àquelas em que não há maximização da utilidade, riqueza ou bem-estar agregados.

33 JOSKOW, Paul. Contract duration and relationship-specific investments. The American Economic Review.vol. 77. no. 1. p. 168-185. Março de 1987.

${ }^{34}$ Rent seeking é a busca socialmente indesejável de um indivíduo por se beneficiar de transferências de riqueza. Sua inadequação econômico-social configura-se sempre quando tal realocação se dá em prejuízo da riqueza agregada da sociedade. TOLLISON, Robert. Rent seeking. In: NEWMAN, Peter (Ed.) The New Palgrave Dictionary of Economics and the Law. New York: Palgrave MacMillan, 2002. p. 315.
} 
$\mathrm{Na}$ busca permanente de se abstrair das questões evidentemente mercantis, essas ferramentas teóricas têm seu uso ampliado de maneira a que seja possível também reconhecer e descrever os incentivos existentes em qualquer relação entre indivíduos.

Assim, apesar do exposto citar os argumentos de análise positiva específicos sobre como as relações contratuais se organizam em um sistema em que se reconhecem direitos de propriedade, o que a Análise Econômica do Direito busca é a aplicação desses mecanismos a quaisquer relações interindividuais - inclusive naquelas em que o caráter econômico de transação fica obscurecido, tais como relações familiares e fraternais. Para muitos dos autores dessa Teoria, mesmo nessas modalidades de interação social há aplicabilidade dos instrumentos metodológicos de análise das Ciências Econômicas e, portanto, fazendo uso desse instrumental diferenciado, a relação entre Direito e fatos passa a ser descrita de maneira que se mantenha o foco nas conseqüências socioeconômicas das regras jurídicas.

É preciso ter em mente, entretanto, que os teóricos que se empregam a fazer análises econômicas positivas puras geralmente negam qualquer caráter de juízo sobre essas conseqüências da norma e, portanto, trazem para si a qualificação de neutralidade que lhes reservaria sua condição científica. Nesse sentido, quando e se possível a extração de qualquer elemento normativo da Análise Econômica do Direito, esta toma a configuração de uma verdadeira "Economia do Direito", distanciando-se em alguma medida da idéia de uma teoria jurídica - ao menos da maneira em que se costuma reconhecê-la.

No entanto, qualquer análise meramente descritiva pode ser - e geralmente é - seguida do julgamento sobre a qualidade dos incentivos criados pelo Direito, juízo esse que está a um só passo da configuração da normatividade economicista, tema das páginas seguintes. 


\subsection{Análise Econômica Normativa e a função do Direito}

Ao contrário da anterior, a Análise Econômica Normativa do Direito busca, em suas observações, ir além da mera descrição da realidade jurídico-institucional e suas conseqüências socioeconômicas. A Análise Normativa é qualificada por seu caráter, sobretudo, prescritivo. Para isso, toma por pressupostos os conhecimentos de teoria micro e macroeconômica e, mediante a adoção de um objetivo a ser alcançado, preceitua as modificações normativo-institucionais que deveriam ser efetuadas a fim de que as regras passem a promover um fim explicita ou implicitamente eleito ${ }^{35}$.

A adoção de tal objetivo a ser efetivado pela sociedade, no entanto, decorre, para alguns, de uma decisão de caráter político - ou então filosófico. Em razão disso, essa abordagem, prescritiva, é tida como menos técnica que a anterior.

Para a conformação de uma Teoria Econômica do Direito, no entanto, essa perspectiva de análise, normativa ou funcional, é de suma importância, já que seus autores são praticamente uníssonos ${ }^{36}$ na defesa da maximização - da riqueza, bem-estar ou utilidade agregada - como fim último a ser viabilizado ou instituído pelo Direito. Para tanto, fazem uso dos modelos teóricos econômicos para revelar e prescrever as mudanças necessárias para que as normas vigentes sejam aperfeiçoadas e passem a estabelecer incentivos que levem os indivíduos a comportamentos e relações que promovam maior grau de eficiência. Eficiência, assim, passa a ser a finalidade básica do Direito $^{37}$.

Nesses termos, nos trabalhos normativistas de Law and Economics se caracteriza a noção de eficiência como um referencial a avaliar a adequação das normas vigentes. Também é identificável a transformação da busca pela maximização em finalidade a ser alcançada mediante a proposição de novas regras jurídicas. Vê-se, na utilização desses recursos, o método argumentativo muito comum a debates morais, qual seja, o juízo entre bom ou ruim, adequado ou inadequado, apropriado ou inapropriado. ${ }^{38}$

\footnotetext{
35 A promoção de ideais a reformar o Direito vigente de modo a que passe a ser racionalmente mais adequado do ponto de vista maximizador é, aliás, outro ponto comum entre a Teoria Econômica do Direito que se apresenta e os postulados da Escola Utilitarista Clássica fundada por Jeremy Bentham.

${ }^{36}$ PARISI, Positive, Normative and Functional Schools in Law and Economics, p. 18.

${ }^{37}$ HANSON, Jon. HART, Melissa. Law and Economics. In: PATTERSON, Dennis (ed.). A Companion to Philosophy and Leal Theory. Malden: Blackwell, 2005. p. 312.

38 “Critérios que são usados para determinar o que é 'bom', ou 'melhor', ou 'o melhor' devem trazer uma definição do que é 'bom', 'melhor' ou 'o melhor'. Determinar o que é ‘bom’ não pode, pode definição,
} 
Além disso, a maneira com que são tratadas as questões políticas pelos teóricos de Law and Economics reforça a idéia de que o senso de adequação econômica está acima do sistema de decisões políticas, vez que até mesmo este pode ser verificado quanto a seu ajustamento em termos de sua eficiência ${ }^{39}$.

Desta maneira, nos textos normativistas estudados, a decisão a respeito do valor a ser utilizado como referencial deixa de ter caráter propriamente político, ou seja, não é fruto de uma decisão coletiva ou pública. A eleição desse valor passa a ter cunho quase filosófico, sem deixar de ser economicista, já que estabelece a eficiência como um verdadeiro princípio moral a ser perseguido, pelo Direito e pelos agentes de Estado, a cada decisão tomada. A eficiência como ponto de partida para as análises prescritivas parece tomar ainda lugar de maior destaque quando se percebe que sua adoção sequer é questionada na grande maioria dos textos normativistas. Ao contrário, ela é assumida ainda que implicitamente - como algo dado, valor eleito, a partir do qual qualquer argumento prescritivo se desenvolve.

Institui-se a eficiência, portanto, como um axioma, e passa a ser aplicada como um princípio que deve sensibilizar os agentes que instituem políticas e constroem as normas e também aqueles que se empregam em sua interpretação e aplicação. Tratase de um amplo campo prescricional. Em outros termos, "os verdadeiros benefícios de Law and Economics, segundo os normativistas, está em identificar e deixar claro aos legisladores e juízes as reformas que são - e as que não são - necessárias para o bem da eficiência." $"$.

É certo que essas características da Análise Econômica Normativa oferecem ao Direito um padrão de qualidade a seguir, de modo que suas conseqüências na realidade socioeconômica estejam em conformidade com o que se pode esperar de sua incidência.

Entretanto, vai-se além de tecer um paradigma comparativo. Ao estipular um fim a ser atingido pelas instituições jurídicas, acaba por lhes imputar uma função específica. A Análise Econômica do Direito, ao fazer uso do conhecimento econômico

ser um processo livre de valores.” ZERBE JR., Richard. Economic efficiency in Law and Economics. Northampton: Edward Elgar, 2001. p. 14.

$39 \mathrm{O}$ tratamento que os teóricos de Law and Economics dão às instituições políticas será avaliado no Capítulo 3.

${ }^{40}$ HANSON, Jon. HART, Melissa. Law and Economics. In: PATTERSON, Dennis (ed.). A Companion to Philosophy and Leal Theory. Malden: Blackwell, 2005 p. 325. 
para interpretar as ações sociais, acaba por incumbir ao Direito - e não somente ao ramo do Direito Econômico - uma função sócioeconômica específica.

O Direito teria, em face dessa sua capacidade de moldar incentivos e guiar as condutas humanas, a possibilidade de maximizar a riqueza da sociedade ao intervir nas relações sociais de modo a promover a mais eficiente alocação dos recursos disponíveis. É importante sempre lembrar que o debate sobre recursos não trata exclusivamente do dinheiro ou de bens e serviços explicitamente ofertados em mercados, mas de recursos em amplo sentido, de maneira a incluir aqueles bens e serviços cujas ofertas e demandas se vêem obscurecidos por relações de natureza aparentemente não econômica.

Essa distinção se faz necessária frente ao reconhecimento de que nem sempre há moeda envolvida na relação social, como por vezes também não o há na transferência evidente ou oferta mercantil das utilidades. Exemplo comum entre os teóricos da Análise Econômica do Direito de intercâmbio de utilidades sem a contraprestação pecuniária é o trabalho doméstico da mulher à sua família. Mesmo em tais casos, a Teoria defende a possibilidade de que a lógica inerente ao raciocínio econômico seja utilizada para guiar a interpretação das relações intersubjetivas ${ }^{41}$.

A prescrição por fomentar a riqueza, ademais, não trata da vinculação a patrimônios individuais e a seu desenvolvimento. Pode significar a busca por aumentar a soma das utilidades extraídas dos limitados recursos do corpo social, este composto pela soma de indivíduos. Somente haverá flagrante perda de riqueza social quando os ganhos de qualquer das partes envolvidas não forem suficientes para compensar os danos sofridos por outra ou por terceiros; nesta última circunstância, não se operou eficientemente $^{42}$.

Apesar de mais se focarem na questão pura da eficiência, mesmo autores como Richard Posner, radical defensor da eficiência como parâmetro para decisões, chegou a reconhecer, em seus primeiros estudos, que há a influência de outros valores nas condutas humanas socialmente direcionadas, cedendo ao afirmar que há limites éticos a obstar a busca exclusiva por eficiência ${ }^{43}$.

\footnotetext{
${ }^{41}$ POSNER, Economic Analysis of Law, p. 145.

${ }^{42}$ Faz-se referência ao critério mais flexível de eficiência e não o paretiano, que exige a inexistência de perdas de todas as partes envolvidas ou eventualmente atingíveis pelos efeitos da transação. Vide Capítulo 2.

${ }^{43}$ POSNER, Idem, p. 11.
} 
A definição de tal limite, no entanto, fica pouco claro entre os autores dessa corrente do pensamento jurídico, pois a maximização da riqueza acabou por tornar-se, especialmente para referido autor, um valor prioritário, imbuído de sua própria fundamentação moral, a ser efetivado. Dessa maneira, é possível traçar nos próprios estudos de Law and Economics uma eventual diferenciação entre ética e moral. Aquela representa os valores que podem influenciar a atividade individual, mas que fazem referência a tradições religiosas, costumes locais, princípios de conduta não economicistas, de um modo geral. A ética é tratada como um fator que pode coincidir com a busca da eficiência ou então se interpor nesse empreendimento, dependendo de como atua no caso concreto.

Em razão de características humanas não exatamente econômicas nem economicamente avaliáveis (ao menos não diretamente), a noção de utilidade sofre influência desses valores éticos. Uma vez que pessoas não crêem que sua própria felicidade seja a única coisa importante, há um volume de satisfação pessoal que alguém pode estar disposto a perder para que o outro a receba ${ }^{44}$.

Além disso, no embate entre ética e uma moral econômica ou utilitarista, desenvolvem-se debates a respeito da adequação de certas distorções como aquela que se constitui na aceitação do sacrifício de alguns pelo beneficio de uma maioria ou então no caso do utility monster, em que o prazer do criminoso supera a dor de suas vítimas - o que, em fria análise, justificaria a agressão; ambas as situações parecem respeitar a idéia de maximização da satisfação agregada.

Dessa maneira, na busca por melhor explanar e caracterizar essas figuras com as quais trabalha a Análise Econômica do Direito, muito já foi debatido no sentido de coibir abusos e maus usos de suas assunções.

O Direito, pois, como sistema de tomada de decisão ou, ao menos, como meio através do qual as opções serão implementadas, pode (descritivamente) ou deve (normativamente) zelar pela melhor alocação possível de recursos sociais a fim de maximizar a riqueza ou bem-estar dos indivíduos que compõem a sociedade, sempre observando, no entanto, limites globais de coerência com a idéia de maximização, já que análises irrefletidas podem levar a aplicações distorcidas da Análise Econômica.

De qualquer forma, é preciso investigar os argumentos sobre os quais se assentam as prescrições desses autores. Uma vez adotada a pressuposição de que o

\footnotetext{
44 Esse argumento será tratado no Capítulo 4.
} 
mercado é o alocador ideal de recursos e, portanto, a situação de equilíbrio indicada por um mercado ideal é a conjuntura de maior maximização de riqueza agregada, logo se conclui que a interferência do Estado, em primeiro momento, é prescindível.

No que se refere a isso, os adeptos da Teoria da Análise Econômica do Direito defendem a concepção de que as relações privadas, perfazendo-se autonomamente, tendem a gerar melhor alocação dos recursos sociais, pois são capazes de processar melhor a informação difusa na sociedade e, portanto, de maneira mais eficiente.

Trata-se da informação quanto aos interesses em jogo, as expectativas de benefícios ou valor de utilidade e ainda dos custos tidos como aceitáveis ou não pelos agentes. Não se refere somente àqueles inerentes às relações obviamente econômicas (compra e venda de produtos, transferência de direitos reais et coetera), mas também dá pertinência econômica a fatos como o interesse em contrair matrimônio ou praticar um ilícito, já que todos eles podem ser reduzidos a expectativas de satisfação e intercâmbios de utilidades mediante a aceitação de custos presentes ou futuros ${ }^{45}$.

Segundo a corrente mais radical dessa Escola, um ente centralizado, público, não teria capacidade alguma para planejar adequadamente, ou seja, com eficiência, a maneira como essas relações se efetivam. Nessa concepção, o Estado intervencionista seria um óbice ao equilíbrio a ser alcançado espontaneamente na sociedade.

Há, no entanto, uma evolução no discurso sobre o papel do Direito como viabilizador das relações privadas e já existe ampla aceitação quanto à atuação do Estado junto aos particulares de maneira a criar os pressupostos necessários ao processamento difuso de informações, ao desenvolvimento de transações a baixos custos e, ao final, ao equilíbrio possível em cada um dos mercados. Essa função poderia se resumir, grosso modo, a baixar os custos de transação, de um lado, e promover as correções e compensações necessárias em sistemas que - diferentemente do ideal - apresentam custos de transação positivos, de outro lado.

No cumprimento de sua função socioeconômica, é preciso que o Estado promova, entre outros fatores, a clara definição dos direitos de propriedade, a manutenção de alto fluxo de informações na sociedade e correção pontual daquelas

\footnotetext{
${ }^{45}$ POSNER, Economic Analysis of Law, p. 148.
} 
relações em que, em razão da inoperância dos itens anteriores, não for possível a consecução independente dos fins almejados.

A definição quanto aos direitos de propriedade é necessária para que os agentes privados, agindo conforme seu interesse, possam se relacionar uns com os outros, realocando recursos escassos e buscando satisfazer seus interesses e afastar danos a seu bem-estar. É preciso saber o que é de quem antes que seja possível transacionar e, quando for o caso, afastar a turbação que é causada por terceiro. Ainda nessa elementar, é indispensável que se conforme uma estrutura institucional que assegure a negociação da propriedade sobre os bens, ou seja, é preciso desenvolver um locus institucional de intercâmbio entre utilidades.

Agrega-se a esses elementos, complementarmente, a função do Direito de promover o aumento do fluxo de informação na sociedade, evitando que grandes assimetrias informacionais entre os pactuantes possam levar a um ponto de equilíbrio que não o mais eficiente possível. A disponibilidade de informações torna menos custosa e mais producente a relação a se efetivar.

Seria papel inafastável do Direito, por exemplo, interferir adequadamente naquelas relações em que, em função das circunstâncias de fato, não é possível haver certeza quanto aos direitos de propriedade ou, em termos mais amplos, quanto à propriedade dos benefícios decorrentes do gozo de um bem. Também seria preciso a interferência naquelas em que é impossível promover "naturalmente" suficiente fluxo de informações e transações - o que ocorre em função, especialmente, de um elevado custo transacional ou detenção de situação privilegiada de uma das partes. Por fim, seria necessária alguma atuação do Direito quando, apesar da presença desses fatores de eficiência, não se opera o rápido equilíbrio ideal.

Como conseqüência de falhas inerentes aos mercados ou ainda em razão de especificidades tais como impedimentos culturais, necessidades de escala ou inafastabilidade de situação monopolística, algumas transações seriam inviáveis ou então não seriam capazes de gerar eficiência. Nesses casos, configura-se também como uma função do Direito, ao lado de outras possíveis regras sociais, intervir, mimetizando um mercado ideal - mecanismo privado - de maneira a implementar o equilíbrio que seria alcançado em circunstâncias perfeitas - ou chegar o mais próximo disso. Em outros termos, mais inclusivos, as regras jurídicas têm a função de viabilizar transições para situações institucionais em que os mecanismos de mercado sejam capazes de promover a 
maximização do bem-estar social, o que faz deste a finalidade mediata a ser perseguida pelo Direito.

Mesmo quando o mercado é incapaz de gerar efetivamente uma situação alocativa ótima, ao mimetizar relações voluntárias ideais, o Estado, pelo Direito, é capaz de estimular decisões em que o resultado de bem-estar ou riqueza agregados seja alçado e ainda pode estabelecer a efetiva compensação daqueles que se viram prejudicados pela decisão - neste último caso, pela intervenção compensadora forçada do Estado, é possível afirmar o alcance final de uma eficiência paretiana.

Constitui-se, assim, a idéia de que o Direito tem uma função socioeconômica específica na sua intervenção sobre todas as relações privadas: promover a eficiência. Não só nas relações cujo caráter econômico seja evidente, mas também naquelas em que esse fator - o auto-interesse - não parece ser determinante da ação social.

Essa idéia decorre, sociologicamente, da crença de que cada indivíduo sabe, mais que qualquer agente público, o que é melhor para si, cabendo às regras jurídicas apenas a criação de um ambiente favorável à maximização do bem-estar. Pressupõe, ainda, que um indivíduo decide em função da maximização de seus interesses, em face de uma realidade de incentivos proporcionada pelo aparato institucional.

Em face da apresentação de tais argumentos, é possível constatar que a Análise Econômica do Direito coloca, em sua Teoria do Direito, o seu objeto como imprescindível para a sociedade. É ele que, mediante as características de norma cogente, cujo cumprimento (enforcement) é promovido por um aparato público e pelas partes interessadas, é capaz de balizar a atividade privada e, assim, estipular de maneira adequada as regras do agir social ${ }^{46}$.

Dessa maneira, a fim de sumariar, parece que a perspectiva normativa da Análise Econômica fica caracterizada por sua abordagem prescritiva dos temas que aborda e a determinação de uma função a ser exercida pelo Direito. Ambos elementos fundamentais na configuração de uma Teoria Econômica do Direito propriamente dita.

\footnotetext{
46 A idéia de que pessoas interessadas podem tomar parte na coerção do Direito não significa a involução a uma situação de exercício da vingança privada. Demonstra, sim, como os próprios indivíduos podem barganhar e agir estrategicamente ao tomar a alocação de direitos e responsabilidades conforme estabelecida pelo Estado como ponto de partida para suas relações interindividuais.
} 


\subsection{Configuração de uma Teoria Econômica do Direito}

Descritas e analisadas as duas principais perspectivas distinguíveis dentro de Law and Economics, o que se buscará é demonstrar como essas concepções acabaram por construir uma cadeia de argumentos e proposições que as fazem constituir uma possível Teoria Econômica do Direito.

Desde logo, é possível afirmar que não se trata de uma teoria que se proponha a determinar a diferenciação absoluta ou "natureza" do Direito. Aliás, para a maioria dos teóricos da Análise Econômica, o Direito é pressuposto como oriundo, de maneira geral, do Estado, ou seja, sua fonte é pública e sua guarda independe diretamente de recursos privados.

No entanto, ao invés de se promover a investigação a respeito dessa sua característica de oficialidade ou então traçar elementos de sua validade formal, a Teoria Econômica do Direito - ao modo que o faz um de seus precursores, Jeremy Bentham reconhece a caracterização estatal do Direito como algo dado, posto, que se verifica empiricamente e não se define abstratamente.

Isso fica pouco explícito na maioria dos trabalhos de Posner sobre Law and Economics, mas fica mais claro que ele compartilha dessa concepção em seus livros mais teóricos. A palavras de Shavell ${ }^{47}$, ao esclarecer incidentalmente o que chama de Direito em um de seus trabalhos, também torna evidente essa abordagem despreocupada com um rigor em uma definição estrutural:

Por Direito eu obviamente trato do corpo de regras que chamamos de jurídicas, ou seja, as regras que são determinadas e são feitas cumprir pelo Estado e que têm por escopo conduzir comportamentos e resolver certos eventos de conturbação.

No que se refere a diferenciação do Direito, não se perde de foco o fato de que o Direito estatal coexiste ao lado de outras regras sociais a compor a estrutura de controle das condutas individuais. No entanto, o que pode parecer uma abordagem comum sobre a diferenciação entre a "natureza" de regras jurídicas e regras sociais

\footnotetext{
${ }^{47}$ SHAVELL, Steven. Foundations of Economic Analysis of Law. Cambridge: Harvard, 2004. p. 229.
} 
revela-se imbuída de uma comunhão entre as funções socioeconômicas que ambas devem cumprir e, dessa maneira, torna-se comum a análise de qual é o nível ótimo, mais eficiente, do uso de normas jurídicas ou estritamente sociais na criação de incentivos adequados a conduzir os comportamentos individuais em uma sociedade ${ }^{48}$.

Assim, não se nota grande esforço a fim de estabelecer uma diferenciação rigorosa quanto às naturezas próprias de regras jurídicas e demais regras sociais. Os autores parecem reconhecer pragmaticamente a diferença através do status que uma regra possui de acordo com as suas características ou origem e, portanto, sua qualificação relevante se dá em razão do grau e modalidade da coerção, sempre avaliados da perspectiva de suas funções socioeconômicas compartilhadas ou complementares.

De uma maneira geral, a questão formal a respeito do Direito é deixada em segundo plano, o que faz parecer que a Teoria Econômica do Direito é construída de maneira a se tornar uma alternativa às abordagens "tradicionais", formalistas, a respeito do Direito - sem, no entanto, que esse fosse um objetivo claramente traçado e defendido por qualquer de seus autores de maneira mais detida. Muitas vezes essa dualidade é tratada apenas incidentalmente, especialmente quando está em debate uma comparação entre o resultado provável de uma aplicação formal do Direito e, de outro lado, a solução ofertada por uma análise economicista do problema jurídico. Entretanto, é possível encontrar textos em que essa oposição é tratada a partir de uma perspectiva menos casuística e, portanto, mais geral e teórica ${ }^{49}$.

De qualquer forma, é uma tarefa importante delinear as críticas de alguns autores de Law and Economics ao formalismo e, a seguir, buscar reconstruir os argumentos utilizados para a instituição de uma alternativa teórica, descrevendo especialmente os instrumentos retóricos e sociológicos de que se fez uso.

Sobre o formalismo, Posner afirma que podem levar tal classificação as concepções jurídicas que fazem do silogismo uma ferramenta na descoberta das respostas jurídicas ou então as que vêem nos textos legais e constitucionais todo o seu arcabouço para a construção lógica de soluções a problemas que se apresentam perante o

\footnotetext{
${ }^{48}$ SHAVELL, Steven. Law versus Morality as regulators of conduct.: American Law and Economics Review. Vol. 4. No. 2. 2002. p. 227

${ }^{49}$ Dentre os principais teóricos de Law and Economics, Richard Posner parece ser aquele que mais se empregou a debater esse tema da oposição, ainda que não absoluta, entre o formalismo jurídico e a análise econômica do Direito. Em especial, o fez de modo mais detido em duas de suas obras, quais sejam The problems of Jurisprudence Cambridge: Harvard University Press, 1990. e Law, Pragmatism and Democracy. $2^{\mathrm{a}}$. impressão. Cambridge: Harvard University Press, $2003 .$.
} 
Direito e seus intérpretes quando do julgamento. Uma concepção ampliada de formalismo, para Posner, segue:

O sentido mais útil desse termo multiforme deriva, contudo, do contraste entre forma e substância - forma referindo-se ao que é interno ao Direito e substância ao que lhe é extrínseco, como no contraste entre justiça formal e justiça material. ${ }^{50}$

Sob essa perspectiva, o objetivo do estabelecimento desse contraste entre forma e substância é, sobretudo, garantir a autonomia do Direito e prescindir de elementos sociais outros para apontar e explicar aquilo que the caracteriza, sua "essência", mesmo quando esse se modifica no tempo e no espaço. Essa busca incisiva por proporcionar ao Direito um distanciamento dos demais conhecimentos das Ciências Sociais parece, sob a perspectiva da Análise Econômica, desnecessária.

Munidos de algumas qualificadoras que poderiam trazer coerência e estabilidade à aplicação da norma, acaba por limitar sua capacidade de reconhecer elementos fundamentais que se ocultam nos processos transacionais que revestem qualquer tipo de relação social.

De um lado, não é capaz de se questionar profundamente sobre que movimentos sociais existem antes da formalização do ato humano em ato jurídico. Não é caracterizado - o formalismo - pela grande habilidade de reconhecer possíveis interesses individuais subjacentes aos discursos coletivistas imbuídos no texto normativo, seu principal instrumento.

De outro lado, o formalismo exclui de sua análise as conseqüências do conteúdo das normas ou de sua aplicação no contexto socioeconômico. A resposta jurídica dada pelos textos normativos, em um exame formalista, esgota o espaço social que o Direito pode alcançar. Assim, com funções substanciais inexistentes ou limitadas e sem uma finalidade declarada, o Direito se restringe a um exercício lógico ou retórico cuja adequação - vale dizer, validade - se assenta não nas conseqüências que produz, mas no respeito desses limites auto-impostos ou obediência talvez substancial de sua coerência interna.

Afastado de um valor fixo a guiá-lo, o Direito - segundo o formalismo seria mais capaz de dizer que respostas não são juridicamente adequadas do que apontar

${ }^{50}$ POSNER, The problems of Jurisprudence. Tradução de Jefferson Luiz Camargo em POSNER, Richard. Problemas de Filosofia do Direito. São Paulo: Martins Fontes, 2007. p. 53 
uma solução ótima para um problema jurídico. Os teóricos econômicos do Direito mais otimistas, por sua vez, se reservam essa capacidade ${ }^{51}$.

É claro que essa mesma crítica - a do reducionismo exagerado de assunções - dirigida ao formalismo também pode ser trasladada aos métodos econômicos de abordagem do Direito que, baseados fundamentalmente em modelos microeconômicos ideais, também reduzem a realidade social para compreendê-la ${ }^{52}$.

Em uma perspectiva mais crítica ou cética, o apoio na noção econômica do ceteris paribus, um dos pressupostos de análises econômicas mais complexas, já deslocaria o conhecimento econômico a uma categoria de irreal ou meramente especulativo. Esse mecanismo se dá através do estudo isolado de apenas algumas variáveis, assumindo a estabilidade nos demais fatores que poderiam influenciar o objeto estudado. Mas dessa acusação as Ciências Econômicas também se defendem; nas palavras de Hausman, “cláusulas ceteris paribus são parte de toda ciência. Ao invés de condená-las por completo, é preciso distinguir quando alguém pode legitimamente empregá-las e reconhecer que generalizações grosseiras podem ter seu valor e conteúdo apesar de serem vagas e imprecisas."

Para Posner ${ }^{54}$, entretanto, a razão jurídica - pura - ainda estaria em desvantagem, já que não teria a capacidade de responder a muitos problemas importantes do Direito porque não seria um método voltado para a construção de soluções, mas de eliminação seletiva de possíveis resoluções. O formalismo seria mais bem adaptado para avaliar que respostas não são jurídicas e, portanto, não devem ser adotadas, ao invés de - como se propõe uma análise normativista da Teoria Econômica do Direito - apontar um encerramento sócio e economicamente adequado ao problema.

Como uma alternativa a essas concepções limitadoras arraigadas à cultura jurídica, os estudos da Análise Econômica do Direito se colocariam com suas análises descritivas e prescritivas, nos moldes já explanados. Isso se deu, no entanto, de maneira gradual e sem a pretensão explícita e coletiva do desenvolvimento de uma Teoria

\footnotetext{
${ }^{51}$ Parece haver, no entanto, uma expressiva evolução no sentido de se afirmar que resultados ótimos, ideais, são impraticáveis e o que se pode alcançar, mesmo munidos das mais variadas ferramentas de análise socioeconômica, é uma situação superior, economicamente mais adequada, mas imperfeita já que essa não seria viável.

52 WHITE, James B. Economics and Law: two cultures in tension. In: DAU-SCHIMIDT, Kenneth. ULEN, Thomas. Law and Economics Anthology. $2^{\text {nd }}$ pr. Cincinnati: Anderson, 2002. p. 52.

${ }^{53}$ HAUSMAN,Economic methodology in a nutshell. Journal of Economic Perspectives. Vol. 3. No. 2. Primavera de 1989. p. 118.

${ }^{54}$ POSNER, The problems of Jurisprudence, p. 37.
} 
Econômica a respeito do Direito. Essa, que parece ter se configurado, pode ter ocorrido quase espontaneamente.

É notório que o Direito sempre foi, em maior ou menor grau, tema recorrente dos trabalhos da Ciência Econômica. No entanto, como já apontado, somente no século XX começaram a surgir, efetivamente, tentativas de fazer uso de instrumentais econômicos e, portanto, não tradicionais - ao menos não juridicamente usuais - para a descrição e construção do pensamento a respeito do Direito.

Se num primeiro momento os trabalhos na área limitavam-se a debates pontuais do relacionamento entre Direito e Economia e sequer havia a declaração auto reflexiva de que poderia criar algo de efetivamente peculiar, com o vagar do tempo o pensamento ganhou bastante sistematização e tornou-se viável reconhecer todo um conjunto de pensamentos economicistas sobre o Direito e, em suas formulações, uma Teoria Econômica do Direito.

Muito já se falou sobre a Análise Econômica do Direito e as maneiras pelas quais faz das manifestações jurídicas seu objeto. No entanto, não basta demonstrar seus argumentos para que se aponte sua configuração como Teoria. É preciso isolar nesses argumentos o que de fato pode caracterizá-los como um movimento teórico inovador em suas proposições. Isso pode ser feito mediante o delineamento do papel que tais argumentações dão ao Direito perante a sociedade e descrever a maneira peculiar através da qual perfaz as observações desse seu objeto.

Mas apresentar de maneira indefectível a constituição de uma verdadeira Teoria do Direito por essas argumentações economicistas não é tarefa simples. Não restam dúvidas sobre a pluralidade de teorias a respeito do que se denomina Direito na sociedade moderna. No entanto, é possível que se escolha e exija certas características de uma dada argumentação para que lhe seja aferida a condição de uma Teoria do Direito. Essas serão buscadas.

O problema é que a seleção desses requisitos se dá de maneira bastante controversa já que, para tanto, é preciso que haja algum referencial neutro a ser comparado com as novas considerações a fim de que se possa definir sua condição. Não se refuta a concepção de que a escolha de um referencial é importante para que se conforme as condições que, quando atendidas, seriam suficientes para coerentemente apontar que se trata de uma efetiva teoria jurídica. No entanto, a própria eleição do referencial não pode ser feita senão sob fortes influências conceituais e teóricas. 
Desse modo, nem sempre é apropriado apresentar a teoria hegemônica e, mediante suas qualificadoras, procurar as mesmas características nas novas argumentações para, somente então, reconhecer a existência de uma outra teoria que lhe seja alternativa ${ }^{55}$.

Em face disso, implanta-se um dilema. Modificam-se os requisitos para a configuração de uma Teoria do Direito ou então muito pouco será doravante reconhecido como tal, instalando-se uma exclusividade em que uma única vertente do pensamento se reserva a capacidade de argumentar sistematicamente a respeito do tema, segundo seus critérios e limites próprios.

De outro lado, é defensável a concepção de que é fundamental a presença de qualificadoras para a aceitação de que se trata de uma Teoria do Direito propriamente dita, sob pena de que qualquer observação pouco típica seja considerada uma nova teoria. Essas qualificadoras talvez se assentem não só na peculiaridade das novas argumentações, como também em sua capacidade de coerência interna e utilidade em seu reconhecimento como movimento teórico independente.

É certo que cada teoria tem maiores capacidades de explanar alguns aspectos de seu objeto em prejuízo de outros e bem poucas delas clamam para si a capacidade de manifestar em si totalmente a realidade ou natureza de seus artigos de estudo. Especialmente em razão disso, o empobrecimento que, eventualmente, poderia causar a negação da pluralidade teórica fica tanto mais evidente em face da complexidade social ${ }^{56}$.

Mediante a manipulação das ferramentas teóricas também utilizadas pelos autores da Análise Econômica do Direito, é possível construir experimentalmente uma proposição economicista para defender a importância da pluralidade de teorias a partir de um argumento concorrencial, de modo a que seja satisfeito o critério relacionado à utilidade desta teoria.

A adoção hegemônica de uma determinada teoria jurídica pelos profissionais do Direito pode ter grandes efeitos na realidade socioeconômica uma vez que afeta a maneira pela qual o Direito reconhece os fatos, bem como altera sua capacidade para conhecer as conseqüências de suas intervenções. Teorias jurídicas

\footnotetext{
55 Refere-se à Teoria Pura do Direito, segundo a qual o Direito é restringido em sua abrangência, bem como muito delimitado metodológica-estruturalmente. KELSEN, Hans. Teoria pura do Direito. $7^{\mathrm{a}}$. Ed. São Paulo: Martins Fontes, 2006.

56 BIX, Brian. Jurisprudence: Theory and context. 3rd. Ed. London: Sweet and Maxwell, 2004. p. 4.
} 
podem oferecer níveis diferentes de segurança institucional, adequação social ou eficiência econômica, na medida em que mantêm seu foco prioritário na estrutura do que se denomina Direito ou então em sua funcionalidade. Em face disso, é útil estabelecer algum grau de concorrência entre perspectivas diferenciadas a respeito do Direito, a fim de que prevaleçam - ou coexistam - as concepções que, de maneira agregada, possam oferecer mais à sociedade. Ademais, esta teoria sob investigação propõe-se, com bom grau de sucesso, a descrever de maneira mais realista as relações sociais (interindividuais) sob o Direito e, normativamente, estabelecer um critério valorativo que é, acima de tudo, útil.

Nesse contexto, afastar sumariamente a qualificação teórico-jurídica de uma corrente do pensamento a respeito do Direito em razão de suas peculiaridades metodológicas - por suas observações fazerem uso de modelos de outra disciplina obstruiria a possibilidade de que se conheça sua utilidade, com os prejuízos que desse fato advém. Eis um dos motivos pelos quais se torna conveniente diminuir a importância que critérios tradicionais têm para a definição de novas teorias e voltar-se a atenção às peculiaridades das novas observações, bem como à utilidade que sua adoção pode oferecer.

Reitera-se que isso não significa o abandono absoluto de critérios para que se tome conhecimento da configuração de uma teoria a fim de que levem para si essa condição apenas aquelas argumentações que possuam certa coerência entre seus pressupostos e postulados e somente reunidos sob uma mesma qualificação as proposições que tenham o suficiente em comum.

A consistência dos argumentos teóricos é, inclusive, um dos critérios apontados por Richard Posner ${ }^{57}$ quando trata do problema da caracterização de teorias. Além desse, segundo o autor, tudo que se pode demandar é algum grau de abstração e generalidade. Exigir outras características específicas pode configurar a adoção, ainda que despercebida, de uma vinculação a uma teoria pretérita.

Essas duas qualificações mínimas parecem estar presentes na postulada Teoria Econômica do Direito. Não se deve, entretanto, concluir com isso que não existam contradições e divergências entre aqueles que partilham de variações de uma mesma teoria, já que muitas vezes essas são demonstrações de que esse movimento

\footnotetext{
${ }^{57}$ POSNER, Richard. Conceptions of Legal “Theory”: a response to Ronald Dworkin. Arizona State Law Journal. $N^{\circ} .29$. 1997. p. 379.
} 
teórico continua em evolução. Essas contrariedades existem e persistem em Law and Economics e, ainda assim, parece haver uma série de abordagens e conclusões comuns entre seus autores.

Além do mais, a importância de que se reconheça a condição teórica de determinadas proposições reside no fato de que essa adoção propriamente revela uma nova teoria para o mundo do pensamento jurídico e permite que seus postulados sejam amplamente conhecidos e debatidos.

Torna-se imprescindível, então, procurar, nas argumentações desenvolvidas pelos teóricos da Análise Econômica do Direito traços mínimos de uma teoria verdadeiramente jurídica, revelando os problemas que lhe servem de objeto para, então, verificar se há qualquer peculiaridade na abordagem de tais tópicos.

De pronto, é possível afirmar que questões recorrentes da jurisprudencia como “O que é o Direito?”, "Qual seu papel na Sociedade?” e "Que valores o Direito deve perseguir?" são também alvo de ponderações de autores da Análise Econômica do Direito. Por vezes, tais temas são tratados por essa corrente do pensamento econômicojurídico moderno de maneira pouco usual, através da implementação de pressupostos atípicos para o estudo habitual do Direito e de metodologia específica, que empresta das Ciências Econômicas.

É bem verdade que o problema da definição do Direito - tema máximo das teorias estruturalistas do Direito - é pouco tratado nos textos de Law and Economics e apenas incidentalmente aparece nos trabalhos de seus principais autores. Uma possível exceção a essa regra são textos em que Richard Posner estabelece como seu objeto um debate mais teórico a respeito do Direito ou de outras teorias jurídicas. No entanto, mesmo quando se propõe a abordar a temática da distinção do Direito e identificar o que lhe é essencial, conclui por uma postura que pode ser definida como relativista, já que crê na possibilidade de se compreender o que é o Direito apenas circunstancialmente, e chega a reputar a pergunta “o que é o Direito?” como fútil ${ }^{58}$.

As razões de Posner para tal afirmativa se assentam na irrelevância de uma resposta exata a respeito do que é Direito para que se desenrolem fatos históricos ${ }^{59}$

\footnotetext{
58 POSNER, Richard. Law and Legal Theory in the UK and in the USA. Oxford: Clarendon, 1996. p. 2 e seguintes.

59 Trata-se do problema dos tribunais especiais pós-guerra, especificamente o de Nuremberg, em que considerações diferenciadas a respeito do que é Direito - que mantinham os Estados Unidos e o Reino Unido - não impediram que o julgamento se efetivasse,
} 
que dependeriam dessa resposta, mas também na mutabilidade do conteúdo do Direito e a incerteza a respeito da aplicabilidade do Direito no tempo e no espaço.

Os argumentos apresentados por Posner quando enfrenta esses temas geralmente não são explicitamente de caráter econômico e, ainda que de fato tal autor raramente se distancie em absoluto de suas posições economicistas, torna-se difícil estabelecer tais textos como uma confrontação direta do problema da "natureza" do Direito efetuada pela Law and Economics. Deste modo, esses trabalhos não são capazes de revelar uma posição doutrinária específica da Análise Econômica sobre a essência caracterizadora do Direito e, assim, não se perfaz de maneira abstrata e genérica uma caracterização singular, inovadora, do Direito.

O fato de que o tema é escassamente tratado pela Teoria Econômica do Direito, entretanto, é capaz de revelar que, em seu bojo, não é essa a grande preocupação no que se refere às características que as instituições jurídicas podem - ou devem apresentar. A ausência de textos mais aprofundados a respeito do problema da essência configuradora do Direito indica que outra deve ser a faceta jurídica em que se debruçam seus autores. O foco das atenções da Teoria Econômica do Direito parece ser composto por duas outras variáveis do debate jurídico, quais sejam a finalidade e função do Direito, que nestes argumentos economicistas se vêem intimamente vinculadas.

Para que se possa compreender melhor as características dessa Teoria Econômica do Direito e as funções que ela atribui às instituições jurídicas, é preciso entender como se tornou possível a construção de seus argumentos descritivos e normativos. Demonstrar essa inovação não seria possível sem tocar, ainda que brevemente, nos aspectos sociológicos e metodológicos subjacentes.

\subsubsection{Individualismo econômico e Direito}

A idéia de que uma Teoria Econômica do Direito teria maiores capacidades de solucionar os conflitos e atingir objetivos entregues às instituições jurídicas funda-se, sociologicamente, na crença de que a maneira pela qual a Economia considerou a decisão e ação individuais diz muito mais a respeito da realidade do que a concepção jurídica tradicional do sujeito de direitos, que qualifica o indivíduo como 
figura detentora de direitos. Mesmo para a sociologia jurídica hegemônica, o indivíduo é comumente descrito como aquele para quem agir conforme a regra é um valor a ser implementado em sua conduta.

A Escola Econômica Neoclássica, origem majoritária das concepções de que a Teoria Econômica do Direito faz uso, pressupõe características específicas dos agentes sociais na construção de seus modelos. Em seus postulados, o foco das atenções científicas recai sobre o indivíduo, mas - assim caracteriza-se a principal distinção da sociologia jurídica - supõe-se que suas ações são determinadas, primordialmente, em razão de seus próprios interesses. Trata-se claramente de uma abordagem possibilitada pelo uso de tipos ideais diferenciados.

Seguindo as palavras de Weber, é preciso esclarecer que os tipos ideais não se estabelecem como a constatação histórica das características de um determinado indivíduo nem necessariamente como a configuração, empiricamente observada, de um dado número de indivíduos em um acumulado montante de casos. Tampouco carrega consigo a preocupação estrita com a verdade das coisas, descoberta como fruto de investigação metafísica. Trata-se de uma ferramenta de abordagem científica da realidade e da conformação de modelos que, apesar de não a retratarem em absoluto, ajudam a compreendê-la ${ }^{60}$.

O tipo ideal homos oeconomicus, figura da qual faz uso a Teoria Econômica, pressupõe-se que o indivíduo aja de maneira racional, determinando sua ação de modo a que possa alcançar seu fim, que se qualifica na satisfação de seus interesses $^{61}$.

No entanto, é preciso esclarecer que a adoção do pressuposto de que o indivíduo seja racional não significa que é imprescindível que a ação seja, em todo e qualquer caso, efetivada sob plena consciência e farta disponibilidade de informação. Não se ignora o fato de que nem sempre o agente possui bastante informação disponível e, tantas vezes, o alto custo de se adquirir dados para subsidiar uma decisão absolutamente ciosa pode tornar a sua busca algo absolutamente irracional em termos de custo-benefício. Para a conformação da teoria, basta assumir a presunção de que as

\footnotetext{
${ }^{60}$ WEBER, Max. Economia e Sociedade. 4a. ed. Vol. 1. Brasília: Universidade de Brasília, 2004. p. 4.

${ }^{61}$ Nos termos da sociologia clássica, trata-se do determinante de sentido "racional referente a fins", ou seja, definidas "por expectativas quanto ao comportamento de objetos do mundo exterior e de outras pessoas, utilizando essas expectativas como 'condições' ou 'meios' para alcançar fins próprios, ponderados e perseguidos racionalmente, como sucesso". Ibidem, p. 15.
} 
pessoas têm a capacidade e a tendência de fazer uso da razão para viver, suprir suas necessidades e buscar satisfação. ${ }^{62}$

Ainda no que se refere à racionalidade, novas abordagens do Direito efetuadas por autores vinculáveis a Law and Economics dão tratamento bem menos ideal à questão e são capazes de explicar como as decisões são tomadas mediante insuficiência de informações ou por uma racionalidade enviesada ${ }^{63}$, sem, no entanto, que tais instrumentos deixem de ser ferramentas bastante úteis às investigações jurídicas ${ }^{64}$.

No que se refere à busca pela satisfação pessoal, é possível traçar um paralelo com as doutrinas utilitaristas. Lembra-se que nessa escola do pensamento filosófico prevalece a concepção de que o indivíduo age socialmente de maneira a maximizar a sua própria felicidade e, no que se refere à esfera daquilo que é público, defende que o Direito deve pautar-se de maneira a instituir normas que afastem a dor dos homens e proporcionem o maior grau de felicidade ao maior número de pessoas ${ }^{65}$.

Os ensinamentos econômicos vinculados à Teoria Econômica do Direito sustentam a busca de valor semelhante. Individualmente, acredita que os indivíduos determinam suas condutas de maneira a aferir o maior proveito possível em todas as suas atividades - ganho esse que pode ser quantificado pecuniariamente, ainda que seja discutível a viabilidade de se determinar o grau de satisfação decorrente.

Coletivamente, propõe que os agentes públicos pautem-se pela racionalidade econômica na construção do Direito, de maneira a proporcionar a maximização da riqueza agregada, a riqueza da sociedade como um todo.

Adotada a concepção de que a ação individual - caracterizada pela racionalidade e estabelecida de modo teleológico - substitui, com ganhos, a idéia tradicional do homem médio da tradição jurídica, os autores estudados passam a fazer uso dos modelos construídos pela Teoria Econômica na observação da norma jurídica e sua relação com a sociedade. Ao supostamente conhecer melhor o homem e suas

\footnotetext{
62 POSNER, Economic Analysis of Law, p. 17-21.

63 Racionalidade enviesada ou bounded rationality é um termo usado para se referir "aos vários tipos de limitações cognitivas no processo em que muitas ou a maioria das pessoas tomam suas decisões, avaliam opções e se relacionam com a incerteza...” BIX, Brian. A Dictionary of Legal Theory. Oxford: Oxford University Press, 2004. p. 26.

64 Há excelentes obras dedicadas a esse problema. Entre elas, destaca-se o trabalho coletivo: PARISI, Francesco. SMITH, Vernon. (eds.) The Law and Economics of irrational behavior. Stanford: Stanford University Press, 2005.

${ }^{65}$ Semelhanças e discrepâncias entre a Teoria que agora se estuda e Utilitarismo serão delineados no Capílo 4.
} 
possíveis reações a incentivos, o Direito pode adequar seu conteúdo de maneira a que sua aplicação resulte em conseqüências sócio e economicamente desejáveis.

Os modelos de demanda e oferta de utilidades, bem como a descrição de seu equilíbrio de mercado - maximizador da utilidade ou riqueza - passam a ser usados pela Teoria Econômica do Direito simplesmente ao identificar essa utilidade não só com produtos e serviços, mas com qualquer vantagem ou anseio dos indivíduos ${ }^{66}$.

Nessa esteira, até mesmo a tutela jurídica conforma-se como uma espécie de mercadoria e sua produção se dá em um "mercado por normas" e o legislador, longe de seu tipo tradicional de onisciente e absolutamente racional, ganha a forma de um provedor, aos moldes da teoria da oferta microeconômica ${ }^{67}$.

\subsubsection{Qualificadoras da Teoria Econômica do Direito}

Caracterizando-se por seu conseqüencialismo, a Teoria Econômica do Direito teria muito em comum com abordagens mais pragmáticas ${ }^{68}$ a respeito de seu objeto. Medindo sua adequação através das conseqüências das intervenções que regras jurídicas causam na realidade socioeconômica, os meios - vale dizer, a forma - tem somente a importância como intermediário entre o reconhecimento da finalidade e a sua inserção no contexto social ${ }^{69}$.

De outro lado, pode-se dizer que essa teoria se constrói de maneira funcionalista, o que significa dizer que vê prioritariamente a imputação ao Direito de

\footnotetext{
${ }^{66}$ Maiores esclarecimentos sobre a maneira que os modelos econômicos são utilizados para descrever a realidade socioeconômica e compreender as condutas individuais são oferecidos no próximo Capítulo.

67 As implicações desses argumentos serão detalhadas no Capítulo 3.

${ }^{68}$ Por pragmatismo, compreende-se um método de abordagem da realidade que se perfaz mediante uso de ferramentais conceituais, postulados e concepções sem se deter acerca de seu valor filosófico último e sim com sua utilidade como instrumento discursivo e decisional. SPIRITO, Ugo. El pragmatismo em la Filosofía contemporánea. Buenos Aires: Losada, 1920. p. 47.

69 É preciso dizer que Posner nega sua qualificação como pragmático e até mesmo como utilitarista. Ao responder acusações de Dworkin que essas suas duas características o levariam a ser um anti-teórico e um relativista moral, alega que Dworkin chama de teoria apenas aquilo que é compatível com seus trabalhos e ainda explica que acredita no uso de preceitos morais globais como instrumentos adequados à manutenção de padrões de comportamento. POSNER, Richard. Conceptions of Legal "Theory": a response to Ronald Dworkin. Arizona State Law Journal. Nº. 29. 1997.
} 
funções sociais e contrasta, nessas suas proposições, com uma perspectiva mais abstrata ou metafísica do formalismo jurídico ${ }^{70}$.

Desse modo, além do uso de elementos cognitivos das ciências econômicas para explorar o que se denomina Direito, os autores em análise priorizam, em sua teoria a respeito do Direito, uma abordagem funcionalista e não estrutural. Eis o porquê, ainda que eventualmente tratado, o tema "O que é o Direito?" tem importância substancialmente menor nos debates de Law and Economics do que a pergunta "Para que serve o Direito?"71.

Nesse contexto, são objetos privilegiados dos autores de Law and Economics a produção do Direito, sua operacionalização prática, suas instâncias decisórias e sua capacidade de atingir fins eleitos pelos indivíduos que compõem a sociedade - preferencialmente, fins economicamente esclarecidos. Além disso, como já demonstrado, é possível determinar em seu interior a existência de parâmetros para se julgar a qualidade material do Direito, de mecanismos que guiem a decisão quanto ao conteúdo substancial das normas jurídicas, além de estudos apurados a respeito das conseqüências da incidência de regras jurídicas sobre a realidade socioeconômica.

São temas indubitavelmente ligados às preocupações tradicionais das ciências jurídicas, ainda que abordadas de maneira peculiar e, reitera-se, não com um foco estruturalista e sim funcional, o que, aliás, parece ser uma tendência crescente nas preocupações jurídicas expressadas no século $\mathrm{XX}^{72}$.

A adoção em pesquisas de temas jurídicos daquela figura individual que se fazia uso nos estudos econômicos passou a conformar um dos maiores conflitos e a mais importante novidade inseridos nos debates acadêmicos pelos autores de Law and Economics $^{73}$.

Trata-se, para alguns analistas, de uma revolução metodológica que levou os instrumentos da Economia para os temas de outras ciências sociais e, no Direito, teria

${ }^{70}$ Sobre o funcionalismo, BIX, Brian. A Dictionary of Legal Theory, p. 75.

71 Richard Posner chega a afirmar que a questão a respeito do que é o Direito não precisa ser perguntada ou respondida em função de sua pouca relevância em uma abordagem mais atrelada com as funções ou finalidades do Direito.POSNER, Law and Legal Theory in the UK and USA, p. 10.

72 Para outra concepção que compartilha a crença na transição entre modelos estruturalistas de teoria jurídica para modelos funcionalistas, BOBBIO, Norberto. Da Estrutura à Função: novos estudos de Teoria do Direito. Barueri: Manole, 2007.

73 HIRSCH, Werner. Law and Economics. 3rd. Ed. San Diego: Academic Press, 1999. 
ocasionado uma transformação irreversível na metodologia jurídica tradicional, antes vinculada a painéis formalistas de percepção de suas questões ${ }^{74}$.

É preciso pontuar que essa diferente aposta metodológica levou autores como Heath Pearson ${ }^{75}$ a considerar algumas abordagens de Law and Economics não somente uma nova corrente (um novo stream) das Ciências Econômicas, tampouco uma nova teoria jurídica, mas, sim, afirmar a instituição de uma nova Ciência. Uma "Nova Ciência dos Economistas"

Ao que parece, ele afirma que os economistas teriam - mais do que feito evoluir sua própria ciência - criado uma nova ao promover um salto tão grande com a inserção de investigação do aparato institucional como mais uma variável pertinente e não como algo dado, presumidamente estável, na construção de seus conhecimentos.

Essa nova ciência se diferenciaria da Economia e do Direito. Em relação à Economia, o distanciamento e a inovação se se dariam especialmente porque essa nova abordagem já não toma a estrutura institucional como dada, ignorável e estática. Principalmente em função dos trabalhos de Ronald Coase, essa nova ciência passaria a investigar o desenvolvimento e a mutação - quase mesmo em termos evolucionários das regras e características relevantes do ambiente econômico-social.

Já em relação ao Direito, Pearson dá ênfase aos novos estudos que propõem a perspectiva de que a substância do que se denomina Direito é conformada e modificada segundo elementos não jurídicos e, ainda que políticos, tratam-se de expressões políticas reduzidas à interação entre agentes com seus próprios interesses ${ }^{77}$.

Outro fator levantado por Pearson para afirmar a ruptura epistemológica é o fato de que, em que pese a continuidade do uso de modelos econômicos ideais da Economia Neoclássica, esses novos econômico-cientistas teriam como suas raízes teóricas não mais a Escola Clássica e seus legatários (mainstream), mas sim autores cujas preocupações iniciais eram as instituições - ainda que não explicitamente econômicas.

Para ele, os novos argumentos somente foram possíveis a partir de estudos que, em primeira análise, poderiam ser classificados amplamente apenas como

\footnotetext{
74 PARISI, Francesco. Positive, Normative and Functional Schools in Law and Economics.

75 PEARSON, Heath. Origins of Law and Economics: the economists' new science of Law. New York: Cambridge University Press, 1997. p. 6.

76 "Economists' new science", como se refere reiteradas vezes o autor.

77 O tema da nomogênese segundo a perspectiva de Law and Economics é tratada com mais vagar no Capítulo 3 do presente trabalho.
} 
de Ciências Sociais. Família, reputação pessoal e trabalho doméstico, por exemplo, e a interface dessas instituições sociais com a dinâmica da vida social e, em última análise, dos mercados e dos direitos ${ }^{78}$.

Essa grande aposta metodológica, no entanto, não resta livre de críticas. Para McCloskey, ela se assentaria em uma falácia ${ }^{79}$.

Segundo esse autor, o grande desenvolvimento que Law and Economics experimentou entre os interessados em estudar regras jurídicas teria se dado em razão da crença de que o Direito - e seus usuais métodos formais - careceria de qualquer cientificidade. As teorias do Direito que antecederam a Análise Econômica não seriam satisfatórias para aqueles que demandam maior positividade epistemológica de tão importante instituição social.

A Economia, de outro lado, teria conseguido prosperar mediante o emprego de métodos mais seguros, de maior cientificidade, uma vez que mais semelhantes aos das ciências naturais. Essa crença, alerta o autor, não seria verdade.

Esclarece McCloskey que Economia, tanto quanto o Direito, progrediu sobre argumentos igualmente retóricos e não estritamente científicos. Suas presunções e os modelos que elas tornam possíveis - não tem sequer a pretensão de explicar a realidade. Seriam, ao contrário, construções meramente retóricas da realidade: fariam, portanto, todo sentido como discurso, mas nada revelariam da realidade.

Além disso, o uso desses conhecimentos econômicos - por si só distantes de qualquer verdade sobre o real - teriam sido mal utilizados pelos autores de Law and Economics. Ao se referir a trechos do livro Economic Analysis of Law de Richard Posner, McClowskey afirma:

O argumento na passagem [citada pelo autor anteriormente] está corrompido em parte pelo uso equivocado do vocabulário econômico: 'alocar', 'maximizar', 'valor' e 'escassez' são termos técnicos em Economia, com definições precisas, mas aqui [na referida obra de Posner] são também utilizados em um senso mais abrangente, de modo a evocar uma concepção de poder científico, para reclamar-se como precisos sem de fato sê-lo. ${ }^{80}$

\footnotetext{
78 Para uma investigação mais detalhada desse histórico muito detalhado e mais atípico a respeito da Law and Economics, vide PEARSON, Origins of Law and Economics, p. 7 e seguintes.

79 MCCLOSKEY, Donald N. The rhetoric of Law and Economics. Michigan Law Review. Vol. 86. N. 4. Fevereiro de 1988. p. 757 e seguintes.

80 Tradução livre. MCCLOSKEY, The rhetoric of Law and Economics. p. 761.
} 
De toda forma, apesar das críticas possíveis a respeito de suas assunções e métodos, não se descaracteriza a peculiaridade que a Teoria Econômica do Direito traz ao examinar seu objeto. Ao adotar uma postura expressamente conseqüencialista e funcionalista, desloca o debate jurídico da forma que as regras jurídicas tomam para o tema das capacidades que o Direito pode e deve desempenhar perante a sociedade em que se insere. Não parece se configurar - convém esclarecer - de uma abordagem jurídica vinculável facilmente ao jusnaturalismo, especialmente pela presença do argumento de que a adequação econômica do Direito não é pré-condição para sua existência como tal, mas apenas a avaliação de sua qualidade sócio-econômica.

Ainda assim, seja em sua análise descritiva ou em seu mote prescricional, essa possível teoria inova ao propor a eficiência como um valor a guiar e avaliar o desenvolvimento e aplicação do Direito. Resta agora saber o que seus autores chamam de "eficiência". 


\section{FUNDAMENTOS DA TEORIA ECONÔMICA DO DIREITO}

Antes que se definam as possíveis categorias de eficiências, é preciso conhecer os modelos econômicos que são pressupostos a sua compreensão.

Para tanto, será preciso apresentar os elementos de teoria econômica que são necessários ao desenvolvimento do raciocínio microeconômico e demonstrar as relações que podem estabelecer entre si ou como mecanismos gerais de decisão racional. Nessa instrução preliminar, serão delineados os conceitos de maximização da utilidade, os de demanda e a oferta, o equilíbrio ideal entre essas duas funções, além de outros elementos que se conjugam a essas concepções.

Esses conhecimentos conformarão o instrumental básico com o qual, como se pretende demonstrar no presente trabalho, erige-se a possibilidade do cálculo econômico e até mesmo moral a respeito da adequação do Direito. Desse modo, ainda que as informações apresentadas a seguir sejam elementares em seu contexto original nas ciências econômicas - são reproduzidas a fim de estabelecer os pressupostos conceituais e metodológicos para uma abordagem jurídico-filosófica da eficiência.

Ademais, tem-se por finalidade traçar os primeiros apontamentos a fim de demonstrar como tais modelos apresentam em si a qualidade de gestores racionais de recursos em sentido amplo, conformando um mecanismo de decisão social calcado no consenso presumível comum às transações voluntárias. Ou seja, pretende-se apresentar os modelos econômicos e, revisitando-os de uma perspectiva filosófica, investigar que construções conceituais foram necessárias para que se tornassem, para os teóricos da Análise Econômica do Direito, adequados referenciais para a tomada de decisões práticas.

Preliminarmente, é preciso observar que a Teoria Econômica Neoclássica, da qual parte-se na busca por demonstrar como modelos econômicos podem guiar decisões políticas e jurídicas, têm como pressuposto o axioma de que o indivíduo busca sempre satisfazer seus interesses. Trata-se de movimento dinâmico através do qual as pessoas sempre ansiarão por mais satisfação.

De maneira bastante emblemática, tem-se que o próprio indivíduo - e não o Estado em seu nome - como o ente mais bem capacitado para definir que bens prefere 
e qual o grau de importância que dá a esse desejo, sendo possível determinar a ordem de preferência, para um mesmo agente, entre vários bens ${ }^{81}$.

No entanto, como o elenco de preferências decorre da subjetividade dos indivíduos, é muito discutível a possibilidade de que se avalie a relação de utilidade intersubjetiva, ou seja, a princípio é impraticável a atividade de se examinar se um mesmo bem gera mais satisfação mais para um ou outro indivíduo. Essa subjetividade relacionada à utilidade terá grande impacto na mensurabilidade da maximização e figura como uma das razões pelas quais há autores que prefiram a riqueza - e não a utilidade como unidade comparativa, como se demonstrará.

Trata-se de um alerta da doutrina econômica ${ }^{82}$. Dada a subjetividade do gozo das utilidades, é possível verificar a ordem de preferência entre bens, mas não o vigor do desejo sobre eles. No entanto, como se verificará, as relações comutativas, especialmente via pecuniária, podem ser um indício objetivo do quanto um agente valora um bem e permite, de modo aproximado, algum exame intersubjetivo quanto às utilidades. Isso porque o anseio por gozar de uma satisfação pode melhor ser expresso quando, em face de um mercado real ou ao menos hipotético, o indivíduo é capaz de apontar qual o montante de pecúnia está disposto a despender para alcançar a utilidade. A moeda, nesse caso, objetiva um critério de comparação entre o valor subjetivo que uma mesma pessoa dá a bens diferenciados e torna capaz de aferir a proporção do desejo sobre os bens, e não somente elencá-los em ordem de vigor do anseio. Não se trata, por suposto, de uma medida exata da satisfação e nem permite comparações precisas entre indivíduos, mas parece ser uma aproximação razoável ${ }^{83}$.

Segundo a dogmática da Escola Econômica Neoclássica, a demanda individual é determinada pela quantidade que um indivíduo está disposto a adquirir de um dado produto a um dado valor em determinado período de tempo, o que não se

${ }^{81}$ COOTER, Robert. ULEN, Thomas. Derecho y Economía. Fondo de Cultura Económica: Cidade do México, 1997., p. 24-35.

82 "Uma conseqüência importante da subjetividade das preferências individuais é que os economistas não têm nenhum método aceitado para comparar o vigor das preferências dos indivíduos." COOTER, Derecho y Economía, p. 33.

83 Calabresi expressa sua desconfiança sobre a crença de que o valor pecuniário possa significar um meio objetivo com o qual possa haver comparação entre o valor que diferentes pessoas, com preferências distintas, possam dar a qualquer recurso. Para ele, não parece haver qualquer identidade entre a satisfação que alguém rico e outro pobre podem extrair da detenção de um dólar. CALABRESI, Guido. An Exchange: about Law and Economics: a letter to Ronald Dworkin. Hofstra Law Review, vol. 8, p. 553-562, 1979-1980. 
identifica necessariamente com o volume que o indivíduo efetivamente vem a comprar no mercado ${ }^{84}$.

Nessa esteira, o aumento de preço de um bem, e sua correspondente utilidade, tende a diminuir o seu consumo, seja porque as pessoas vão parar de adquiri-la ou então porque passarão a dar preferência a um produto substituto que tenha mantido seu preço estável. Fato é que a compra daquele bem diminuirá.

Uma vez conhecido o conceito de demanda individual por um determinado produto, bastaria, para a Escola Neoclássica, somar a todas as demandas individuais a fim de se obter o volume demandado de certo produto por toda a sociedade, configurando-se, assim, a demanda de um mercado específico.

É preciso atentar para o fato de que a teoria se estabelece segundo a concepção de que o pagamento que será oferecido em troca do bem ou utilidade não precisa se constituir em pecúnia, nem mesmo em algo material, mas simplesmente precisa revelar o que o indivíduo está disposto a deixar de consumir de outros bens ou utilidades a fim de adquirir aquele em questão.

Ao somar as diversas demandas sociais pelos mais variados produtos em todos os mercados, obtém-se a demanda total da sociedade por bens e serviços. Essa é a demanda agregada de uma dada sociedade. Ressalta-se, desde logo, que o que a teoria microeconômica denomina "bens" e "serviços" pode ter seu significado ampliado ao pondo de incluir quaisquer vantagens, satisfações físicas ou morais, de que podem gozar os indivíduos. É dessa premissa inclusiva e ampliadora de que partem alguns dos autores vinculados à Análise Econômica do Direito para constituir uma teoria moral ao reempregar modelos econômicos como referências para decisões racionais.

O conhecimento a respeito das curvas de demanda possibilita a verificação do que se denomina "excedente do consumidor". Baseando-se no fato de que cada consumidor valora diferentemente cada mercadoria e que todos a adquirem a um mesmo preço, o de mercado, para cada consumidor se definirá um excedente valorativo, que é a diferença entre o que o preço que o consumidor estava disposto a pagar e o preço em que ele efetivou a aquisição ${ }^{85}$.

\footnotetext{
${ }^{84}$ MONTORO FILHO In: PINHO, Diva Benevides. VASCONCELLOS, Marco Antonio S. de. (orgs.) Manual de economia. $5^{\text {a }}$. Ed. São Paulo: Saraiva, 2004. p. 133.

${ }^{85}$ PINDYCK, Robert S. RUBINFEL, Daniel L. Microeconomia. 5a. ed. São Paulo: Prentice Hall, 2002. p. 123.
} 
Quando somados os excedentes de todos os consumidores, encontra-se o excedente agregado dos consumidores, que será importante ferramenta na construção dos postulados que são investigados no presente estudo.

A configuração da curva de demanda por qualquer produto é sempre em razão de seu preço, mas ela também pode sofrer alterações em razão do valor cobrado por produtos substitutos e da renda do consumidor, dentre outros fatores, sofrendo deslocamentos. Isso ocorre porque a curva de demanda nem sempre é fixa e pode sofrer deslocamentos. Tome-se um produto hipotético $\alpha$, do qual demanda-se 100 unidades ao preço de $X$ em dada conjuntura. Em face de uma substancial modificação no nível de renda dos consumidores, esse mesmo bem será demandado em quantidade diversa a um mesmo preço. Se a renda média dos consumidores triplicar no decurso de tempo, é possível que a demanda pelo bem $\alpha$ também cresça e, pelo mesmo preço de $X$, a demanda nessa nova circunstância seja de 200 unidades.

O reconhecimento da contingência da configuração de curvas de demanda é capaz de esclarecer que os elementos exógenos são capazes de redefinir o arranjo de demandas, ou seja, há mutabilidade das preferências sociais em face de alterações substanciais na conjuntura social. Novamente, um movimento argumentativo inclusor pode fazer uso desses mecanismos de mutação das preferências no tempo para explicar porque diferenciados níveis de tutela jurídica são exigidos por diferentes grupos sociais ao longo do tempo. Com a alteração no cenário sócio-econômico, os ganhos possíveis se multiplicam e, igualmente, aumentam os anseios por apoio estatal.

Para uma teoria econômica da decisão social, isso é muito relevante já que elucida o problema da variabilidade dos anseios agregados de acordo com o tempo, o espaço e o grau de desenvolvimento social.

Até o momento, manteve-se o foco na teoria da demanda. No entanto, para a compreensão dos mercados, é fundamental que se estude também a teoria da oferta, que terá relevância maior no que se refere à eficiência produtiva.

A curva de oferta descreve a "quantidade de mercadoria que os produtores estão dispostos a vender a determinado preço, mantendo-se constantes quaisquer fatores que possam afetar a quantidade ofertada" ${ }^{\prime 86}$.

A oferta configura-se de maneira a que, quanto maior o valor de mercado pago por um determinado bem, maior será a quantidade que seu produtor terá interesse

\footnotetext{
${ }^{86}$ PINDYCK, Microeconomia, p. 123.
} 
em ofertar. De maneira mais ampla, a oferta de bens em um dado mercado tende a crescer em razão do aumento do preço dessa utilidade.

Tomando aquela mesma utilidade $\alpha$ como exemplo, tem-se que, ao preço de $X$, as pessoas estão dispostas a produzir e vender uma quantidade de 100 unidades e ao preço de $2 X$ os incentivos para a produção aumentem e, nesse preço mais elevado, os ofertantes estejam dispostos a oferecer um total de 200 unidades.

No entanto, também é possível que - em mesmo nível de preços - fatores como a redução dos custos de produção ocasionem um deslocamento da curva de oferta. Caso o investimento necessário para a produção de um dado bem diminua, elevam-se os incentivos para que o produtor, em mesma faixa de preço de mercado, ofereça mais bens, pois a queda nos custos aumenta seu lucro econômico em relação à situação anterior. Assim, dada uma queda significativa nos custos de produção de $\alpha$, a um mesmo preço de mercado em $X$, será conveniente aos produtores a oferta de 150 unidades - ao contrário de 100, já que, em razão da eficiência produtiva ou da queda dos custos de transação naquele mercado, o custo marginal do bem cai e, portanto, torna-se rentável a oferta de mais unidades, até que a receita marginal iguale-se novamente com o custo, estalecendo-se uma situação ideal.

Assim apresentadas as teorias da oferta e da demanda separadamente, é preciso verificar como se dá o seu relacionamento nos mercados ideais, cuja configuração é um parâmetro de comparação razoável com mercados reais ou hipotéticos.

Em uma situação de mercado, as curvas de oferta e demanda se encontram em um dado ponto. Trata-se do preço de equilíbrio, em que a quantidade ofertada identifica-se com a demanda.

A tendência que leva o preço a essa situação de equilíbrio é denominada Mecanismo de Mercado e, basicamente, traduz-se no fato de que enquanto a procura por bens estiver, a um determinado nível de preços, abaixo da demanda normal para o esse valor, há a tendência de que mais consumidores passem a buscar tais utilidades e a procura por tais bens cresça até atingir a demanda inerente ao nível de preço dado. De outro lado, enquanto a oferta de um produto a determinado preço não estiver completada, ela seguirá crescendo até que alcance o montante que, ao preço de equilíbrio, os ofertantes estão dispostos a vender ${ }^{87}$.

${ }^{87}$ PINDYCK, Microeconomia, p. 23. 
Isso decorre da busca individual por maximizar a satisfação. Pelo lado da demanda, a um nível de preços, um número previsível de produtos será desejado, pois o valor que os consumidores, de maneira geral, dão ao bem é igual ou maior do que o valor que é cobrado por ele. Pela vertente da oferta, haverá o aludido crescimento, pois os fornecedores verão interesse em aumentar o montante de utilidades ofertadas até o ponto em que disponibilizar uma unidade a mais seja indiferente ou traga prejuízos.

Críticas podem ser levantadas a respeito da verdade e funcionalidade de tais modelos e limites quanto a sua aplicabilidade são cabíveis, no entanto, eles são capazes de se conservar como instrumento adequado de compreensão da realidade e, além disso, de se tornar uma ferramenta razoável para previsão de cenários ${ }^{88}$.

Apresentados esses conceitos fundamentais a respeito da construção do pensamento sobre a realidade socioeconômica, segue-se o estudo de maneira a demonstrar quais são os tipos de eficiências presentes no pensamento econômico.

\subsection{Eficiência produtiva}

Eficiência produtiva pode ser definida, de maneira simplificada, como o melhor uso dos insumos no processo de produção de bens e serviços, dadas as restrições aplicáveis.

Os insumos são todos os elementos necessários para o processamento de utilidades. É possível identificar uma série desses elementos, mas, para efeitos teóricos, os mais relevantes são o capital e trabalho, amplamente considerados. Assim, haverá eficiência quando, com a menor quantidade de insumos, for produzida uma mesma quantidade de bens ou então quando, com um volume constante de capital e trabalho, mais bens forem produzidos.

Dada a constância da qualidade dos insumos, o grau de eficiência produtiva decorre da maneira em que capital e trabalho são combinados, relação essa

\footnotetext{
${ }^{88}$ Aliam-se às críticas sobre a aplicabilidade de tais modelos idéias inúmeras escolas econômicas. A título ilustrativo, é possível citar a Economia dos Custos de Transação, que revela que há entraves econômicos ao funcionamento perfeito de mercados que são idiossincráticos à sua constituição, tais como custos para estabelecer o contato entre demandante e fornecedor, custos relacionados à negociação e ao cumprimento do acordado.
} 
descrita como uma função de produção ${ }^{89}$. A maneira que se dá essa combinação costuma receber a denominação genérica de "tecnologia".

Assim, basicamente, é o grau de desenvolvimento tecnológico em determinado setor que define quão eficiente será a produção de utilidades em seu mercado correlato.

Esses dois insumos também podem ser expressos como custos para a produção de uma dada utilidade. Nesse sentido, é possível também descrever a eficiência produtiva como a produção de um bem ao menor custo possível.

Ao identificar esses insumos com os custos para se produzir cada produto ou oferecer um serviço, é possível também explorar a relação existente entre a quantidade produzida e os recursos utilizados em seu processamento. Disso derivam as concepções de custo médio, soma dos custos totais dividida entre a quantidade de utilidades desenvolvidas, e custo marginal, o dispêndio necessário para que se produza uma unidade a mais de determinado bem.

Há produtos cujo aumento de produção minora o custo marginal. Essas situações são denominadas "economias de escala". Em tais circunstâncias, configura-se a tendência de que uma situação ideal de mercado atomizado seja menos eficiente que a presença de um monopolista que, ao produzir em larga escala, reduz significativamente o custo unitário do bem ou serviço e seria capaz de ofertá-lo a menor preço ${ }^{90}$.

Os denominados monopólios naturais são exemplos de como, dadas certas características próprias a um setor, o monopólio pode apresentar maior eficiência produtiva do que o mercado ideal.

Até o momento, demonstrou-se como a produção de um dado bem ou serviço exige insumos que, combinados em uma função produtiva, pode ser avaliada em sua eficiência nos termos da relação de custos e utilidades. Esse modelo refere-se somente a uma análise parcial, capaz de interpretar o arranjo produtivo de apenas um produto isoladamente.

Mas, em sociedade, a aplicação dos recursos produtivos com a finalidade de oferecimento, em mercado, de bens e serviços se estabelece de maneira cruzada, ou seja, a opção pelo aumento da produção de um determinado produto reflete-se,

\footnotetext{
89 "Relação entre a quantidade de insumos empregados para obter um bem e a quantidade de bem produzida" MANKIW, N. Gregory. Introdução à economia: princípios de micro e macro economia. $2^{\mathrm{a}}$. Ed. Rio de Janeiro: Elsevier, 2001. p. 273.

90 Por suposto, tal situação exigiria a benevolência do monopolista, já que ele não teria incentivos para baixar o preço do produto até a proximidade do custo marginal.
} 
diretamente, na diminuição da produção de uma utilidade que tenha por insumo os mesmos recursos. Como capital e trabalho são recursos limitados importantes no processamento de quaisquer mercadorias, o seu uso na produção de qualquer bem tende a refletir-se na produção de outro, seja porque os torna menos disponíveis ou então porque, dada a maior procura, os seus preços se elevam. O Direito, é preciso lembrar, tem fundamental importância na configuração dos mercados de trabalho e capital, pelo que podem influenciar toda uma realidade produtiva.

Nesses termos mais globais, será considerada eficiente a conjuntura de produção em que não for possível produzir mais de uma determinada utilidade sem que seja afetada a produção de outra ${ }^{91}$.

Para a construção dos referenciais para a decisão racional fundada em conhecimentos econômicos - teleologicamente, portanto - como se busca na Análise Econômica do Direito, a concepção de eficiência produtiva elucida que, em face da realidade com recursos escassos, é fundamental que os indivíduos em sociedade sejam capazes de definir o melhor arranjo produtivo social de maneira a ofertar o maior volume de bens e serviços - utilidades - com a menor quantidade relativa de insumos, que assim poderão ser liberados à produção de outras utilidades ou oferta ampliada das mesmas, de acordo com as preferências sociais ou, em outros termos, individuais agregadas.

A eficiência produtiva, ainda que tenha essa grande importância na Teoria Econômica, não é a modalidade de eficiência com a qual a Análise Econômica do Direito se ocupa prioritariamente, pois a constituição de um arranjo produtivo adequado também se dá em função da alocação de bens de capital. Ou seja, é mais usual que em seus estudos se voltem mais a problemas alocativos e estes indiretamente toquem a questão da produtividade.

De toda forma, o Direito pode ser bastante significativo na criação de ambientes institucionais ${ }^{92}$ que promovam melhorias no fator de produção. Além disso, intervenções jurídicas podem provocar oscilações diretas e indiretas de preços dos insumos, alterando substancialmente seu custo produtivo e, portanto, modificando o

\footnotetext{
91 "Uma determinada alocação de insumos para o processo produtivo é considerada tecnicamente eficiente se a produção de uma mercadoria não puder ser aumentada sem que ocorra uma diminuição da quantidade produzida de outra mercadoria." PYNDICK, Microeconomia, p. 523.

${ }^{92}$ Por "ambientes institucionais" são tratados aqui os elementos públicos e privados capazes de estabelecer as "regras do jogo" da Economia e referenciar a conduta dos agentes de mercado. BUSCAGLIA, Edgardo. RATLIFF, William. Law and Economics in developing countries. Stanford: Hoover, 2000. p. 2 e seguintes.
} 
preço final e deslocando o ponto de equilíbrio do mercado. Em tal caso, de um lado configura-se certa ineficiência produtiva comparada temporal - em relação ao estado anterior - e de outro lado em uma comparação espacial - em relação a localidades em que não vige essas regras jurídicas.

Além disso, a modificação dos valores de equilíbrio de mercado altera a alocação de utilidades entre consumidores e ofertantes. Neste senso, também é importante sua análise, mas deve se manter em foco o fato de que se trata de uma questão de alocação e não de eficiência produtiva ${ }^{93}$.

No que se refere especificamente à eficiência da função de produção de longo prazo, como ela é uma decorrência do nível de evolução da tecnologia de combinação de recursos, o Direito tem apenas mediata influência, na medida em que configura a realidade institucional em que o empreendimento de pesquisas se realiza, sendo capaz, inclusive, de desenvolver estímulos adequados para que inovações sejam alcançadas e bem utilizadas. Instituir um cenário em que existam incentivos e segurança para a inversão em novas tecnologias pode promover, em médio e longo prazo, maior eficiência produtiva comparada ${ }^{94}$.

\subsection{Eficiência alocativa}

A eficiência alocativa fica configurada quando um recurso é colocado nas mãos daquele que lhe dá maior valor. Isso significa não só dizer que as utilidades devem estar junto àqueles que subjetivamente lhes imputam maior importância, mas também que os recursos devem permanecer sob a tutela daqueles que são capazes de fazê-los frutificar de maneira mais acentuada.

Em um contexto teórico ortodoxo, a fim de atingir a primeira acepção de eficiência alocativa apresentada, percebe-se que basta que o Direito estabeleça uma clara disposição a respeito dos direitos e propriedade e, mais, disponibilize um confiável

93 Em outros termos, pode se tratar de um problema de transferência de riqueza - ou utilidade - e não de modificação agregada da situação econômica dos agentes.

94 O tema da otimização produtiva que tenha sua origem no desenvolvimento tecnológico leva a denominação de Eficiência Dinâmica e é controversa a possibilidade de estabelecer modelos econômicos a respeito dessa elementar. Dada a polêmica dentro da própria ciência econômica, deixa-se aqui de tratá-lo com maior profundidade. 
sistema de trocas através da instituição de uma estrutura normativa que force o cumprimento obrigacional para que, mediante as transações privadas, os bens migrem daqueles que lhes dão menor valor para aqueles que lhe estimam mais.

Uma relação simples de venda e compra pode servir de exemplo. Se o indivíduo A possui um bem $\alpha$ e está disposto a vendê-lo até por $X$ e o indivíduo B está a procura da mesma utilidade e por ela pagaria até $2 X$, o bem migrará das mãos de A para as de $\mathrm{B}$, sendo, pois, alocado àquele que lhe dá maior valor, desde que não existam custos que inviabilizem a transação.

É preciso, então, verificar que custos são esses que poderiam obstar a transação.

Os custos de transação são, basicamente, de três categorias. São aqueles despendidos na busca recíproca que se realiza entre o comprador e o vendedor, aqueles relacionados à própria negociação e, por fim, aqueles que dizem respeito ao monitoramento do acordado a fim de que a obrigação seja efetuada.

Quando as obrigações realizam-se imediatamente e não em tempo diferido, os custos de monitoramento são baixos e significantes apenas se qualquer das partes deixar de entregar, no momento da transação, o que se comprometeu, o que o torna em execução em tempo diferido, passando a incorrer nos custos dessa modalidade.

Os custos de negociação no caso em tela são também baixos, já que há uma convergência, inclusive no que diz respeito a valores, entre o ofertante e o demandante, motivo pelo qual é possível crer que serão gastos pouco tempo e baixos recursos durante as negociações.

No que se refere aos custos de rastreamento, eles serão baixos desde que o bem $\alpha$ seja ordinário, seu ofertante de fácil acesso e não trouxer peculiaridades que possam dificultar sua busca.

No caso em análise, dados os baixos custos de transação, o bem poderia ser negociado $1,5 X$ e ambos, ofertante e demandante, se aproveitariam de um excedente de $0,5 X$ cada. Além disso, o bem, que alocado nas mãos de A tinha um valor de $X$, passou às mãos de $\mathrm{B}$, que lhe outorga valor de $2 X$. A transação, por si só, foi capaz de aumentar a riqueza agregada em $X$, exatamente no mesmo montante que se acresceu valor ao bem.

Tomando o segundo viés como exemplo, é possível traçar um caso um pouco mais complexo, mas que também revela mais sobre a lógica envolvida no debate. 
Nesta questão, é possível inclusive traçar uma possível relação entre a eficiência alocativa e a eficiência produtiva.

Para tanto, imagine-se que a empresa A possua uma planta fabril $\beta$ e está prestes a fechá-la, pois, com seus métodos de produção, não consegue desenvolver mais do que mil unidades por mês, o que aumenta o custo médio de seus produtos e, conseqüentemente, a torna pouco competitiva.

No entanto, a empresa B, do mesmo setor, é detentora de um conhecimento privilegiado com o qual, com semelhantes instalações produtivas, é capaz de produzir o dobro de unidades por mês e reduzir sensivelmente os custo médio de seus produtos.

Pressupondo-se que se trata de um mercado em que nenhum dos agentes possua poder de mercado relevante ${ }^{95}$ e dada uma circunstância de baixos custos de transação, a planta fabril $\beta$ seja vendida por A para a empresa $B$, nas mãos de quem o bem tem maior valia, já que esta segunda entidade é capaz de extrair dele maiores ganhos.

Assim, configura-se a razão pela qual a escola econômica neoclássica e os autores da Teoria Econômica do Direito dão tanta importância à liberdade de gestão de bens em um mercado, pois seu mecanismo, quando em adequado funcionamento, é considerado o melhor alocador de recursos sociais, sejam produtos, serviços ou, de maneira bastante ampliada, quaisquer utilidades.

Sem dúvidas, trata-se de uma estrutura que conduz a uma maior valorização dos recursos, por definição escassos, disponíveis para a sociedade como um todo. Se for possível extrair deles os maiores frutos, não há motivos para que isso seja obstado, já que é do interesse geral que assim o seja, não havendo quem, ao menos a princípio, se estabeleça racionalmente contra a majoração da riqueza social.

\footnotetext{
95 Nenhum dos produtores envolvidos possui parcela significativa do mercado que lhe trouxesse a possibilidade de, com suas condutas, afetar o equilíbrio de mercado. No Brasil, regra geral é de que inexistência de parcela do mercado acima de $20 \%$ dá indicações da que não há detentores de poder de mercado, salvo exceções.
} 


\subsubsection{Critério Paretiano}

Considerar a possibilidade de que a maximização da riqueza ou utilidade seja um critério objetivo e bastante conveniente a ser buscado através do Direito, não é suficiente para findar o debate a respeito dos mecanismos de aferição dessa majoração almejada.

É preciso verificar quais os meios que a Teoria Econômica disponibiliza para tanto. A escolha de um critério para a avaliação da adequação de qualquer norma é fundamental para que, então, seja possível aferir se - e quando - a intervenção do Direito nas relações sociais é economicamente conveniente.

O problema enfrentado pela teoria econômica e filosofia nesse aspecto é encontrar um meio adequado de "agregar as preferências individuais em preferências sociais" $" 96$.

Bentham, e o pensamento utilitário clássico ${ }^{97}$, já havia estabelecido, ao menos em teoria, uma maneira pela qual seria possível a somatória das utilidades individuais e, dada uma sociedade em determinado tempo, haveria apenas um ponto ótimo em que o agregado seria maximizado, implantando somente a dúvida acerca de qual seria esse ponto.

Por sua vez, o que se construiu a respeito do critério de Pareto é capaz de apontar a possibilidade de um grande número de alocações em que se fazem presentes os elementos que permitem afirmar o alcance da eficiência ${ }^{98}$.

É possível afirmar que ponto de vista da aceitação racional ampla, o critério mais sensível de eficiência é o de Pareto. Basicamente, de acordo com seu corolário, uma determinada alocação de recursos é eficiente quando é impossível melhorar a situação de qualquer das partes envolvidas direta - ou indiretamente - sem que, para tanto, a de uma parte seja piorada.

Nesse mesmo sentido, uma decisão que efetue a realocação de recursos é eficiente somente quando se estabelece uma situação em que todas as partes afetadas aproveitaram melhora de condição, sem que ninguém tenha tido qualquer piora. Dessa

\footnotetext{
96 PARISI, Positive, Normative and Functional Schools in Law and Economics, p. 13.

97 As ponderações da Escola Utilitária Clássica são mais detidamente tratadas no Capítulo final do presente trabalho.

98 CIRILLO, Renato. The economics of Vilfred Pareto. London: Billing \& Sons, 1979. p. 43.
} 
maneira, também será atendido caso haja a melhora de ao menos um e todos os demais afetados tenham permanecido em situação estável. Trata-se da definição da Superioridade de Pareto, que compara duas alocações distintas e é capaz de apontar qual é melhor sob o ponto de vista desse critério.

$\mathrm{O}$ critério paretiano é tido como o mais exigente no que se refere à asseguração de que, uma vez seguido, nenhuma atitude terá efeitos negativos. Assim, intervenções que satisfaçam as disposições paretianas não podem ser apontadas, por qualquer parte, como geradoras de efeito negativo, sem que se atente contra o pressuposto da racionalidade dos indivíduos.

Em suma, uma transação pareto-superior é aquela em que ao menos uma das partes passa a figurar em melhor condição (better off) e nenhuma delas fica em pior estado (worse off). A superioridade de Pareto constitui no ganho unânime de todos os envolvidos ou na manutenção do status de alguns deles, não havendo qualquer externalidade negativa resultantes da transação. Será ainda pareto-ótima se nenhuma outra realocação pode ser feita sem que se desconfigure a adequação paretiana.

A conexão entre situações alocaticas paretianas e os mercados é tema freqüente de debates. A princípio, as transações de mercado são sempre feitas de maneira estabelecer um resultado pareto-superior (em relação à situação anterior) e, portanto, o ponto de equilíbrio de um mercado seria pareto-ótimo. Entretanto, há estudos que demonstram que isso pode nem sempre se efetivar, seja em razão dos custos transacionais, seja por deformações da racionalidade, como a circularidade entre preferências, que podem causar distorções na aferição da maximização ${ }^{99}$.

Ainda assim, apesar de sua fama e de sua singular vantagem perante qualquer outra acepção, a teoria de Pareto é pouco aplicável, pois a maioria das transações ou mudanças normativas acabam por afetar negativamente qualquer das partes ou terceiros, possivelmente gerando a esses prejuízos, mesmo que indiretos. Desse modo, para uma análise razoável de qualquer relação efetuada no seio social, o parâmetro de eficiência não pode ser o único instrumento utilizado.

É preciso esclarecer que o critério paretiano é levantado por algum autores $^{100}$ como parâmetro capaz não só para avaliar transições comutativas ou

\footnotetext{
99 COLEMAN, Jules. Efficiency, utility and wealth maximization. Hofstra Law Review, vol. 8,p. 509544, 1979-1980.

${ }^{100}$ BUCHANAN, Allen. Etica, efficienza, mercato. Napoli: Liguori Editore, 1992. p. 17.
} 
alocativas mas, como decorrência desta primeira capacidade, ideal para avaliar movimentos distributivos, além de apto a apreciar a adequação de arranjos produtivos.

O critério de Pareto, no entanto, padeceria de uma falha. Seu método de comparação entre circunstâncias seria insensível às diferenças interindividuais de utilidade, já que - quase uma unanimidade dentre os teóricos econômicos - não é possível que o tomador da decisão avalie o grau de satisfação ímpar que um bem causa a cada pessoa. Sem conhecer o efeito que qualquer realocação gera na satisfação das pessoas afetadas, não seria viável reconhecer o atendimento ao juízo paretiano.

Ainda assim, o Critério de Pareto não demanda - ao contrário do se verifica no Utilitarismo Clássico - a comparação, tida como imponderável, da utilidade entre diferentes pessoas. Demanda, tão somente, a comparação do grau de satisfação de uma pessoa antes e depois da modificação. Ou seja, não se vale de comparativos intersubjetivos, mas tão somente intertemporais ${ }^{101}$.

É preciso pontuar outra limitação ao ideal paretiano. Ele aponta como eficiente a alocação social ótima quando parte-se de uma situação prévia distributiva igualmente ótima, já que, se o status anterior for viciado - e tiver alocado bens a quem não lhes dá valor - poderá ser difícil a realocação a uma situação ideal sem que qualquer dos afetados veja-se prejudicado. Outra crítica possível é a de que só é capaz de promover avaliações ordinais de preferências, já que não possui capacidade de se sensibilizar pelos níveis cardinais de preferência (intensidade da preferência) ${ }^{102}$.

\subsubsection{Critérios compensatórios}

Como uma alternativa ao Critério de Pareto, tantas vezes impraticável pela rigidez de suas condições e pelo imenso volume de informações que demanda ${ }^{103}$, o critério Kaldor-Hicks se configura como alternativa de maior viabilidade para guiar as interferências jurídicas na realidade socioeconômica ou, de maneira mais ampla, abalizar a decisão racional. Nesse critério, a eficiência pode restar caracterizada ainda que da

\footnotetext{
${ }^{101}$ ZERBE JR., Economic efficiency in Law and Economics, p. 2

102 PARISI, Positive, Normative and Functional Schools in Law and Economics, p. 13.

103 GONZALEZ-QUIJANO, Francisco. La curva de Pareto y la distribuición de la riqueza. Madrid: Colegio de Ingenieros de Caminos y Puertos, 1966. p. 16.
} 
relação resulte dano a terceiros ou que, a princípio, qualquer das partes envolvidas apresente uma piora em sua situação. Esses prejuízos devem, no entanto, ser compensados.

Essa compensação pode ser efetiva ou meramente em termos agregados. Neste último caso, basta que os ganhos auferidos por um sejam maiores que os prejuízos observados por outros para que, em sua somatória positiva, seja reconhecida a maximização da utilidade ou riqueza da sociedade e, em decorrência disso, seja satisfeito esse critério de eficiência.

A princípio, portanto, satisfaz esse critério a realocação que, apesar de gerar malefícios a alguém dentre os envolvidos, gera aos demais um benefício superior a essa perda. Suficiente, portanto, que haja a potencialidade da compensação, ou seja, a possibilidade de que aqueles que tiveram ganhos extraordinários os dividam com os prejudicados a fim de garantir a estabilidade - e não piora - da situação destes. Em função disso, o Critério Kaldor-Hicks também recebe a denominação de "Pareto Potencial" 104 .

No entanto, um avanço no teorema compensatório leva à exigência de que, para que se outorgue a qualificadora de eficiente para qualquer transação ou intervenção, os ganhos excedentes sejam utilizados na indenização efetiva daqueles que sofreram perdas. Nessa concepção, não é a mera externalidade negativa que caracteriza a ineficiência, mas sim aquela irreparada. Configura-se, nesses termos, uma variante mais criteriosa do critério compensatório, em que a mera potencialidade do ressarcimento não basta para tornar presentes os elementos caracterizadores dessa eficiência - é indispensável que a compensação se efetive.

Nesta perspectiva, a necessária compensação não se trata, no entanto, de mera compensação ampla, em que o aumento da riqueza social justifica as perdas de alguns de seus membros, mas, sim, refere-se à reparação efetiva daqueles negativamente afetados - levada a cabo com os recursos extras decorrentes do ganho de eficiência ampla.

Essa compensação, efetiva, poderia ser promovida pelas próprias relações de mercado caso os custos de transação fossem insignificantes. Isso porque aquele que

104 HIERRO, Liborio. Justicia, igualdad y eficiencia. Madrid: Centro de Estudios Políticos y Constitucionales, 2002. p. 23. 
aproveitou ganhos vultosos estaria disposto a indenizar aqueles que padeceram na modificação uma queda , minoração, em seu nível de riqueza - utilidade ou bem-estar.

Dada a relevância dos custos de transação, na maior parcela das circunstâncias, as relações privadas não são capazes, por si mesmas, de praticar a efetiva compensação entre aqueles que perceberam grandes ganhos e aqueles que sofreram prejuízos.

Cabe então ao Direito a função de estabelecer que - ainda que permitidos os atos que causem danos em benefício de ganhos maiores - esses danos devem ser adequadamente indenizados. Enfatiza-se que o papel das instituições jurídicas não é o de obstar as transações que causem danos, mas até mesmo promovê-las quando significarem maximização da riqueza agregada, mas deve observar rigorosamente sua função social de fazer que a compensação de danos seja levada a cabo, a fim de não desenvolver incentivos a qualquer descumprimento obrigacional ou estimular a ocorrência de qualquer lesão.

Em face desse critério compensatório mais exigente, conforma-se, na realidade, uma maneira pela qual a eficiência paretiana é alcançada, pois, se parte dos agentes afetados obtiverem ganhos e os demais forem compensados pelas perdas que tenham sofrido, logo, tornam-se presentes as condições de maior exigibilidade para a configuração da eficiência de Pareto, pois todas as partes afetadas ficaram na mesma ou em melhor situação - ainda que tal tenha se dado somente mediante a atuação institucional.

A bem da verdade, no entanto, é impossível que se compensem todos os que tenham percebido prejuízos com dada transação ou implementação de políticas através do Direito, já que não é simples determinar quem são os envolvidos indiretos e tampouco quão grandes serão os danos sofridos futuros em razão de uma intervenção qualquer.

Outra crítica comum ao critério compensatório é o denominado paradoxo da reversibilidade. A utilização deste critério de eficiência como parâmetro para a decisão pode levá-la ao bloqueio em face de circunstâncias, possíveis, em que a transição de uma situação alocativa A para uma situação B é desejável, mas, dada a instituição da situação $\mathrm{B}$, sua reversão para a situação $\mathrm{A}$ também atende o critério 
compensatório. ${ }^{105} \mathrm{O}$ problema não se resolve simplesmente com o uso dos elementos do argumento em análise e necessita sua ampliação, de maneira a dar à esco

lha um caráter político - e não meramente racional, economicista, relativamente neutro.

Ainda no que se refere às evoluções enfrentadas pelos critérios compensatórios para avaliação da eficiência, vale apresentar ainda as interessantes inovações trazidas por Richard Zerbe Junior. Esse autor parte do já apresentado critério Kaldor-Hicks de compensação potencial e estabelece outros seis fatores a informar o operador que busca um critério mais amplo e cioso de suas limitações ${ }^{106}$.

Desse modo, além de proceder a uma busca pelas situações que maximizem o agregado, deve-se ainda, prescreve Zerbe Jr., manter em mente que a avaliação que resulte dessa análise deve servir como informação adicional àquele que toma a decisão e não determinar em termos absolutos o que é correto fazer. É importante ainda reconhecer que as perdas e ganhos são inerentemente subjetivas e, portanto, de natureza psicológica, inexpressável em termos econômicos com perfeição.

Quanto ao nível de informação disponível para a análise, Zerbe alerta que (i) uma decisão eficiente não deve demandar informações que não estão disponíveis, (ii) decisões tomadas mediante o uso de melhor informação são preferíveis frente àquelas que foram feitas com informação corrompida ou em menor quantidade, e (iii) como o nível de utilidade dos indivíduos não pode ser medido objetivamente, trata-se de uma informação não disponível e, portanto, decisões devem prescindir da análise de tal elemento.

No que se refere à implantação das medidas eleitas, é preciso atentar para o fato de que, revela o autor, há custos relacionados à qualquer mudança institucional. Dessa maneira, o analista deve levar em conta os custos de transação provenientes da medida, além dos custos relacionados com a implantação de novas regras e custos dos sistemas administrativos que se encarregarão de efetivar a compensação àqueles que se viram prejudicados pela alteração Kaldor-Hicks eficiente.

Os valores pertinentes à análise, pontua Zerbe, são aqueles pelos quais há algum desejo de se pagar. Outros valores, que usualmente se ocultam devem ser lembrados. Inclui-se aqui os custos já mencionados e os valores que se está disposto a

\footnotetext{
${ }^{105}$ ZERBE JR., Economic efficiency in Law and Economics, p. 8.

106 ZERBE JR., Economic efficiency in Law and Economics, p. 17.
} 
pagar em benefício dos outros - o altruísmo tem seu preço e esse custo deve ser incluído na avaliação.

Por fim, o autor ainda alerta que a alocação vigente de direitos e conceitos morais é fundamental para a análise de eficiência, já que afeta a maneira pelas quais os indivíduos valoram as coisas e as decisões.

Ainda que muito se possa avançar no debate quanto ao critério compensatório de caracterização alocativa da eficiência, haveria ainda que se atentar para a idéia de eficiência na distribuição de riqueza ou utilidades.

\subsection{Eficiência distributiva}

Para os principais teóricos da Análise Econômica do Direito, é muito difícil avaliar a eficiência distributiva com critérios econômicos seguros e objetivos, pois, de acordo com os modelos descritos, a distribuição fica, a princípio, a cargo do próprio mercado. Isso impossibilita que a justiça de mercado seja avaliada por critérios de justiça distributiva que não sejam vinculados a esse mesmo mercado. Em outros termos, é difícil traçar um referencial econômico ideal de distribuição dentro do mercado que não seja aquele que o próprio mercado institui ${ }^{107}$.

$\mathrm{Na}$ lógica do mercado, entre os determinantes dessa distribuição podem ser apontados a sorte e vantagens em função do caráter, da aptidão ou da inteligência.

De um lado extremo, os mais deterministas acreditam apenas na sorte como fator atrativo de bens, crendo que merecimento não é relevante; ainda que tenham certa razão em suas afirmações, é válido prestar devida atenção ao fato de que quanto mais crédito se dá à sorte, menos se crê na possibilidade de interferir na distribuição de riqueza - mesmo através da técnica.

De outro extremo, há a crença de que a aptidão natural ou desenvolvida é o mais importante elemento nessa equação distributiva. Assim sendo, um sistema de mercado tenderia somente a majorar as diferenças naturais entre os indivíduos, super beneficiando os mais aptos em detrimento dos demais. Em verdade, é preciso também

${ }^{107}$ POSNER, Economic Analysis of Law. 
relativizar essa concepção, pois, em razão das circunstâncias, muitas vezes não há possibilidade de fazer valer a perícia que se detém.

Segundo uma abordagem conservadora, as ciências econômicas podem revelar pouco ao Direito sobre as qualidades de um sistema distributivo, sendo apenas capaz de descrevê-lo e demonstrar as possíveis conseqüências resultantes de qualquer interferência $^{108}$.

De acordo com mesma perspectiva positivista da Escola Neoclássica, a Economia pode predizer as conseqüências da norma quanto ao atendimento de quaisquer critérios de eficiência alocativa e produtiva de maneira estritamente técnica, mas não poderia, segundo alegam alguns de seus autores mais positivistas, fazer uso de critérios morais para prescrever meios para a mudança social no que se refira à distribuição da riqueza ou utilidades. Essa é, paralelamente, a concepção adotada pela corrente descritiva da Análise Econômica do Direito ${ }^{109}$.

Assim, qualquer distribuição diversa daquela operada pelo mercado decorre de uma decisão política, a princípio não fundamentada tecnicamente em instrumentos econômicos. No entanto, a teoria econômica poderia demonstrar ao menos quais são os incentivos que uma escolhida política de distribuição cria na realidade socioeconômica, além de demonstrar quais são os custos envolvidos nessa redistribuição ${ }^{110}$.

Por exemplo, criará incentivos para o aumento da oferta de um determinado mercado caso permita que os ofertantes do setor internalizem algo além do que o preço ideal - custo marginal. Poderá, de outro lado, aumentar o consumo caso seja feita a opção pela apropriação pelos demandantes de qualquer utilidade.

Uma vez efetuada uma opção social por promover distribuição distinta daquela de mercado, a Economia pode eventualmente ser útil para esclarecer que meios são mais adequados para que se atinja o fim cominado, mantendo coerência racional entre os meios empregados e a finalidade, mas, mesmo em tais circunstâncias, pouco pode afirmar a respeito da justiça da opção. Em sua análise normativista, somente, poderá avaliar se é economicamente producente ou não.

\footnotetext{
108 “A Economia não responde se a distribuição de riqueza ou renda existente é boa ou ruim, justa ou injusta. No entanto, pode nos dizer muito sobre os custos envolvidos em sua alteração, bem como sobre as conseqüências distributivas de acordo com a adoção de uma eficiência alocativa de recursos que seria ética ou socialmente desejável.” POSNER, Economic Analysis of Law, p. 14.

109 Diferenças entre a perspectiva positivista e a normativista são tratados no Capítulo 2.

110 POSNER, Idem, p. 470.
} 
No entanto, apesar dessa postura conservadora de alguns autores a respeito da incapacidade das Ciências Econômicas avaliarem a justiça de uma dada opção distributiva ou alocativa, é possível encontrar aqueles que fazem uso dos modelos econômicos para desenvolver um critério moral economicista a julgar, sim, tais decisões. Esse critério parece ter seu fundamento último no consenso e ter como foco a promoção da eficiência. ${ }^{111}$

${ }^{111}$ Mais ampla abordagem sobre como a Teoria Econômica do Direito pode ser sensível a anseios sociais por redistribuição de recursos será apresenta no Capítulo 4 do presente estudo. 


\section{EFICIÊNCIA ECONÔMICA NA FORMAÇÃO DO DIREITO}

Como argumentado nos capítulos anteriores, há pouca controvérsia dentre os autores da Teoria Econômica do Direito a respeito da conveniência da promoção sempre maior da eficiência das estruturas sociais e relações interindividuais. Isso afeta em larga escala a formação e aplicação do Direito.

Da eleição da eficiência como um valor a guiar as decisões sociais decorre a necessidade de que, ao instituir suas regras sociais, qualquer sociedade se ocupe detidamente dessa substância normativa, de maneira a promover desenho economicamente adequado de suas normas. Essa importância torna-se ainda maior em situações reais, em que os custos de transação são positivos e o conteúdo daquilo que vem a se impor como Direito torna-se ainda mais relevante, já que a alocação de direitos passa a fazer diferença sob a perspectiva da eficiência, uma vez que intefere na alocação final de recursos. Eis a justificativa que propõe os textos em estudo para que se alce o debate economicista sobre o Direito a um patamar prioritário.

No entanto, é notório que o Direito nem sempre se constitui de maneira economicamente esclarecida. Portanto, legislação e decisões judiciais, insensíveis às suas conseqüências, acabam por gerar perversos incentivos, contrários a qualquer critério de eficiência. Coloca-se um problema: sendo possível que o Direito apresente maior eficiência do que a averiguada na realidade, o questionamento sobre as causas dessa distorção se torna fundamental.

Em face desses pressupostos e constatações, torna-se importante o estudo dos modos de produção e aplicação do Direito a fim de revelar que tendências estão vinculadas às atuais estruturas nomogênicas e investigar a que interesses e axiomas o atual modelo de produção do Direito é sensível ou não.

Para tanto, busca-se efetuar uma análise positiva do modelo de escolha pública adotado em democracias representativas como a brasileira, especificamente acerca daquelas escolhas que resultam em normas e são efetuadas pelo Legislativo.

Nesse tema, investiga-se como a oferta de normas gerais e abstratas se dá em um ambiente em que a demanda por tutela jurídica fica dependente do poder de monopólio estatal e refém dos agentes políticos que controlam esse poder. Menos do que 
investigar que forças efetivamente têm influenciado o legislador brasileiro, o que se buscará é analisar a que tipo de interesses o modelo se mantém exposto.

A seguir, o foco recai sobre o papel sócio-econômico atribuído pela Teoria Econômica do Direito à interpretação das regras jurídicas instituídas. Nesse tópico, ganha relevância a atuação do Judiciário, que carrega um papel central no estabelecimento de interpretações vinculantes e, portanto, apresenta desempenho a ser avaliado de uma perspectiva socioeconômica.

Lembramos que o Poder Judiciário pode ser considerado a instituição derradeira na sinalização formal das condutas que são efetivamente sancionadas e na definição daquelas outras que o sistema jurídico tolera ou promove. Reconhecer os ditames que devem informar a interpretação das normas e descrever os limites que condicionam a decisão judicial é fundamental para que se possa traçar uma comparação entre o prescrito e o que de fato se efetiva e, verificada sua adequação ou desajuste, seja possível traçar os primeiros apontamentos deliberadamente em viés normativo acerca de possíveis melhorias a serem instituídas no paradigma de gestão da coerção estatal ${ }^{112}$.

\subsection{Intervenção ótima do Direito}

Por trás da concepção que destina ao Direito a capacidade de gerir relações interindividuais está a idéia de que, ao lado de outras regras sociais, as normas jurídicas desempenham influência sobre a conduta dos agentes mediante a criação de incentivos a práticas socialmente desejáveis e a obstrução daquelas cujos resultados não são producentes.

Contudo, não é tarefa trivial definir o nível ótimo de intervenção que o Direito deve instituir mediante suas normas. Mesmo intervenções economicamente bem intencionadas, pró-eficiência, podem vir a trazer custos elevados relacionados à manutenção do aparato institucional e coercitivo que acabam por tornar sua implantação algo irrazoável. Aliás, a partir de certos níveis de intervenção é comum que se verifique

112 Refere-se aqui especialmente ao modelo jurídico romano-germânico, mas é possível estender a qualquer Direito que se qualifique como moderno na medida em que essa modernidade se caracterize pela constituição de técnicas que excluem do Direito relações que são defendidas como estranhas ao ordenamento, afastando o sistema jurídico da moral e também da Economia. 
uma certa indiferença social ao ditame jurídico e se torna inútil qualquer intento no sentido de aumentar seu enforcement, o que significaria apenas investimento sem resultados práticos.

É preciso lembrar que, em circunstâncias ideais, a alocação de Direitos é irrelevante e os bens e vantagens migrarão daqueles que os valorizam menos para aqueles que os tem em maior conta, mediante transações. ${ }^{113}$ No entanto, em face da existência de custos de transação, é preciso que o Direito estabeleça a alocação de prerrogativas - vale dizer, direitos - em benefício daquelas partes que, via de regra, são as que lhe dão maior valor, ou então o faça de maneira que as exigências jurídicas responsabilidades - recaiam sobre aqueles que, através da conformação de suas condutas, possam evitar perdas e danos ao menor custo possível.

Além disso, é preciso notar que quando há um adequado nível de enforcement o Direito será efetivado a menores custos. Quando o conteúdo da norma reflete bem a alocação ótima de bens e prerrogativas, o interesse privado de eventuais lesados é suficiente para que, através do uso do mínimo aparato público ou até mesmo privado de enforcement, a decisão político-jurídica seja efetivamente implementada.O dispositivo da norma passa a ser estrategicamente utilizado como instrumento para a negociação entre indivíduos e seu conteúdo configura-se como a referência a partir da qual as partes podem negociar e efetivar transações que satisfaçam as expectativas de ambas, sem que o aparato público de execução da norma seja realmente acionado.

Como exceção a essa regra geral em que os incentivos para que os indivíduos assumam a defesa de seus interesses tendo a norma apenas como referência, existem os denominados "bens públicos"" situação em que não há incentivos suficientes para que um particular venha a se insurgir isoladamente na defesa do bem atacado, geralmente de interesse social. Em tais casos, a atitude pró-ativa do ente estatal é fundamental para que as normas sejam cumpridas, condutas sociais influenciadas e algumas delas reprimidas.

\footnotetext{
${ }^{113}$ Importante salientar que nem todos os teóricos vinculados à Análise Econômica do Direito fazem uso uniforme dos postulados da denominada Economia dos Custos de Transação. Autores como Richard Posner preferem fazer uso do instrumental tradicional da teoria microeconômica e usam conceitos como "assimetria de informação" e "distribuição de riscos" para tratar do mesmo problema, ainda que de maneira diferenciada.

114 Bens públicos, revela a teoria econômica, são aqueles não rivais e não excludentes, apropriáveis inclusive por aqueles que não contribuíram para sua prestação. Quando reconhecida a existência, no caso em análise, de um bem público, caracterizam-se os incentivos para o free-rider, aquele que goza das utilidades de um recurso sem custear seu desenvolvimento, manutenção ou distribuição.
} 
Contudo, mesmo em tais casos é preciso salientar a existência de custos relacionados (a) à instituição de regras,jurídicas (b) desenvolvimento e manutenção do aparato público de coleta de informações e julgamento e (c) sustentação de um mecanismo público promotor de sanções. Investimentos nessa estrutura - e conseqüente elevação da intervenção do Direito na sociedade - podem significar aumento de eficácia normativa, mas há limites a partir dos quais novas inversões são inúteis ou indesejáveis.

A possibilidade de que existam investimentos não profícuos decorre da diminuição marginal dos resultados efetivos de gastos em enforcement: a cada montante de recursos (pecúnia, equipamento ou pessoal) empregado na aplicação e cumprimento das regras jurídicas - e políticas subjacentes - diminuem os efeitos que essa destinação causa em termos de concretização de objetivos.

Assim, é preciso fazer uma escolha de qual o nível tolerável de infrações, opção essa que deve ser posta como um trade-off entre maior busca por efetividade normativa e o emprego dessa verba em outras escolhas políticas. É preciso tomar ciência, antes de efetuar uma decisão minimamente racional, que outras satisfações deverão ser sacrificadas a fim de que se invista mais no enforcement de determinada norma ou política pública, sem que o resultado esperado seja atingido em sua integralidade.

Pode-se dizer, assim, que se trataria de uma escolha meramente política a respeito do ponto ideal aos indivíduos considerados (uma dada sociedade), mas mesmo essa pode se deixar avaliar pelo critério da eficiência, já que essa opção política pode traduzir-se em uma expressão coletiva - plurindividual - de preferências, ou seja, de busca por satisfação. Ademais, é possível que essa eleição de prioridades possa ser feita de maneira economicamente esclarecida, já que é possível optar pelo grau de investimento que maximiza a inibição de infrações globais às regras jurídicas em uma análise de custo-benefício.

É importante lembrar, no entanto, que a configuração de uma rede social de incentivos a balizar as condutas individuais não se esgota com a instituição e manutenção de regras jurídicas. Ao lado dessas normas formalmente providas pelas instituições públicas, outras regras sociais estabelecem estímulos a certos comportamentos e impõem penalidades a certa classe de atitudes. Entre essas regras sociais podem ser mencionadas as meramente técnicas e aquelas decorrentes de vínculos 
associativos, mas, entre todas, destacam-se as regras pragmaticaamente denominadas como morais.

Como já referido neste estudo, é muito comum aos autores vinculados à Law and Economics não se deterem na análise das possíveis distinções marcantes entre o Direito e a Moral. Ao invés disso, reconhecem que uma diferenciação pode ser constatada na realidade social e, a partir disso, tratam da complementaridade entre as funções dessas duas modalidades de regras sociais. Desse modo, para verificar o grau ótimo de intervenção dos instrumentos de condução das ações individuais, o estudo sobre a efetividade e a relação custo-benefício proporcionado por regras morais é importante.

Nesse sentido, Shavel1 ${ }^{115}$ avalia a conveniência de delegar, alternativamente, ao Direito ou à Moral a capacidade de regrar as condutas individuais segundo critérios como os custos envolvidos na adoção das regras, o grau de efetividade dessas regras como reguladoras das condutas ao estabelecer incentivos às ações individuais e pela probabilidade de que, caso haja o descumprimento do preceito, promova-se de fato a sanção moral ou jurídica.

Sobre o Direito, referido autor afirma que o custo de instituição de novas regras jurídicas é relativamente baixo para uma dada sociedade, já que basta seguir os procedimentos previstos e, a seguir, promover a sua publicidade, o que tampouco compromete elevado montante de recursos. Mesmo quando elementos complicadores do processo legislativo são trazido à baila pela Teoria da Escolha Pública, afirmando a elevação dos custos relacionados à produção de normas gerais e abstratas, a instituição de regras jurídicas pode ser intentada segundo procedimentos e análises relativamente previsíveis e há maior grau de segurança quanto ao retorno efetivo de inversões efetuadas nessa empreitada.

A manutenção do aparato público de coleta de informações pertinentes, julgamento e promotor da sanção jurídica, por sua vez, demanda maior e mais perene grau de inversão. Essa sanção, aliás, costuma ser de maior gravidade quando comparada a outras modalidades de penas sociais, mas seu nível de coerção pode se ver reduzido pela variável referente à probabilidade de que essa penalidade venha - ou não - a ser

${ }^{115}$ SHAVELL, aw versus Morality as regulators of conduct. American Law and Economics Review, vol. 4, no. 2, p. 227-257, 2002. 
efetivamente aplicada em caso de superveniência de conduta diversa daquela promovida anteriormente.

De outro lado, a instituição de novas regras morais seria mais elevada, já que poderia ser necessária a alteração na matriz cultural de uma determinada sociedade a fim de que se fizesse incluir um novo dispositivo a regrar as condutas individuais. Além de não existir a previsão clara de um procedimento para tanto, todos os esforços nesse sentido podem se frustrar, já que há menos previsibilidade quanto ao sucesso e incorporação da nova regra moral no conjunto de crenças sociais, especialmente porque, diferentemente das regras jurídicas, o seu conteúdo não pode ser exatamente planejado e pode vir a apresentar maiores distorções.

No entanto, disposições morais não carecem de um aparato público e estável que promova seu cumprimento, já que suas instâncias de julgamento e sanção se encontram dispersas entre os componentes de uma sociedade. Além disso, regras morais podem contar com a consciência de cada indivíduo, que pode ver sua auto-imagem negativamente afetada ao transgredir uma regra moral. Dessa maneira, a sanção moral pode ser levemente mais gravosa quando a punição é aplicada por outros indivíduos ou então ser meramente subjetiva, variando bastante em grau, mas de aplicação certa, quando deflagrada internamente pelo próprio indivíduo que a ofende.

É importante esclarecer que essa análise que leva em conta a autoimagem do indivíduo como parte do aparato de enforcement de uma dada regra social pode não se dissociar metodológica e conceitualmente de uma abordagem economicista: ainda que o interesse individual seja o guia das decisões efetuadas, sempre em prol da satisfação pessoal, é possível reconhecer que muitos indivíduos estão dispostos a ceder utilidades "imorais" que gozariam em benefício de uma outra utilidade, qual seja o reconhecimento público de sua boa conduta e a valorização que experimenta em seu conceito sobre si mesmo. Em outros termos, um indivíduo pode estar disposto a pagar ou deixar de auferir - certo valor para seguir como alguém que tem boa reputação e não se vê em conflitos psicológicos por conta de condutas que ofendam os padrões socialmente estabelecidos.

De qualquer modo, os incentivos instituídos pelo Direito, salvo quando verificada uma probabilidade extremamente reduzida de que se efetive a sanção jurídica, seriam mais relevantes quando da tomada da decisão individual, dado seu elevado nível de coerção. As regras morais, no entanto, seriam ideais nas situações em que a 
descoberta da má conduta é impossível ou quando só pode ser revelada quando promovida difusa e informalmente, apelando-se, respectivamente, à capacidade penalizadora da consciência subjetiva e aos esforços sociais por coibir condutas indesejáveis, ainda que em ambos casos a sanção moral seja substancialmente mais branda.

\subsection{Função legislativa e a eficiência do Direito}

Já se afirmou a existência de um custo relacionado à instituição de novas regras jurídicas e da manutenção do aparato público competente para desenvolvê-las e aplicá-las. O passo seguinte é o de reconhecer como essas estruturas de decisões coletivas operam e quão eficientes podem ser o fruto de suas deliberações.

O modelo das democracias representativas modernas atribui a criação da norma jurídica a instituições de caráter representativo, que recebem a função de defender e promover os interesses de seus representados.

No entanto, ainda que formalmente a promoção do interesse coletivo seja confiada aos representantes populares, a maneira pela qual se estruturam as relações de poder e representatividade tende a criar distorções bastante significativas. Mediante o uso dos mesmos pressupostos e modelos econômicos já apresentados, sobretudo a presunção de que cada indivíduo age socialmente de maneira a maximizar sua utilidade, tem-se a constatação de que a disparidade de interesses entre representantes e representados tende a ser freqüente ${ }^{116}$.

Isso decorre do fato de que o representante político é pessoa que atua em nome de seus eleitores, mas possui capacidade para, na execução de seu mandato, buscar a satisfação de seu interesse próprio e não o do aglomerado de representados, conjunto principal que lhe delegou poderes ${ }^{117}$.

Em sua atuação pública, sobressalta-se o interesse do agente político em perpetuar sua presença junto ao poder, o que lhe gera duas classes de necessidades,

\footnotetext{
${ }^{116}$ Para maior detalhamento das premissas da Teoria da Escolha Pública, vide DUNLEAVY, Patrick. Democracy, bureaucracy and Public Choice: economic explanations in political science. London: Harverster Wheatsheaf, 1991. p. 3.

117 BUCHANAN, James. TULLOCK, Gordon. Il calcolo del consenso: fontamenti logici della democrazia costituzionale. Bologna: Il Mulino,1998., p. 80 e seguintes.
} 
ambas intimamente ligadas ao processo de eleição de representantes - melhor dizendo, de sua reeleição como representante para um próximo mandato.

A primeira necessidade a impor mote a seus atos é a de conseguir satisfazer as expectativas mínimas de seus eleitores de maneira a que, em próximos pleitos, ele consiga novamente reunir votos suficientes para se manter no cargo. É importante esclarecer que, no limite, basta que se promova a aparência de que o representante persegue minimamente o interesse de seus representados. O que de fato ocorre nos bastidores das votações parlamentares - e não vem a público - tem pouca relevância.

A segunda necessidade que afeta as ações do agente político é a de oferecer privilégios a pequenos grupos de modo a que, com a extração de recursos destes, consiga financiar suas campanhas eleitorais e talvez até mesmo incrementar sua renda, o que certamente configura uma conduta pouco reta, mas previsível uma vez que se assuma a capacidade preditiva da instrumentalização do tipo individual conforme descrito pela sociologia econômica ${ }^{118}$.

Assim, é preciso que o representante faça chegar aos sentidos de seus representados a informação de que vela por seus interesses - não menos individuais, ainda que coletiva ou difusamente apresentados - e, paralelamente, prestigiar o interesse de grupos minoritários a fim de garantir o recebimento de recursos dos investidores de campanha. Essas duas ordens de demandas - majoritárias e minoritárias - raramente coincidem em substância, já que a manutenção de privilégios rentáveis para alguns costuma significar a atribuição de custos supérfluos aos demais.

No que se refere à premência de contentar seus eleitores, é importante ressaltar que a cobrança por parte dos representados depende muito dos custos relacionados à demanda política ativa: informar-se das matérias em votação no Legislativo e fazer sua opinião chegar ao congressista pode significar alto investimento de recursos escassos.

Esses investimentos tenderão a ser feitos quando os benefícios que se pode esperar da tutela forem superiores aos custos envolvidos e quando esse retorno se der somente para uma isolada classe de indivíduos. Quanto maior a abrangência dos beneficiários em potencial, mais difusa é a vantagem futura possível e maiores são os incentivos para que qualquer dos indivíduos deixe de cooperar no pleito pela tutela.

118 POSNER, Economic Analysis of Law, p. 535. 
Em outros termos, constata-se que a promoção do interesse majoritário exige a movimentação de número muito maior de representados para compor um organismo com legitimidade e poder suficiente para lograr pressão efetiva junto aos agentes políticos.

Isso decorre do reconhecimento de que os benefícios seriam muito mais difusos e pouco importariam em maximização da satisfação individual e, de maneira mais acentuada, deriva da consciência de que todos serão beneficiados em caso de sucesso do grupo de defesa majoritário - todos inclusive aqueles que não contribuíram com o movimento.

Essa é a circunstância ideal para o "carona"119 (free rider), indivíduo que percebe que, no movimento por tutela estatal de seus interesses, só é vantajoso investir em pressão junto ao agente político se (i) o benefício almejado for bastante singular, se (ii) ele for um dos poucos privilegiados e, também, se (iii) sua participação agregar efetiva força ao movimento. Nenhum desses três elementos são comuns nos movimentos em defesa de interesses sociais amplos são desenvolvidos ${ }^{120}$.

Em razão desses fatores, os grupos de promoção de interesses de pequenas parcelas sociais - minorias - tendem a fazer pressão mais efetiva, pois há maior incentivo à adesão, já que os ganhos obtidos serão contabilizados somente pelo pequeno bloco e, com um número pequeno de adeptos, já se perfaz uma grande representação da camada postulante. Além disso, os custos, que difusamente serão atribuídos às maiorias, reverterão recursos a serem divididos entre poucos, o que majora o valor esperável ${ }^{121}$.

Apesar dessas distorções referentes aos incentivos existentes para cooperar com movimentos de expressão de interesses, ainda é relevante a imagem que os eleitores, grupos majoritários, tem da conduta de seus representantes. Assim, ainda que de fato se descrevam imperfeições no fluxo de informações entre representantes e representados, seria possível afirmar que há uma espécie de mercado eleitoral em que políticos vendem tutela jurídico-estatal aos eleitores, que o remuneram através de seus votos. Esse mercado seria capaz de contrabalançar, quando de sua melhor performance,

${ }^{119}$ Esse fenômeno ocorre porque "aquele que está dentro do escopo protetivo de uma proposta de lei será beneficiado tendo contribuído ou não para sua promulgação". POSNER, Economic Analysis of Law, p. 534.

120 OLSON, Mancur. La logica dell'azione collettiva: i beni pubblici e la teoria dei gruppi. Milão: Feltrinelli, 1983. p. 35.

121 BARZEL, Yoram. A theory of the State: economic rights, legal rights and the scope of the State. Cambridge: Cambridge University Press, 2002. p. 115. 
de maneira relativamente adequada as demandas dos representados e a ação dos congressistas $^{122}$.

Contudo, trata-se de um mercado em que os custos de transação costumam ser elevados. Além dos custos de adquirir informação, acompanhar a atividade parlamentar, influenciar nas opções do representante, existem custos outros que podem ser constituídos mediante a atuação dos pequenos grupos de interesse e que se cristalizam nas instituições ${ }^{123}$.

Pequenos grupos de interesse, na busca por tutela privilegiada, podem fazer uso de mecanismos legislativos que inibem a contestação pelas maiorias. Uma técnica que exemplifica muito bem esse tipo de estratégia é a difusão máxima da arrecadação dos recursos que subsidiarão o benefício ao pequeno grupo - quanto menor for o valor de contribuição individual dos prejudicados, menores serão os incentivos para que o amplo grupo onerado insurja-se contra o projeto de lei, por exemplo.

Isso decorre da constatação, pelo indivíduo lesado, de que os custos decorrentes da contestação são mais elevados que os custos que ele, isoladamente, virá a ter em face da aprovação da norma. Contudo, ainda que para cada indivíduo negativamente afetado não seja proveitosa a contestação, no agregado social passa a haver a transferência de renda não desejável, já que normas dessa modalidade não instituem nem mesmo transições de soma zero, mas sim implantam perdas de pesomorto, relacionadas aos custos de coleta e transferência desses recursos ${ }^{124}$.

Ademais, podem ser desenvolvidas barreiras institucionais substanciais à revisão das decisões políticas que produzem normas. A sinalização de que o processo de pleiteio é caro - em termos de recursos materiais e tempo - e seu sucesso é imprevisível em face da reiterada demonstração de captura dos legisladores acaba por se assentar a percepção generalizada de que investir em tutela legal é arriscado e somente se faz racional para pequenos grupos que conseguem grandes privilégios e, de outro lado, pouco proveitosa para aqueles indivíduos que querem se ver livres de pequenas contribuições.

122 BUCHANAN, James. Politics without romance: a sketch of positive Public Choice Theory and its normative implications. In: BUCHANAN, J. et al (eds.). The Theory of Public Choice - II. Ann Arbor: The Michigan University Press, 1984. p. 14.

${ }^{123}$ CREW, Michael A. TWICHT, Charlotte. On the efficiency of law: a public choice perspective. In: KLUWER ACADEMIC PUBLISHERS. Public Choice. vol. 66, n. 1, 1990. Netherlands. p. 21.

${ }^{124}$ Neste caso, o peso morto é constituído por todos os custos evitáveis e, portanto, inúteis e ineficientes. BARZEL, A theory of the State, p. 125-129. 
Nesse sentido, sempre que pequenos grupos de interesse vencem um pleito, confirma-se a crença de que é pouco provável que a ação de grandes grupos seja bem sucedida. Essa informação dissemina-se e torna-se cada vez menos provável que se consiga angariar recursos e engajamento massivo na defesa de interesses majoritários. A concepção que os entes legiferantes servem especialmente a interesses minoritários mediante a instituição de privilégios incorpora-se à cultura política e social, reforçando o desincentivo à defesa de interesses da maioria.

Em suma, muito diferente de um perfeito mercado por normas ou tutela estal, a relação entre representantes e representados na produção de regras jurídicas gerais e abstratas se dá de maneira bastante conturbada, distorcida e desequilibrada, em razão do conjunto de incentivos e óbices próprios ao modelo vigente.

Em face dessa realidade, torna-se possível mais um exercício de aplicação do Teorema de Coase às relações sociais, agora às demandas por tutela legal. Se os custos de negociação para que as partes atingidas pela norma - benéfica ou negativamente - fossem nulos, as más externalidades geradas pela ação dos pequenos grupos de interesse seriam barganhadas com os beneficiários e se tornariam compensáveis $^{125}$.

Nesse hipotético cenário de baixos custos transacionais, somente haveria incentivos para a ação de pequenos agrupamentos quando a instituição da norma privilégio - gerasse maiores ganhos a estes poucos elementos que prejuízos aos grandes grupos sociais. Em outras palavras, somente seriam promulgadas regras jurídicas que fossem eficientes de maneira agregada, já que em tais casos as transações posteriores seriam suficientes para que ninguém fosse movido a uma situação pior - todos seriam compensados pelas eventuais perdas. A maximização da utilidade, riqueza ou bem-estar se assegurariam pela própria atividade dos indivíduos.

Por fim, cabe demonstrar qual a relevância do meio institucional para movimentos de reforma da estrutura normativa. Tendo como substrato essa realidade apresentada de ação de grupos de defesa de interesses minoritários ou majoritários, é comum que a autoridade se veja em face da necessidade de efetuar alterações substanciais no enquadramento jurídico da sociedade.

Reformas do Estado e do aparato que dá base às relações privadas ou à propriedade, bem como soluções redistributivas assistenciais, podem ser intentadas sem

125 MICELI, Economics and the Law, p. 9. 
que se reconheça que propostas, ainda quando muito bem formalizadas, podem ter pouca capacidade real de viabilização ${ }^{126}$.

Não é uma tarefa simples explanar aos eleitores que, em razão de bem agregado, perderá um direito que lhe tenha sido anteriormente alocado. Para esses indivíduos, pólo principal do poder político que vem a ser delegado aos agentes públicos, não basta que seja promovida maior eficiência agregada, o que beneficiaria toda a sociedade.

Ainda que um valor solidário possa significar, sim, alguma utilidade para o representado político ou então para o eleitor prejudicado, há forte tendência de que o indivíduo não venha a aceitar quaisquer alterações que venham a lhe deixar em situação pior. Por vezes, tamanho é o rigor na defesa de suas expectativas que indivíduos podem vir a apresentar comportamentos irracionais como a não aceitação da manutenção de sua condição em face de alteração em que outros foram beneficiados, exigindo, também para si, grau de melhoria ${ }^{127}$.

Eis uma das razões pelas quais o cenário de implantação de uma norma é tão importante quanto o desenho de sua substância, já que, para facilitar sua aceitação, pode ser possível alinhar os interesses daqueles que já possuem vantagens e aqueles a quem a regra pretende beneficiar - obviamente, não se trata de uma tarefa simples. Também em função disso, o transplante legal de um cenário institucional a outro pode não atingir as finalidades almejadas: há sempre interesses locais, de um lado, engajados individualmente na manutenção e melhoria de seus privilégios e, de outro lado, massas desestimuladas a promover as mudanças que se mostrem imprescindíveis para o desenvolvimento agregado.

Todas essas características compõem a realidade contextual sobre as quais reformas jurídicas e melhorias institucionais são intentadas. Portanto, é fundamental que, além de um desenho economicamente adequado da norma, é preciso que seu projeto leve em consideração o ambiente institucional no qual deverá ser aprovado e aplicado, sob pena de que não venha a lograr sequer sua aprovação legislativa ou, caso venha a conseguir, careça de qualquer efetividade quando de sua vigência.

126 BUSCAGLIA, Law and Economics in developing countries, p. 18.

127 Estudos empíricos demonstram que, em jogos simulados, um jogador freqüentemente prefere nada receber ao invés de receber pouco e permitir que o outro jogador receba muito. CHORVAT, Terrence et al. Law and Neuroeconomics. GEORGE MASON UNIVERSITY SCHOOL OF LAW. Law and Economics Working Paper Series. Disponível em: http://ssrn.com/abstract=501063. p.19 e seguintes. 
É ainda preciso fazer uma observação quanto aos países em que vigora o sistema romano-germânico, o Civil Law. Uma vez que essa tradição jurídica aponta o Direito como aquele positivado, especialmente instituído pelo Legislador através de atos que lhe são próprios, validados através das regras de reconhecimento já presentes no sistema, o papel que a eficiência pode ter como guia moral pode depender de sua positivação em norma jurídica. Isso, sem dúvida, facilitaria a defesa de sua aplicabilidade nas mais diversas questões que se apresentam em face do Direito.

No entanto, não é apenas quando da formulação de normas gerais e abstratas que a eficiência pode ser adotada como um critério avaliador da adequação econômico-social da interferência do Direito no resultado agregado. Também na interpretação e aplicação dessas normas, a eficiência pode ser implementada, a fim de que se promova a maximização - da utilidade, riqueza ou bem-estar - através de decisões de caráter jurídico.

\subsection{Eficiência na interpretação do Direito}

Delineada a primeira instância de produção formal do Direito, convém passar à análise da interpretação e da aplicação das regras jurídicas instituídas pelos setores competentes. Nesse tema, é da maior relevância a investigação especialmente sobre como atuam os centros formais de interpretação do Direito, motivo pelo qual o Poder Judiciário passa a ser alvo de análise.

Partindo das afirmações de Richard Posner ${ }^{128}$ de que o Judiciário seria menos suscetível a pressões de grupos de interesse - especialmente em países como o Brasil onde se assegura a estabilidade dos cargos - resta investigar que elementos na estrutura cognitiva e procedimental do Direito levam à configuração de interpretações que nem sempre se deixam influenciar por conhecimentos creditados como não genuinamente jurídicos, como aqueles fornecidos pelas Ciências Econômicas.

\footnotetext{
${ }^{128}$ POSNER, Economic Analysis of Law, p. 532-542.
} 
Quando trata da eficiência promovida pelos tribunais ${ }^{129}$, o mesmo autor declara que a proximidade do juiz em relação ao caso concreto, dentre outros elementos vinculados às preferências judiciais pela promoção da eficiência, seria o bastante para que o Direito constituído por vias processuais pudesse ser mais profícuo economicamente que aquele, geral e abstrato, instituído mediante a atuação dos grupos de interesse junto ao Legislativo. É sobre essa afirmação que estaria ainda assentada sua crença de que os sistemas jurídicos consuetudinários teriam maior capacidade de oferecer a seus jurisdicionados uma resposta jurídica que tratasse dos conflitos com maior proficiência, social e econômica.

De fato, é comum no debate teórico a respeito da evolução do Direito moderno a declaração de que um certo grau de prudencialidade, flexibilidade para readequação judicial da norma geral, é fundamental para que se atinjam objetivos mediante a interpretação e aplicação da regra jurídica no caso concreto. Essa abertura seria especialmente relevante quando da busca pela promoção da eficiência econômica através das estruturas jurídicas atuais, nem sempre confeccionadas de maneira economicamente esclarecida.

Em razão de sua produção jurídica ser especialmente jurisprudencial, o sistema consuetudinário apresentaria maiores vantagens comparativas, já que em primeira análise pode parecer que suas mais relevantes instituições produtoras do Direito - naquele sistema, os tribunais - são mais livres que os magistrados da Civil Law, que teriam papel dito secundário na formação do Direito.

Entretanto, essa aparência é contestável, vez que também naquele modelo de prestação jurisdicional o magistrado encontra limites à sua decisão. Deve buscar como parâmetro as soluções encontradas em julgados precedentes, que - caso se reconheça a similaridade - devem ter suas regras reaplicadas à lide pendente de apreciação.

Ademais, é possível notar que, menos do que a adoção por um ou outro sistema jurídico, é todo o cenário institucional - sócio-econômico e cultural - que prepondera no estabelecimento de circunstâncias em que o desenvolvimento econômico é facilitado. Por tal razão, há estados de tradição consuetudinária que não puderam

\footnotetext{
${ }^{129} \mathrm{O}$ item do presente estudo não trata da eficiência produtiva dos tribunais, no problema de quão rápidos ou poupadores de recursos podem ser os juízes como condutores de procedimentos de julgamento sob normais processuais. O objetivo é compreender como a interpretação e aplicação do Direito podem também ser direcionadas segundo o intuito de estabelecer incentivos sociais que promovam eficiência nas relações interindividuais.
} 
consolidar instituições nem criar os pressupostos mínimos para o desenvolvimento sustentado de suas economias; a mera adoção da Common Law pouco lhes foi favorável.

Ainda que essas considerações tenham grande capacidade explicativa, há elementos outros que podem apontar os motivos pelos quais o Direito constituído judicialmente, seja no sistema consuetudinário ou no romano-germânico, apresenta inadequações econômicas.

A explicação está assentada em larga medida sobre a configuração que tomou o Direito em seu processo de modernização. O Direito moderno se constituiu de maneira a formalizar-se mediante a exclusão de seu interior de ponderações religiosas, morais, econômicas e políticas, que passaram a ser tratadas como elementos extra jurídicos e, ainda quando assumidamente relevantes no caso concreto, não são considerados fundamentos válidos para a decisão judicial ${ }^{130}$.

Pelo fato de não se sensibilizar das conseqüências econômicas de suas decisões, o intérprete falha pela capacidade limitada de cognição da realidade na qual a norma interfere. Isso decorre do fato de que o Direito moderno costuma ser reconhecido como uma instituição estruturada a partir de recursos teóricos auto centrados e encontra sua fundamentação dogmática em sua lógica interna própria. Faz uso de técnicas hermenêuticas para encontrar sua verdade tão somente jurídica e com esta se satisfaz. Amplamente adotada essa concepção mais restrita acerca de suas capacidades, o Direito tornou-se pouco sensível a esclarecimentos que lhe pudessem ser trazidos pelas Ciências Econômicas ou pela análise mais exploratória da conjuntura em que é aplicado.

A insensibilidade do Direito para a Teoria Econômica, no entanto, não o fez menos relevante como um formador do cenário institucional sobre o qual as relações econômicas ocorrem. As transações continuaram a ser efetuadas à margem dessa incapacidade jurídica de lhes fornecer circunstâncias mais estáveis e, portanto, favoráveis. $\mathrm{Na}$ verdade, o contrário parece mais verdadeiro: em sua maioria, decisões judiciais são quase aleatoriamente promotoras ou negadoras da eficiência, sem que se possa traçar um viés consolidado de abordagem jurídica da realidade, de uma perspectiva econômica.

\footnotetext{
${ }^{130}$ É defensável a idéia de que o amadurecimento dos sistemas romano-germânico e consuetudinário tenha se dado em momentos diferentes e disso tenha resultado diferida capacidade de cada um dos modelos de ser influenciado por motes de eficiência. Vide RUBIN, Derecho consuetudinario y derecho estatutário. In: ROEMER, Derecho y Economia, p. 329.
} 
A proposta da Análise Econômica do Direito vem justamente no sentido de reinserir na lógica interna do Direito ponderações de conteúdo teleológico, para que o julgador se cientifique das conseqüências de seus atos e, mais especificamente, dos resultados de sua decisão sobre o bem-estar agregado da sociedade, a fim de que possa, então, promover a sempre maior eficiência das instituições através de decisões economicamente esclarecidas ${ }^{131}$.

É claro que, desafortunadamente, não se trata de uma tarefa simples. Quando essa perspectiva econômica passou a efetuar análises dos conflitos que eram trazidos ao Judiciário, colocou-se um problema adicional: o trade-off que por vezes se constatava entre eficiência no caso concreto e a promoção da eficiência institucional.

Isso ocorre porque o intérprete pode se ver em face de uma situação em que, por exemplo, o resultado agregado primário do inadimplemento contratual, no caso isolado, parece eficiente, mas pode não sê-lo quando considerado globalmente. Esses são aqueles eventos em que as perdas geradas pela quebra contratual são inferiores aos benefícios que qualquer das partes vê no descumprimento obrigacional. Nesses casos, ainda que uma das partes se experimentasse piora em sua situação com o oportunismo da outra, seria compensatório - nos termos já explanados - o não cumprimento das obrigações acordadas.

Para Posner ${ }^{132}$, em tais circunstâncias basta que o Direito, através da intervenção judicial, permita a inadimplência, mas garanta o ressarcimento das perdas sofridas pelas partes frustradas, já que os valores auferidos pelo inadimplente seriam altos o suficiente para indenizar os danos e ainda restar algum valor ao oportunista. Referido autor propõe, assim, que o Judiciário mimetize a alocação final que seria viabilizada em ambiente de custos de transação nulos e promova as compensações de modo a que uma realocação Kaldor-Hicks se transforme em paretiana.

No entanto, é preciso atentar para o fato de que os custos de recorrer ao Judiciário para obter indenizações e referentes à incerteza do sucesso postulatório são significativos e devem ser contabilizados. Ademais, não se pode olvidar que conseqüências emanam de uma decisão como a proposta. Externalidades negativas surgiriam de uma sentença dessa modalidade, mediante a sinalização para os demais

\footnotetext{
131 Importante salientar que não se trata da busca da implantação de um modelo ótimo, ideal e sem imperfeições, mas da busca pela melhoria contínua do ambiente instituído também pelo Direito.

132 POSNER, Economic Analysis of Law, p. 529.
} 
agentes econômicos de que o inadimplemento obrigacional pode vir a ser tolerado pelos meios de coerção estatal.

A perda da confiança no enforcement público dos acordos significaria maiores custos relacionados ou à adoção de meios privados e à antecipação das perdas decorrentes de desarranjos contratuais, custos esses que podem significar a não viabilidade de vasto número de negócios. Em outros termos, os custos de transação aumentam em ambientes em que os meios públicos de coerção se enfraquecem e, então, menos transações economicamente eficientes são efetuadas. Essas perdas ocorrem em detrimento, especialmente, do desenvolvimento econômico da sociedade.

A calculabilidade em relação às interpretações-padrão das normas, fixadas especialmente por meio de decisões judiciais de última instância, apresenta ainda outros reflexos no ambiente institucional e no mercado político-jurídico de tutela estatal dos interesses privados. Um Judiciário independente e previsível aumenta o valor pelo qual são cotadas as normas gerais e abstratas, pois aumenta a segurança de que, uma vez investido o montante de recursos - além de tempo e adesão de pleiteantes - necessários à aprovação junto ao Legislativo de uma regra jurídica que privilegie pequenos grupos, o Judiciário não sofrerá tantas pressões descentralizadas - e menos caras - para negar o cumprimento da decisão legislativa ${ }^{133}$.

É nesses termos que a Teoria Econômica do Direito, se assim reconhecida, reproduz na aplicação do Direito as mesmas prescrições que faz às instituições jurídicas como um todo. A adequação da maneira pela qual as regras gerais incidem sobre a realidade é avaliada de acordo com as conseqüências socioeconômicas que gera. Até por essa razão, a interpretação de normas deve deixar-se influenciar pelos conhecimentos econômicos, de maneira a que cumpra sua função maximizadora ao promover a eficiência possível dentro de limites pré-existentes na realidade social ou na própria regra que se aplica.

Nesse sentido, mais que re-inserir ponderações de caráter econômico e teleológico na apreciação judicial dos conflitos sociais, é preciso que isso se faça não só a fim de promover a eficiência em casos específicos, mas deve ter como objetivo o estabelecimento de instituições jurídicas estáveis, maduras e capazes de oferecer os melhores incentivos ao desenvolvimento econômico e social.

${ }^{133}$ MUELLER, Dennis. Public Choice. Cambridge: Cambridge University Press, 1979. p. 154. 
Não se trata, por suposto, de um objetivo que possa ser alcançado sem grandes esforços. Manter a estabilidade - vale dizer, calculatividade - das respostas jurídicas aos casos concretos pode significar, em alguns casos, a necessidade de conservar o Direito distante de ponderações econômicas, cuja aplicação poderia trazer mais custos em ambientes despreparados para uma aplicação economicamente mais sofisticada das normas.

Outra crítica relevante que se pode opor à adoção da eficiência como um valor a conduzir decisões judiciais, especialmente no que se refere ao sistema romanogermânico, é a inadequação sistêmica desse voluntarismo. O exercício do poder decisional pelos juízes estaria adstrito a limites, relacionados tanto à extensão dos fatos que se pode conhecer quanto aos valores que podem dirigir a decisão.

Em face disso, na ausência de previsão intra-ordenamento, legal ou constitucional, de que o juiz está legitimado a promover a influência da eficiência como um valor a guiar as alocações de bens e responsabilidades que decorrem de seu julgamento, este ficaria impossibilitado de se empenhar em atividades maximizadoras.

Essa é a posição de teóricos da Civil Law quando analisam a possibilidade de promoção da eficiência através de decisões judiciais. É o caso do alemão Eindenmüller, que acredita na necessidade de previsão normativa anterior para que o juiz se empenhe na tarefa de maximizar a utilidade, riqueza ou bem-estar sociais ${ }^{134}$.

Sem que se busque um fundamento possível,da eficiência em valores já positivados como a dignidade da pessoa humana ou liberdades individuais, o que se torna relevante nessa questão para o presente estudo é como a eficiência se apresentaria para o Direito positivo: dentro ou sobre ele ${ }^{135}$.

Nos textos de Richard Posner, é possível identificar uma certa ambigüidade, talvez simples indefinição, quanto a esse problema. Ele chega a apontar uma compatibilização entre seus postulados pró-eficiência e a kelseniana Teoria Pura do Direito. Para Posner, dentro dos parâmetros estabelecidos para a decisão judicial, das molduras, há espaço livre para que o juiz se deixe guiar por valores, inclusive a eficiência. Assim, esse autor afirma que, mesmo adotada essa teoria mais restritiva do Direito, seria possível reconhecer espaços de discricionariedade em que a eficiência

\footnotetext{
134 Para referido autor, mesmo o legislador estaria limitado pelos direitos fundamentais quando se dispusesse a promover a eficiência como um princípio jurídico. EINDENMÜLLER, Horst. Effizienz als Rechtsprinzip. 3a. ed. München, Mohr Siebeck, 2005. p. 486-487.

135 POSNER, Richard. Law, Pragmatism and Democracy. 2 ${ }^{\mathrm{a}}$. impressão. Cambridge: Harvard University Press, 2003. p. 250 e seguintes.
} 
pode influenciar a decisão sem que se rompa a adequação formal e sistêmica do Direito positivado da Civil Law.

Nesses termos, Posner coloca a eficiência como um valor sobre o Direito, mas que pode ser inserida em seu meio, se não através de ato legislativo, ao menos mediante influência sobre as decisões judiciais, dentro dos limites possíveis.

Outro grande óbice levantado contra a atuação pró-eficiência de magistrados é que o intérprete, mesmo quando se trate de um juiz economicamente engajado, precisaria de grande quantidade de informações para tomar decisões econômica ou socialmente ciosas, o que também é algo extremamente custoso. Assim, seria simplesmente indesejável o emprego de tantos recursos sempre que um novo tipo de conflito surgisse ${ }^{136}$.

Dessa maneira, tal qual a escolha necessária quanto ao nível de intervenção adequado do Direito no enforcement das normas, também quando do ato de interpretar e aplicar o Direito parece ser exigida uma escolha a respeito do quanto se deseja investir em informações para obter uma decisão mais adequada. Essa decisão, reafirmam os teóricos da Análise Econômica, pode ser iluminada pelo conhecimento econômico, mas pode vir a ter um caráter bastante político, vez que deve revelar o valor - vale dize, quanto se está disposto a pagar - para a manutenção de um aparato de boa qualidade que se empregue a interpretar e aplicar as regras da maneira mais eficiente possível.

${ }^{136}$ HANSON, Jon. HART, Melissa. Law and Economics. In: PATTERSON, Dennis (ed.). A Companion to Philosophy and Leal Theory. Malden: Blackwell, 2005. p. 328. 


\section{EFICIÊNCIA E MAXIMIZAÇÃO NA TEORIA ECONÔMICA DO DIREITO}

Nos capítulos anteriores, buscou-se demonstrar como o conhecimento econômico pode ser relevante quando da instituição e aplicação de normas jurídicas. Apresentou-se como a eficiência deve influir sobre a constituição do Direito e foi possível verificar que falhas estruturais nas instâncias nomogênicas permitem a geração de normas pouco eficientes - o que deve ser combatido.

No entanto, ainda não foram abordadas com profundidade as razões pelas quais a eficiência detém atenção privilegiada dessa Teoria Econômica do Direito. O presente capítulo tem o objetivo de explorar a argumentação dos teóricos pertinentes e demonstrar como a eficiência veio a se tornar um valor fundamental para uma teoria jurídica.

É preciso esclarecer as possíveis origens dessa perspectiva economicista e reconstruir a evolução do argumento ao longo do tempo. Para tanto, o presente capítulo começa por explorar como a unidade material de teorias maximizadoras evoluiu desde a utilidade benthamita do século XVIII até a noção de bem-estar ou riqueza, presentes nos mais recentes ensaios sobre o tema.

Será possível notar que há muito em comum entre a argumentação que era desenvolvida há séculos com o que há de mais contemporâneo no debate. Além de fazer uso de instrumentos maximizadores para proporcionar um bem maior às sociedades, esses autores mantiveram em comum a crença na necessidade da avaliação racional e meticulosa das decisões políticas e jurídicas.

Em seguida, busca-se investigar que fundamentos são postulados em defesa dos critérios maximizadores. Percebe-se, então, que há uma busca mais ou menos discreta por instituir razões legitimadoras à eficiência como valor.

Por fim, o estudo será no sentido de traçar as comparações existentes na teoria em análise acerca da relação entre sensos de justiça e a eficiência. Problematiza-se a crença plena na eficiência e alguns autores chegam a afastá-la como critério absoluto, mas até mesmo essa concessão parece se tratar de uma etapa de evolução da teoria que a torna mais abrangente e inclusiva, como se demonstrará.

Desde logo, enfatiza-se que a idéia de eficiência como axioma do Direito, tal como presente nessa Teoria Econômica do Direito, é um aspecto mais vinculado à 
análise normativa - e não positiva - das estruturas jurídicas. Deste modo, não se desenvolve expressivamente dentro da argumentação que descreve como o Direito é empiricamente constatável, mas se institui especialmente dentro do debate sobre como o Direito deveria ser a fim de atender aos postulados erigidos no âmbito da Análise Econômica do Direito e dar cumprimento à função socioeconômica do Direito.

\subsection{Maximização da utilidade, da riqueza ou do bem-estar}

Uma vez proposta a idéia de que eficiência é um meio, valor, segundo o qual deve se pautar o direito a fim de atingir sua função - a maximização - cabe definir com maior exatidão o que especificamente se objetiva maximizar.

Há pelo menos três vertentes que devem ser estudadas e dizem respeito à variável a ser maximizada: a da utilidade, a da riqueza e a do bem-estar. A importância de se avaliar a primeira delas tem fulcro histórico além de teórico, pois, como se verificará, há fortes indícios de que o utilitarismo clássico pode ter influenciado decisivamente as construções contemporâneas pertinentes à Análise Econômica do Direito. As duas vertentes seguintes, pregadoras da maximização da riqueza ou do bemestar, conformam o debate atual a respeito do tema, ambas com características distinguíveis, ainda que semelhantes.

O estudo dessa primeira tem importância muito além da histórica, já que conforma a base retórica sobre a qual as seguintes puderam evolui. Além disso, é fundamental para que se possa compreender e avaliar bem a terceira proposta de variável, já que a idéia de bem-estar, pode-se antecipar, é uma releitura da utilidade clássica.

Como já referido anteriormente, Jeremy Bentham (1748-1832) é reputado como fundador da Escola Utilitarista. Em pleno século XVIII, passou a desenvolver estudos que foram importantes na construção do Direito moderno. Sua proposta Ética Utilitarista é um dos primeiros intentos em analisar racionalmente as decisões políticojurídicas de maneira aperfeiçoar a atividade do Estado. 
Bentham acreditava que era preciso efetivamente reformar o Direito ${ }^{137}$, racionalizando-o mediante a avaliação das normas a partir de uma moral utilitarista. Em sua busca, esse autor acabou por deslocar da Natureza ao Soberano a atribuição de definir o conteúdo das regras jurídicas e, ao construir a idéia de que o Direito é fruto de uma decisão política, defendeu a necessidade de que tal decisão seja inspirada no Princípio da Utilidade ${ }^{138}$.

Partindo do pressuposto de que o ser humano é basicamente sujeito a dois senhores, a dor e o prazer, ele propõs o Princípio da Utilidade, critério com o qual seria possível julgar se qualquer comportamento é adequado ou não na medida em que for promotor ou constritor de maior felicidade para o maior número de afetados. Desde então, o tema da utilidade como unidade substantiva a se maximizar é recorrente.

No entanto, é preciso salientar desde logo que, para a Escola Utilitarista, essa utilidade se identifica com a felicidade, mas tem seu senso expandido a ponto de significar qualquer sorte de prazer, vantagem e bem.

Aliás, um outro elemento marcante da perspectiva benthamita do Direito que veio a se fixar como grande postulado da Análise Econômica do Direito é o Conseqüencialismo $^{139}$. Trata-se de uma abordagem teleológica a respeito do Direito, que deixa de se legitimar em razão de seus princípios estruturantes. A Escola Utilitarista postula a avaliação do Direito não segundo critérios formais e de coerência lógica interna, mas sim de acordo com os efeitos que a decisão jurídica é capaz de gerar na felicidade dos indivíduos.

Para Bentham, um observador neutro seria capaz de avaliar quaisquer decisões ou condutas e aferir se promovem a maximização da felicidade social. Para tanto, bastaria efetuar a soma das felicidades individuais atingidas. Sob o julgamento de tal mecanismo, seria possível avaliar casuisticamente as relações sociais e determinar que modalidades de condutas costumam gerar maior felicidade ao maior número de pessoas, individualmente consideradas. As relações promotoras da utilidade deveriam, segundo Bentham, ser promovidas pelo Direito em detrimento daquelas que gerassem dor ou obstruíssem o gozo dos prazeres.

\footnotetext{
${ }^{137}$ É importante lembrar que o Direito que Bentham buscava reformar era o inglês do século XVIII e tinha como seu principal debatedor Sir Blackstone, um defensor do modo tradicional - em termos weberianos: pré-moderno - de se produzir e aplicar o Direito.

${ }^{138}$ BENTHAM, Uma introdução aos Princípios da Moral e da Legislação, passim.

139 Para maiores informações do Conseqüencialismo na Filosofia Moral, vide KONOW, Which is the fairest of all? In: J. of Economic Literature, vol. XLI, 2003, p. 1200.
} 
A princípio, seria preciso a análise caso a caso para que se possa definir a adequação utilitarista da conduta ou decisão jurídica, o que certamente dificultaria a adoção desse Princípio como um guia efetivo das volumosas decisões tomadas dentro da sociedade. A solução para essa dificuldade deu-se com o desenvolvimento da idéia de "Rule Utilitarianism". Dessa maneira, o julgamento utilitarista sobre a ação ou decisão social não precisa ser verificada casuisticamente, mas é suficiente que a conduta sob análise seja, via de regra, geradora de maior utilidade para os indivíduos que compõem essa sociedade ${ }^{140}$.

O individualismo ${ }^{141}$, cuja presença marcante nas construções teóricas dos autores vinculados à Análise Econômica do Direito já se relatou, já se evidenciava na argumentação benthamita e de seus seguidores. No entanto, é preciso elucidar que, para o Utilitarismo, é a felicidade agregada da Sociedade que se tem em vista. Assim, o individualismo é fundamental para definir o conteúdo das preferências daqueles que compõem a sociedade, mas o resultado da consulta à moral utilitarista é, nesse sentido, coletivista $^{142}$.

Outra posição comum entre a Escola de Bentham e os autores da Teoria Econômica do Direito repousa sobre a observação que fazem do Direito sem, no entanto, preocupar-se em descrevê-lo estruturalmente. Em outros termos, o problema da validade das normas jurídicas não é tema privilegiado e o debate sobre a função do Direito tem maior prioridade. Desta maneira, tais autores constatam aquilo que se chama de Direito em determinado momento histórico e, a partir disso, constroem suas argumentações sobre as conseqüências do Direito posto - análise positiva - ou então tecem postulados sobre como e por quais razões o Direito deveria ser - análise normativa.

Apesar das posições comuns, mesmo autores da Análise Econômica do Direito rejeitam o Utilitarismo como antecessor imprescindível de seus postulados e críticas contra as observações de Bentham e seus seguidores são levantadas até mesmo por Richard Posner. Para esse autor, o Utilitarismo não conseguiu esclarecer os limites coerentes para a avaliação da felicidade do maior número de pessoas. Não teria ficado

${ }^{140}$ KOLM, Serge-Christophe. Modern Theories of Justice. Cambridge: MIT, 1996. p. 414.

141 Nos termos em que veio a se desenvolver nas ciências econômicas, ou seja, na figura do homos oeconomicus, conforme tratado no Capítulo $1^{\circ}$.

${ }^{142}$ Em outros termos, a satisfação dos indivíduos é o ponto de partida para a definição do conteúdo do julgamento utilitarista, mas é preciso que se maximize a utilidade da Sociedade para que se veja dada a chancela utilitarista à decisão jurídica ou política. KOLM, Idem, p. 413. 
claro, por exemplo, qual o universo de pessoas que é relevante na aferição da maximização da felicidade agregada ${ }^{143}$.

Outra crítica diz respeito à dificuldade de se quantificar o grau de felicidade gerado a partir de qualquer intervenção jurídica na realidade socioeconômica; segundo esse mesmo autor, não há meios adequados para verificar a alteração da felicidade de um indivíduo em relação da mudança no grau de satisfação de outro indivíduo.

As críticas a respeito dos postulados utilitaristas foram intensas, mas não impediram que os primeiros escritos de Bentham influenciassem as primeiras gerações de economistas, que já herdavam de Smith a idéia do ser humano como agente maximizador de suas satisfações.

Até mesmo em razão disso o termo utilidade continuou a ser utilizado pela teoria econômica, aproximando-se do debate a respeito do valor e identificando-se em larga medida com bens e serviços, amplamente considerados. Nesse senso, tornou-se elemento integrante dos modelos e das construções científicas que conformam a Economia Clássica e, até mesmo depois da evolução marginalista, era possível reconhecer facilmente nos trabalhos Neoclássicos traços dos primeiros ensaios utilitaristas.

No entanto, é preciso esclarecer que, no que se refere ao debate de fundo moral, esse senso de utilidade, puramente econômico, teve apenas mediata influência nas argumentações, vez que geralmente passa a figurar na doutrina de maneira alterada, sob o termo de bem-estar (welfare), como se explanará.

As premissas do Utilitarismo se assentam em larga medida nas preferências dos indivíduos. Aliás, para a medição da satisfação individual - necessária a praticamente qualquer métrica de maximização - as preferências dos indíduos é relevante e parte de dois axiomas muito simples: (i) quando há indiferença entre duas diferentes situações, elas possuem o mesmo valor, e (ii) se certo indivíduo prefere e os demais são indiferentes, já se configura uma situação de maior valor.

No entanto, nem mesmo sua simplicidade a livra de críticas. Como já explorado, não há meios seguros de se objetivar o vigor das preferências individuais, o que dificulta uma análise economicamente ciosa das decisões político-jurídicas que

\footnotetext{
143 "A política americana deveria maximizar a felicidade do povo americano, ignorando a felicidade de estrangeiros? (...) E quanto às gerações futuras?”. POSNER, Economics of Justice, p. 51.
} 
interferem na realidade socioeconômica. Se a medição da utilidade extraída depende da objetivação do nível de preferência, instala-se grave problema ao analista utilitarista.

Ao tentar se furtar de algumas críticas julgadas pertinentes contra o Utilitarismo, Posner buscou solucionar alguns de seus problemas técnicos mediante o uso de outra unidade métrica a se maximizar. Deixou a noção de utilidade e passou a postular a riqueza como variável a ser promovida através do Direito - trata-se da segunda vertente a ser explanada.

Quando analisa a relação de ruptura ou continuidade entre o utilitarismo e a proposição maximizadora de Richard Posner, Coleman afirma:

...Richard Posner oferece o sistema da maximização da riqueza como uma alternativa tanto para a teoria moral utilitarista como para a eficiência de Pareto. A maximização da riqueza seria um princípio moral mais atrativo que o utilitarismo e substituiria o critério de Pareto... ${ }^{144}$

Para Posner, a regra de maximização da riqueza configura uma base mais sólida e objetiva para a estruturação de um critério de avaliação do grau de adequação das condutas individuais e das decisões políticas e jurídicas, pois não sofreria dos defeitos encontrados em critérios anteriores, repletos de subjetivismo ${ }^{145}$.

Esse autor acredita que, uma vez que a riqueza é algo passível de quantificação, o mecanismo de aferição da maximização torna-se menos especulativo, e muito menos dependente de conjecturas sobre questões subjetivas.

De fato, não restam dúvidas de que a riqueza, medida através da moeda circulante, pode ser um parâmetro apropriado, já que viabiliza não só o cálculo e verificação das transformações do agregado, mas também facilita a exata compensação daqueles que se viram em situação pior em face da decisão jurídica ou política, quando for o caso.

Em outros termos, a efetiva compensação ex post, postulada pelo critério Kaldor-Hicks em sua evolução mais exigente, torna-se relativamente mais simples, já que não há qualquer necessidade de avaliar questões mais subjetivas, como a perda

\footnotetext{
${ }^{144}$ COLEMAN, Jules. Efficiency, utility and wealth maximization. p. 520.

${ }^{145}$ POSNER, Economics of Justice, p. 48.
} 
utilidade ou, em outros termos, avaliar a o vigor das preferências sobre o que se perdeu com a mudança efetuada.

Segundo Posner, as utilidades a que se referia Bentham podem ser de alguma maneira convertidas em valor corrente, já que explícita ou implicitamente participam de um mercado. Os mercados seriam, portanto, capazes de expressar o valor de quaisquer benesses, mesmo quando se tratarem de mercados hipotéticos ${ }^{146}$.

No entanto, parece razoável o argumento de que riqueza, por mais direta e prática que seja sua noção, nem sempre se identifica com utilidade gozada, com satisfação ou bem-estar individual. Dessa forma, os estudos mais recentes sobre o tema retornam ao uso de um conceito que, ainda que menos objetivo que a riqueza, oferece sua amplitude como vantagem comparativa. A maximização do bem-estar é a terceira vertente a ser estudada ${ }^{147}$.

O bem-estar contém a noção de utilidade, mas a amplia de modo a identificar-se com qualquer felicidade, seja do gozo de bens em um extremo, como da satisfação em face da felicidade alheia em outro, ainda que sobre a busca dessa última paire a recomendação de maior cautela. É um conceito não excludente que inclui em seu bojo inclusive preocupações distributivas, na medida em que essa distribuição possa afetar positivamente o bem-estar agregado.

Como sumariam seus principais autores ${ }^{148}$, será relevante para a avaliação da adequação de uma decisão jurídica tudo que for importante para o bem-estar dos indivíduos e, de outro lado, será ignorado tudo que não importar ao bem-estar dos indivíduos. Assim, libera em absoluto às preferências individuais o julgamento quanto à qualidade de políticas ou regras - mesmo quando tais preferências se mostrarem estranhas ou irracionais em alguma medida ${ }^{149}$.

Perante essa nova vertente, o aspecto coletivo da agregação de bem-estar é mais explorado. Isso não significa, no entanto, que o indivíduo perde sua posição central perante a sociedade como organismo diferenciado. Essa proposta, que postula a maximização do bem-estar, também apresenta uma metodologia individualista na estimativa da adequação de decisões jurídicas e políticas. De maneira muito semelhante

\footnotetext{
${ }^{146}$ POSNER, Economics of Justice, p.63.

${ }^{147}$ KAPLOW, SHAVELL, Fairness versus Welfare. Harvard Law Review, vol. 114, nº. 4, fevereiro de 2001.

148 KAPLOW, SHAVEL, Idem, p. 16.

149 A idéia de bem-estar pode, inclusive, incorporar uma valoração desproporcional e irrazoável que um indivíduo possa dar aos riscos, por exemplo. Quase nada escapa a esse termo inclusor. Ibidem, p. 19.
} 
ao que ocorre na aferição da maximização da riqueza, o bem-estar agregado nada mais é do que a soma do bem-estar individual daqueles afetados pela mudança ou transação. A diferença substancial que há é que pode se referir a absolutamente todos os afetados, ainda que de maneira muito discreta e indireta.

Para Kaplow e Shavell, trata-se da adoção de uma posição moral segundo a qual as regras jurídicas serão avaliadas exclusivamente de acordo com seu efeito junto ao bem-estar dos indivíduos, segundo métodos de agregação próprios ${ }^{150}$.

Apesar se tratar de uma concepção mais flexível, capaz de lhe dar melhor com problemas que surgem como em situações nas quais o respeito a uma noção de justiça ineficiente é valorado pelos indivíduos, não há substancial ruptura entre esta proposta maximizadora e as anteriores. Não se trata, esta última vertente, de uma proposição absolutamente contrária às duas anteriores.

A noção de bem-estar surge como uma releitura da utilidade clássica e não nega que o uso de variáveis como a riqueza pode ser útil. A crítica que mantém contra a métrica da riqueza agregada paira sobre a concepção de que o uso de grandezas pecuniariamente expressas não teria, como defendido por Posner, essa capacidade de objetivar a satisfação - vale dizer, o valor - que diferentes indivíduos são capazes de extrair dos mais variados recursos. Nesse ataque, Shavell e Kaplow são acompanhados por Calabresi, que chega a classificar de "peculiar, para não dizer absurda, a relação entre a riqueza e a utilidade" 151 .

A grande capacidade inclusiva da idéia vinculada a "bem-estar", no entanto, teria maior flexibilidade para captar a satisfação dos indivíduos distintamente considerados, ainda que tornasse pouco mais problemática a aferição da maximização de qualquer decisão praticada. Por essa sua maleabilidade, no entanto, teria maior capacidade de assimilar grande parte das críticas e problemas que são opostos aos argumentos anteriores - utilidade clássica e riqueza - e conseguiria aglutinar diferentes conceitos sob essa nomenclatura bastante ampla.

No entanto, essas suas características não evitam críticas relacionadas aos componentes que a compõem e é usual a crença de que se trata uma involução da idéia de maximização de riqueza, pois proporcionaria maior dificuldade de avaliação das realocações efetuadas e seria, portanto, menos adequada como instrumento de análise.

\footnotetext{
${ }^{150}$ Fairness versus Welfare. Harvard Law Review, p. 986.

151 CALABRESI, An Exchange, p. 556.
} 
De fato, ao ampliar sua capacidade integradora, a concepção de maximização de bemestar perde certa objetividade e parece se tratar apenas de uma reutilização da teoria utilitarista clássica, sob nova denominação e alguma inovação para elidir-se de velhas críticas ao antigo modelo do século XVIII.

Além disso, torna o discurso maximizador em uma retórica mais palatável, de fácil percepção e maior aderência às políticas sociais que, desde a metade do século XX, se fazem presentes em especial dentro da Política e do Direito, propriamente as instâncias sociais cujas decisões os postulados maximizadores pretendem prioritariamente influenciar.

\subsection{Consenso como fundamento último para a Eficiência}

Ainda que não seja exatamente uma preocupação explícita e recorrente dos autores vinculados à Análise Econômica do Direito, é possível delinear tentativas de corroborar a eficiência como um valor segundo mecanismos outros, que lhes forneça maior Legitimação.

Dos modelos de mercado, autores da Teoria Econômica do Direito extraem a idéia de que transações só são efetivadas quando se estabelece o consenso entre os envolvidos no que se refere a valores e conteúdos do trato. Como toda utilidade pode ser testada em mercados hipotéticos - e assim valorada as disposições para ofertála e adquiri-la - as decisões podem fazer uso desse instrumento hipotético e, aplicando-o à situação em análise, conferir que soluções seriam encontradas mediante transações de um mercado ideal e, então tentar reproduzir o arranjo na realidade.

Presume-se que, desde que os indivíduos reais guardem alguma semelhança com o indivíduo, conforme descrito pela Escola Neoclássica, se construiria um consenso que se assentaria nesse resultado de mercado.

Assim, a idéia de eficiência como um parâmetro moral a julgar a qualidade das decisões políticas e jurídicas poderia ter como fundamento último o consenso hipotético que indivíduos racionais dariam caso de fato estivessem transacionando em mercados perfeitos ${ }^{152}$.

152 "Law and Economics busca oferecer uma base para a decisão fundada no consenso. O ponto de partida é: pessoas diferentes têm distintos desejos, objetivos e valores, mas todos concordariam que seria 
Nesse sentido, como já indicado, não é raro observar o uso do critério paretiano de eficiência como um fator que, uma vez satisfeito, não gera quaisquer possibilidade de contestação ou resistência racional. Parte-se da crença de que, uma vez que nenhum dos afetados tenha sido deixado em situação pior, não há motivos racionais para que obstrua ou refute a adequação daquilo que é realizado.

No entanto, é difícil a satisfação do critério de Pareto ${ }^{153}$, já que decisões políticas e jurídicas geralmente afetam terceiros de maneira pouco reconhecível, proporcionando externalidades negativas por vezes de difícil rastreamento.

Em face dessa limitação - e outras - desenvolveram-se outros argumentos legitimadores da eficiência como axioma a ser aplicado pelo Direito. Dentre eles, em especial a afirmação de que há um consenso subjacente e implícito quanto à aplicação da desse conceito econômico como critério valorativo, mesmo levando-se em conta o problema dessa aceitação no tempo, o que envolveria temas como o risco e expectativas individuais.

O argumento é apresentado, principalmente, por Richard Posner. Novamente, parte-se da concepção de que o indivíduo busca sempre maximizar sua satisfação e riqueza, conclui-se que, sempre que transações forem efetuadas voluntariamente, as partes terão consentido nas conseqüências da decisão. Assim, mesmo em face da incerteza quanto ao futuro, a aceitação racional ex ante daquilo que a médio ou longo prazos poderá resultar das modificações alocativas bastaria para que se desse a satisfação indireta do critério paretiano - ou melhor, cumpre um critério de aceitação racional dos termos em que a transação se deu e arriscou-se a perdas em função da expectativa de ganhos futuros ${ }^{154}$.

Nessa perspectiva, ainda que qualquer indivíduo se veja em pior situação momentaneamente, ele mantém uma expectativa de compensação no longo prazo, pois espera que as maximizações da riqueza agregada que se instituem no presente lhe beneficiarão, pessoalmente, em momento posterior. Por essa razão, consensualmente se disporia a perdas passageiras em benefício da maximização do resultado social. Posner, portanto, fundamenta-se na aceitação de se dispor a uma situação possivelmente danosa,

melhor satisfazer esses desejos que não satisfazê-los, e prefeririam que isso ocorresse com maior freqüência do que com menor.” BIX, Jurisprudence, p. 191

153 Como mais explorado no Capítulo 2 do presente trabalho.

154 POSNER, Economics of justice, p. 88. 
mas compensadora de maneira agregada, e identifica esse essa acolhida, hipotética, com um consenso presumível, o que é visto com desconfiança por alguns autores ${ }^{155}$.

Vale dizer que esse viés, em que alguma perda individual é razoável em face de um ganho agregado compensatório - mesmo individualmente - já configura uma evolução nos termos professados pela economia liberal clássica. Lembre-se que, segundo essa corrente original, a eficiência somente poderia ser afirmada e o consenso presumível reconhecido quando nenhum dos indivíduos pudesse alegar a sua transição para situação pior em função da realocação de recursos ou quanto houvesse a adequada compensação logo após a maximização. Assim, a justificativa exigida dentro de um paradigma estritamente individualista de curto prazo seria a de que a decisão social, jurídica e política, seja neutra ou promotora do interesse de cada uma das partes que compõem a sociedade ${ }^{156}$.

Deste modo, a diminuição das exigências de caráter individualista para a caracterização do consenso hipotético efetuou transição juntamente com o critério de eficiência que se fazia hegemônico e partiu de um modelo paretiano para um compensatório potencial ou efetivo de longo prazo.

É preciso esclarecer que, especialmente no que se refere à compensação potencial de longo prazo, a expectativa do indivíduo é fundamental no processo de consentimento e, portanto, deve ser analisada.

Quando da decisão quanto ao desenho da norma, especialmente se os indivíduos não tiverem segurança sobre como a norma virá a incidir sobre sua vida - se ele será o tutelado ou o responsabilizado, por exemplo - fica caracterizada a circunstância ideal para que se alcance um amplo consenso entre os indivíduos de que a melhor regra a se instituir é aquela que maximiza a riqueza ou bem-estar de todos. Isso porque, para cada indivíduo, é melhor a adoção de regras gerais promotoras da eficiência, mesmo que eventualmente um deles se veja posteriormente prejudicado pela criação da norma.

Ocorre que, antes de efetivamente saber se é beneficiário ou penalizado pela instituição de determinada norma, o indivíduo poderá traçar racionalmente os custos e benefícios decorrentes das regras a se normatizar ${ }^{157}$.

${ }^{155}$ COLEMAN, Jules. Efficiency, utility and wealth maximization, p. 535-536.

156 COLEMAN, Jules. Risks and wrongs. Oxford: Oxford University Press, 2002. p. 29.

157 Exemplo comum é a da escolha de responsabilidade objetiva ou culposa em face de acidentes de trânsito. Desde que o indivíduo seja consultado antes que venha a figurar como ou gerador de dano ou 
Uma vez escolhido a melhor configuração da norma, o indivíduo se dispõe a, casualmente, figurar no pólo prejudicado e aceita tal condição na esperança de que, tratando-se do modelo normativo mais adequado e maximizador, vir a ser beneficiado em maior grau pela norma quando vier a figurar no pólo oposto. Ou então receber mais benefícios globalmente, de todas as normas outorgadas que busquem a eficiência.

Sem dúvidas, trata-se do resultado de um mecanismo de decisões baseadas em expectativas em que, incapacitado de verificar previamente sua condição perante a norma, o indivíduo tende a optar pela configuração que beneficia mais os agraciados e prejudica menos os penalizados, o que parece ocorrer quando da instituição de regra maximizadora do bem-estar ou riqueza agregados quando há maior aversão ao risco.

Eis então como se estabelece, especialmente nos trabalhos de Posner, a noção de que há um consenso subjacente que legitima, ainda em termos bastante liberais, a busca pela sempre maior eficiência nas relações interindividuais sobre as quais incide o Direito.

Essa concepção, no entanto, não resta livre de opositores. Dworkin estabelece uma crítica às colocações a respeito da consistência do argumento que promove o consenso ao patamar de legitimador da eficiência como valor. Segundo esse autor, esse consenso, que não se pode efetivamente observar na realidade social, deveria ser demonstrado ao menos teoricamente. Então, afirma que, diferentemente de Rawls ${ }^{158}$, Posner não teria se dedicado a desenvolver um arrazoamento convincente capaz de atribuir valor legitimador à sua proposição de consenso ex ante $e^{159}$.

Não se satisfaz, assim, com o uso que Posner faz dos mecanismos de mercado - modelos ideais, vale dizer - como expressão de qualquer modalidade factível de vontade.

vítima, ele optará pelo desenho normativo que for mais eficiente de maneira agregada, ainda que venha a ser negativamente afetado pela norma quando instituída.

${ }^{158} \mathrm{O}$ consensualismo de Rawls será tratado no próximo item deste estudo.

159 Dworkin desconfia da defesa de Posner sobre o consenso relativo às regras do jogo, através do qual cada indivíduo se disporia a eventualmente se ver em pior situação, desde que anteriormente tivesse vislumbrado a possibilidade de maximização agregada naquela configuração alocativa de direitos ou responsabilidades. DWORKIN, Ronald. Why efficiency? Hofstra Law Review. Vol. 8, p. 563-590, 1979-1980. p. 575. 


\subsection{Sensos de Justiça e a eficiência como valor}

A relação entre as noções mais usuais de justiça e aquelas apresentadas no âmbito da Análise Econômica do Direito é bastante controversa. Os autores relacionados a esta teoria geralmente atacam, com fundamentos diferentes, outros sensos de justiça que se não se identificam com absoluta perfeição àqueles mecanismos maximizadores que postulam em suas obras.

Calabresi, por exemplo, reconhece o trade-off que existe entre a maximização da riqueza e a distribuição dessa riqueza. Contrariando os argumentos de Posner de que a perda de eficiência ataca sobretudo a riqueza dos menos favorecidos, Calabresi recorre ao contexto social para afirmar que em muitas circunstâncias a busca pela riqueza agregada pode significar a concentração desse excedente nas mãos de pequena parcela de indivíduos ${ }^{160}$.

Para Posner, no entanto, a vinculação estrita a princípios morais outros sem que se faça uma investigação das conseqüências resultantes de sua aplicação faz pouco sentido de um ponto de vista prático. Segundo ele, a utilização dos mecanismos de maximização da riqueza através da preocupação com a eficiência das regras é mais vantajosa, já que possibilita o uso ponderado e otimizado de axiomas como a autonomia e a liberdade, subsídios comuns de outras teorias da justiça ${ }^{161}$.

Além disso, mesmo no que se refere a um senso mais prático de justiça, o critério maximizador de riqueza teria vantagens sobre o utilitarismo tradicional, uma vez que os postulados de Posner baseiam-se nos modelos de mercado, onde as relações presumidamente ocorrem somente quando há aceitação pelas partes envolvidas - mesmo que em hipótese e, ademais, prescinde da medição da satisfação decorrente da utilidade.

Essa aceitação, afirma o autor, ainda que de fato possa não atingir a todos os afetados por uma determinada decisão, é capaz de conferir maior respeito e compatibilidade com os tão aclamados princípios libertários.

O utilitarismo, relativamente mais subjetivo, abriria espaço para que terceiros decidam acerca da felicidade que quaisquer mudanças causam nos indivíduos, viabilizando moralmente o paternalismo e afastando o respeito à autonomia da vontade e

160 CALABRESI, Guido. An Exchange: about Law and Economics: a letter to Ronald Dworkin, p. 558.

${ }^{161}$ POSNER, Economics of justice, p. 65 e seguintes. 
da liberdade. Isso não ocorreria no caso da adoção da maximização da riqueza como fundamento, pois a subjetividade é afastada com a quantificação objetiva das benesses e é o próprio indivíduo que, mediante atuação voluntária junto aos mercados, expressa o valor pertinente ao cálculo da maximização agregada.

Já para os defensores da maximização do bem-estar, o ataque às demais noções de justiça mantém o alvo na fundamentação dos demais princípios. Afirma-se que os sensos predominantes são baseados em constatações ditas auto-evidentes, válidas por estarem de acordo com instintos, o que não daria parâmetro mais amplo e seguro que o da maximização de bem-estar, já que este se foca em absoluto na promoção dos indivíduos.

Haveria casos em que as soluções trazidas pelos demais princípios de justiça seriam coerentes com a maximização do bem-estar, mas os autores dedicam-se a relatar outros em que a aplicação estrita e não racionalizada de alguns sensos de justiça levaria todos os envolvidos a uma situação pior ${ }^{162}$.

Isso decorreria principalmente do fato de que as noções mais comuns de justiça exigem a preservação de princípios de maneira absoluta e sua aplicação se restringe a observar parâmetros lógicos e de coerência interna, sem, no entanto, investigar de maneira mais extensa as conseqüências últimas na realidade sobre a qual se intervém.

No entanto, mesmo a relação entre o critério de maximização do bemestar e o senso de justiça pode ser problematizada quando, em face das preferências individuais, um senso de justiça não maximizador é parte integrante do bem-estar. Explica-se: muitas são as vezes em que dentre as preferências que compõem o bem-estar do indivíduo está a necessidade de que um determinado senso de justiça seja aplicado ou então um princípio moral não maximizador seja respeitado. Nesses casos, mesmo que a utilização dessa ineficiente noção de justiça fosse rejeitada per se, deveria ser considerada como parte integrante das preferências individuais e, como tal, possível maximizadora do bem-estar agregado.

Partiria-se, assim, a uma análise de custo-benefício, em que pode-se aceitar o respeito a uma aplicação ineficiente de idéia de justiça desde que os malefícios sócio-econômicos não superem o valor que se dá a sua aplicação. Em outros termos, para a Teoria Econômica do Direito, pode ser desejável a aplicação de sensos não

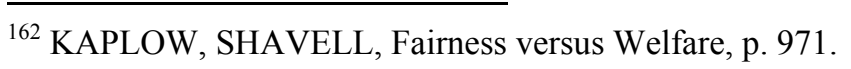


economicistas de justiça, desde que o custo de sua aplicação seja menor do que as ineficiências que causa - grosso modo, deve-se determinar quanto os indivíduos estariam dispostos a pagar para que uma dada "justiça" se efetivasse ${ }^{163}$.

Dessa maneira, esse mesmo mecanismo inclusor pode ser adaptado ao critério da maximização da riqueza na medida em que o indivíduo se disponha hipoteticamente a pagar por ver respeitado determinado princípio ou executado um específico senso de justiça. Destarte, se expressa o valor, quase pecuniário, que a utilização de instrumentos não maximizadores têm para o indivíduo e, portanto, é possível que tal valor seja ponderado quando da avaliação da maximização da riqueza agregada.

Essa capacidade de abrangência das regras maximizadoras torna possível a conciliação entre aqueles que vêem na justiça e no Direito uma função predominantemente distributiva.

A fim de compor um quadro mais completo a respeito da relação entre critérios morais maximizadores, o problema da eficiência e a noção de justiça como distribuição, é preciso demonstrar os argumento de Rawls, freqüentemente presentes nos debates com autores de Law and Economics.

Rawls desenvolve um princípio a guiar as decisões políticas e jurídicas que denomina maximin. Segundo suas proposições, se os indivíduos fossem capazes de negociar que alocação de recursos acreditam ser a ideal, sem, no entanto, terem conhecimento a respeito de suas preferências, dos interesses dos grupos que integram e de que posição ocupam na sociedade, ou seja, sob o "véu da ignorância", os indivíduos decidiriam, sim, por decisões maximizadoras. Entretanto, também demandariam mais ampla distribuição de recursos, já que, a priori, desconhecem suas condições e preferências individuais e, assim, decidiriam por oferecer um mínimo de recursos e tutela aos menos favorecidos ${ }^{164}$.

Rawls é identificado algumas vezes como utilitarista, ainda que dessa Escola guarde certas distinções argumentativas - Rawls preocupa-se tanto com a

\footnotetext{
163 Não se trata de uma aquisição instrumental recente. Pareto, já em seu Tratado de Sociologia Geral, tratou da diferenciação entre a utilidade direta que os indivíduos ou comunidades podem usufruir por si e aquela utilidade que podem receber em função da satisfação que lhe traz o benefício de outros indivíduos e comunidades.

164 .FARREL, Martín Diego. Filosofía del Derecho y Economia. Buenos Aires: La Ley, 2006. e também FREEMAN, Samuel (ed.). The Cambridge Companion to Rawls. Cambridge: Cambridge University Press, 2005.
} 
liberdade quanto com uma certa igualdade de oportunidades. ${ }^{165}$ De qualquer forma, seus argumentos acerca da adoção critérios morais maximizadores diferem em maior grau do princípio da maximização da riqueza, pois enquanto Rawls faz uso de uma retórica mais puramente filosófica que toma por base a racionalidade genérica dos indivíduos, Posner e os demais autores da estudada construção normativa economicista sobre o Direito fundam seus argumentos em modelos econômicos que informam uma figura específica do indivíduo - homos oeconomicus. Para ambos, no entanto, há o compartilhamento de um elemento comum, já que levam o debate a respeito da racionalidade em decisões até a exercícios de negociação e consenso hipotético entre indivíduos.

O debate entre Posner e Rawls, no entanto, se coloca ao final como relativamente harmônico no que se refere aos instrumentos argumentativos utilizados, já que, para Posner, a proposta de Rawls somente promove a inclusão de uma outra variável ao uso posneriano de mercados hipotéticos, qual seja a aversão ao risco.

Sem saber previamente suas preferências e interesses de grupo, sob o "véu da ignorância", os indivíduos optariam por estabelecer um critério mais distributivo, sim, mas não em função do altruísmo que pode parecer. Trata-se de um custo que os indivíduos estão dispostos a pagar para se securitizarem e evitar situações de carência de recursos ou tutela. Ocorre que - segundo uma leitura posneriana - os indivíduos-tipo utilizados por Rawls temem o risco e, portanto, forçam um desconto maior em tempo presente - preferem receber menos, mas estarem seguros de algo receberão.

Assim, parece haver entre esses autores apenas uma diferenciação quanto ao momento de avaliação das preferências individuais. Enquanto Rawls propõe que se façam hipoteticamente enquanto os indivíduos são ignorantes de suas predileções específicas, Posner parte dessas predileções para sugerir que a escolha seja feita em termos de disposição a pagar para que essas se vejam satisfeitas.

Das formas apresentadas, ideais de justiça não maximizadores podem sensibilizar o princípio moral da eficiência, mas o fazem de maneira parcial e sempre de acordo com os critérios erigidos pela própria metodologia econômica, ou seja, esses outros ideais passam por um processo de valoração.

165 SILVA, Marcos F. Ética e Economia: impactos na política, no direito e nas organizações. São Paulo: Elsevier, 2007. 
Isso se dá, no entanto, sem que se deixe de avaliar as conseqüências socioeconômicas que a satisfação de ímpetos distributivos têm a médio e longo prazo. Nesse sentido, os critérios maximizadores avalizariam intervenções que operassem a redistribuição dos recursos de maneira a atender às crenças e valores predominantes na sociedade.

No entanto, paralelamente, deveria ser promovido o esclarecimento a respeito dos resultados possíveis de quaisquer interferências do gênero com a finalidade de excluir das preferências individuais a necessidade de que sensos de justiça não maximizadores sejam respeitados.

Nesses termos, Law and Economics e a idéia da eficiência como um valor a ser perseguido pelo Direito, afirma Calabresi, é apenas uma parte do caminho em direção ao fim almejado: a efetivação da justiça. Aspectos distributivos baseados em outros valores podem ser a outra parte do caminho, uma vez que podem ser combinados segundo as preferências dos indivíduos em cada tempo e cada sociedade, de maneira a promover a melhoria das condições de vida agregada ${ }^{166}$.

Ele vai além e afirma que, uma vez que a eficiência é, para ele, um instrumento em busca da justiça, a noção de justiça deve ser utilizada como um veto, um limite absoluto a obstar tentativas maximizadoras quando estas divergem desse objetivo. Parafraseando o autor, é possível sumariar sua posição: o caminho - eficiência, ou então a distribuição - deve ser abandonado quando não efetiva sua finalidade última.

Dworkin diagnostica nessa posição de Calabresi o uso não exatamente explícito da idéia de maximização da riqueza como um valor e revela a necessidade de uma correção. Se há de fato um trade-off entre a distribuição e maximização, significa que só faz sentido vê-lo como uma escolha a ser ponderada se ambos possuírem algum valor - em termos filosóficos, neste argumento de Dworkin - que lhes é próprio e que se excluem entre si.

Tanto a eficiência como a distribuição, no argumento de Calabresi, possuiriam uma importância social que se esgotaria em suas próprias qualificadoras, pois só assim faz sentido prezar pela manutenção de uma quando a outra, que tem valor reconhecido, deve ser excluir a primeira para se ver elevada. Em outros termos, Dworkin argumenta que se a eficiência não fosse um valor em si para os autores de Law and

166 CALABRESI, Guido. An Exchange: about Law and Economics: a letter to Ronald Dworkin, p. 560. 
Economics $^{167}$, a distribuição poderia ser priorizada ao extremo, desde que uma dada sociedade reconhecesse a isonomia como um valor relevante.

Como Calabresi prega que deve haver uma combinação entre eficiência e distribuição, conforme a melhor configuração em uma dada circunstância, estaria atribuindo um valor intrínseco a ambas.

Isso, no entanto, não seria coerente com a já exposta idéia do veto que se reserva à justiça quando da busca pela eficiência. Se a eficiência também é um valor em si, regrar o esforço por sua efetivação segundo critérios de justiça seria esvaziar em completo um valor em face desse outro, revestido pela concepção de justo.

Nesse sentido, seriam mais coerentes Posner, Kaplow e Shavell, que mantém a prescrição da eficiência - que tratam como valor - mesmo em face de indivíduos que revelem preferências também por valores alternativos, ainda que admitam, eventualmente e com pesar irresignado, que a combinação entre valores pode ser vista como adequada nos limites do contexto social que se observa, ainda que não seja o ideal segundo seus respectivos parâmetros.

167 No trabalho em questão, ele está se referindo especificamente a Dworkin, mas esse diagnóstico pode ser bastante adequada para muitos dos autores cujos pensamentos foram apontados no presente estudo, em especial Posner, Shavell e Kaplow. 


\section{CONCLUSÃO}

A pesquisa se desenvolveu com a finalidade de investigar textos de autores relacionados à denominada Law and Economics e determinar se, em seus trabalhos e debates, havia elementos suficientes para afirmar o desenvolvimento gradual e de autoria coletiva de uma Teoria Econômica do Direito.

Muitos sinais encontrados ao longo das leituras apontaram nesse sentido. $\mathrm{O}$ fato de que temas usualmente jurídicos foram tratados de maneira peculiar, economicista, leva a crer na possibilidade de que, efetivamente, essas perspectivas expressadas acerca do Direito conformem, reunidas, uma teoria jurídica propriamente dita, distinguível de outras através do modo idiossincrático através do qual se estabelece, com instrumentos conceituais e referenciais econômicos ainda não vistos de maneira tão sistematizada dentro dos debates jurídicos.

A certeza a respeito do efetivo desenvolvimento de uma Teoria Econômica do Direito não pode se dar, no entanto, de maneira absoluta. Em outros termos, não se dá univocamente em face das mais diversas concepções a respeito do que caracteriza uma teoria jurídica. No entanto, bem ao modo dos autores da Análise Econômica do Direito pragmática e funcionalmente - parece ser possível, sim, encontrar nos textos estudados uma teoria a respeito do Direito, economicista, que se coloca no debate jurídico contemporâneo.

Seus debates parecem ter se desenvolvido a partir de abordagens pontuais de problemas jurídicos, mas, ao longo do tempo, os trabalhos se desenvolveram e foram sistematizados, ganhando relativamente elevado nível de abstração teórica. Chegam, inclusive, a estabelecer um viés normativo em relação à constituição e aplicação das regras jurídicas.

Além disso, é possível reconhecer que, se de fato tal teoria pode ser apontada como existente, ela tem um fundamento moral bastante explícito, qual seja alguma idéia de eficiência como mecanismo maximizador de utilidade, riqueza ou bem-estar. Subjacente a essa moral é razoável apresentar o consenso - ainda que presumível ou hipotético - como elemento legitimador das intervenções jurídicas nas relações interindividuais, expressão essa de um discurso político inegavelmente liberal. 
Fazendo uso da comum distinção entre os trabalhos vinculáveis à Análise Econômica do Direito, seria possível ainda afirmar que a vertente descritiva, denominada positiva, fortemente empirista, teria como seu principal axioma a figura do homos oeconomicus, que utiliza como ponto de partida para suas observações. Suas características, talvez, tornem mais difícil sua qualificação como uma teoria propriamente jurídica.

Já a vertente prescritiva estaria mais consoante a um senso menos especulativo de teoria jurídica, já que a normatividade que carrega, assentada sobre um discurso moral baseado na eficiência, exibe maior identidade com o que usualmente se espera encontrar no discurso de uma teoria jurídica. Eis que, no que se refere a esses argumentos, normativistas, torna-se mais plausível a configuração de uma Teoria Econômica do Direito fundada no axioma da eficiência.

De certo, o presente estudo não esgota em absoluto as questões relacionáveis ao debate acerca da existência de uma Teoria Econômica do Direito e nem mesmo estabelece todas as problematizações a respeito da eficiência como um valor moral a ser perseguido pelo Direito. De fato, a pesquisa parece ter sido apta a apontar uma grande variedade de temas a serem investigados pormenorizadamente em outras oportunidades.

De qualquer forma, imagina-se que tenha sido capaz de modestamente contribuir no debate acerta de obscuridades pouco investigadas a respeito de como os estudos da Análise Econômica do Direito se integram dentro do debate mais amplo a respeito do Direito, especialmente no que se refere à descrição de suas características, definição de suas funções e exploração de suas técnicas interventivas na realidade socioeconômica. 


\section{REFERÊNCIAS BIBLIOGRÁFICAS}

ALPA, Guido et al (orgs.). Analisi Economica del Diritto Privato. Milano: Giuffrè, 1998.

ATIYAH, P. S. An introduction to the law of contract. 5th. ed. New York: Oxford University Press, 1995.

ATIYAH, P. S. Law and Modern Society. 2nd. ed. New York: Oxford University Press, 1995.

BACHRACH, Peter. Crítica de la teoria elitista de la democracia. Buenos Aires, Amorrortu, 1967.

BARZEL, Yoram. A theory of the State: economic rights, legal rights and the scope of the State. Cambridge: Cambridge University Press, 2002.

BECKER, Gary. Crime and Punishment: An Economic Approach. The Journal of Political Economy. Vol. 76. No. 2. Março-Abril de 1968.

BENTHAM, Jeremy. Uma Introdução aos Princípios da Moral e da Legislação. São Paulo: Abril, 1979. (Os Pensadores).

BIX, Brian. A Dictionary of Legal Theory. Oxford: Oxford University Press, 2004.

BIX, Brian. Jurisprudence: Theory and context. 3rd. Ed. London: Sweet and Maxwell, 2004.

BLOCK, Walter. Private property rights, Economic Freedom, and Professor Coase: a critique of Friedman, McCloskey, Medema, and Zorn. Harvard Law Hournal of Law \& Public Policy, vol. 26, no. 3, p 923, 2003.

BOBBIO, Norberto. Da Estrutura à Função: novos estudos de Teoria do Direito.Barueri: Manole, 2007.

BONNER, John. Introduction to the theory of social choice. Baltimore: John Hopkins University Press, 1986.

BRUE, Stanley L. História do pensamento econômico. Tradução da $6^{\mathrm{a}}$. ed. norteamericana. São Paulo: Pioneira Thomson Learning, 2005.

BUCHANAN, Allen. Etica, efficienza, mercato. Napoli: Liguori Editore, 1992.

BUCHANAN, James. Politics without romance: a sketch of positive Publico Choice Theory and its normative implications. In: BUCHANAN, J. et al (eds.). The Theory of Public Choice - II. Ann Arbor: The Michigan University Press, 1984. 
BUCHANAN, James. TULLOCK, Gordon. Il calcolo del consenso: fontamenti logici della democrazia costituzionale. Bologna: Il Mulino,1998.

BURROWS, Paul. VELJANOVSKI, Cento. The economic approach to Law. Londres: Buttlerworth, 1982.

BUSCAGLIA, Edgardo. RATLIFF, William. Law and Economics in developing countries. Stanford: Hoover, 2000.

CALABRESI, Guido. An Exchange: about Law and Economics: a letter to Ronald Dworkin. Hofstra Law Review, vol. 8, p. 553-562, 1979-1980.

CALABRESI, Guido. Some thoughts on risk distribution and the law of torts. Yale Law Journal, $n^{\circ} .70$, p. 499-553, 1961.

CHANG, Howard. A liberal theory of social welfare: fairness, utility and Pareto Principle. Yale Law Journal, vol. 110, 2000.

CHIARotTino, Alessandro A. R. Vilfredo Pareto e a Democracia: uma relação problemática. Dissertação (Mestrado em Ciência Política) - Faculdade de Filosofia, Letras e Ciências Humanas da Universidade de São Paulo, São Paulo, 2001.

CHORVAT, Terrence et al. Law and Neuroeconomics. GEORGE MASON UNIVERSITY SCHOOL OF LAW. Law and Economics Working Paper Series. Disponível em: http://ssrn.com/abstract $=501063$.

CIRILLO, Renato. The economics of Vilfred Pareto. London: Billing \& Sons, 1979.

COASE, Ronald. The firm, the market and the law. Chicago: University of Chicago, 1990.

COLEMAN, Jules. Efficiency, utility and wealth maximization. Hofstra Law Review, vol. 8,p. 509-544, 1979-1980.

COLEMAN, Jules. Risks and wrongs. Oxford: Oxford University Press, 2002.

COLEMAN, Jules. MURPHY, Jeffrie. Philosophy of Law: an introduction to Jurisprudence.. Revised ed. sine loco: Westview, 1990.

COOTER, Robert. ULEN, Thomas. Law and Economics. Boston: Pearson Addison Wesley: 2004.

COOTER, Robert. ULEN, Thomas. Derecho y Economía. Fondo de Cultura Económica: Cidade do México, 1997.

CREW, Michael A. TWICHT, Charlotte. On the efficiency of law: a public choice perspective. In: KLUWER ACADEMIC PUBLISHERS. Public Choice. vol. 66, n. 1, 1990. Netherlands. 
CRISP, Roger. Mill on Utilitarianism. New York: Routledge, 1997.

DALlAS, Lynne. Law and Public Policy: a socioeconomic approach. Durham: Carolina Academic Press, 2005.

DAU-SCHIMIDT, Kenneth. ULEN, Thomas. Law and Economics Anthology. $2^{\text {nd }} \mathrm{pr}$. Cincinnati: Anderson, 2002.

DEFFAINS, Bruno. KIRAT, Thierry. (eds.) Law and Economics in Civil Law coutries. [2 ${ }^{\text {nd }}$. Ed.]. London: Routledge, 2005.

DEMEULENAERE, Pierre. Homo oeconomicus. Paris: PUF, 2003.

DENOZZA, Francesco. Norme efficienti: l'analisi economica delle regole giuridiche. Milano: Giuffrè, 2002.

DIAS, João Álvaro (coord.). Os custos da justiça. Coimbra: Almedina, 2005.

DOWNS, Anthony. Uma teoria econômica da democracia. São Paulo: Edusp, 1999.

DUBNER, Stephen. LEVITT, Steven. Freakonomics. $7^{\mathrm{a}}$. Ed. Rio de Janeiro: Elsevier, 2005.

DUNLEAVY, Patrick. Democracy, bureaucracy and Public Choice: economic explanations in political science. London: Harverster Wheatsheaf, 1991.

DWORKIN, Ronald. Law’s Empire. Cambridge: Belknap, 1986.

DWORKIN, Ronald. Why efficiency? Hofstra Law Review. Vol. 8, p. 563-590, 19791980.

EINDENMÜLLER, Horst. Effizienz als Rechtsprinzip. 3a. ed. München, Mohr Siebeck, 2005.

FARREL, Martín Diego. Filosofía del Derecho y Economia. Buenos Aires: La Ley, 2006.

FREEMAN, Samuel (ed.). The Cambridge Companion to Rawls. Cambridge: Cambridge University Press, 2005.

FRIEDRICH, Carl Joachin. Perspectiva histórica da filosofia do Direito. Rio de Janeiro: Zahar, 1965.

FELDMAN, Allan. SERRANO, Roberto. Welfare economics and social choice theory. $2^{\text {nd }}$ ed. New York: Springer, 2006.

FONSECA, Eduardo Giannetti. Comportamento individual: alternativas ao Homem econômico. INSTITUTO DE PESQUISAS ECONÔMICAS. Estudos Econômicos. Vol. 20. $\mathrm{N}^{\mathrm{o}}$. Especial. Ano 1990. São Paulo. 
GEORGAKOPOULOS, Nicholas. Principles and methods of Law and Economics: basic tools for normative reasoning. New York: Cambridge University Press, 2005.

GONZALEZ-QUIJANO, Francisco. La curva de Pareto y la distribuición de la riqueza. Madrid: Colegio de Ingenieros de Caminos y Puertos, 1966.

GOTTINGER, Hans (ed.). Decision theory and social ethics. London: D. Reidel, 1976.

HARRIS, J. W. Legal philosophies. 2nd. ed. Oxfor: Oxford University Press, 2004.

HAUSMAN, Daniel. Economic methodology in a nutshell.: Journal of Economic Perspectives. Vol. 3. No. 2. p. 115-127. Primavera de 1989.

HAUSMAN, Daniel. MCPHERSON, Michael. Taking Ethics seriously: Economics and contemporary moral philosophy. Journal of Economic Literature. Vol. XXXI. 1993.

HIERRO, Liborio. Justicia, igualdad y eficiencia. Madrid: Centro de Estudios Políticos y Constitucionales, 2002.

HIRSCH, Werner. Law and Economics. 3rd. Ed. San Diego: Academic Press, 1999.

HOLDSWORTH, William. Bentham's place in English Legal History. California Law Review. Vol. 28. 1939-1940. p. 568 - 586.

HORWITZ, Morton J. Law and Economics: Science or Politics? Hofstra Law Review. Vol. 8, p. 905, 1979-1980.

JOSKOW, Paul. Contract duration and relationship-specific investments. The American Economic Review.vol. 77. no. 1. p. 168-185. Março de 1987.

KAPLOW, Louis. SHAVELL, Steven. Fairness versus Welfare. Harvard Law Review. Vol. 114, $\mathrm{n}^{\mathrm{o}}$. 4, fevereiro de 2001.

KAPLOW, Louis. SHAVELL, Steven. Notions of fairness versus the Pareto principle: on the role of logical consistency. Yale Law Journal, vol. 110, p. 2000.

KELLY, John Maurice. A short history of western legal theory. Oxford: Clarendon, 1994.

KELSEN, Hans. Teoria pura do Direito. 7a . Ed. São Paulo: Martins Fontes, 2006.

KNIGHT, Frank. Risk, uncertainty and profit. Washington D.C.: Beard books, 2002.

KOLM, Serge-Christophe. Modern Theories of Justice. Cambridge: MIT, 1996.

KONOW, James. Which is the fairest of all? Journal of Economic Literature. Vol. XLI, 2003.

MALLOY, Robin Paul. Law and Economics: a comparative aproach to Theory and Practice. Saint Paul: West Publishing, 1990. 
MAJUMDAR, Tapas. The measurement of utility. 3rd. ed. London: MacMillan, 1966.

MANKIW, N. Gregory. Introdução à economia: princípios de micro e macro economia. $2^{\text {a }}$. Ed. Rio de Janeiro: Elsevier, 2001.

MARCIANO, Alain. JOSSELIN, Jean-Michel. (eds.) From economic to legal competition: new perspective on Law and Institutions in Europe. Cheltenham: Edward Elgar, 2003.

MARKOVITS, Richard. Legal analysis and the economic analysis of allocative efficiency. Hofstra Law Review. Vol. 8, 1979-1980. p. 811.

MCCLOSKEY, Donald N. The rhetoric of Law and Economics. Michigan Law Review. Vol. 86. Nº. 4. p. 752-767. Fevereiro de 1988.

MEDEMA, Steven. Is there life beyond efficiency? Elements of a social Law and Economics. Review of Social Economy, vol 51, 1993.

MEDEMA, Steven. MERCURO, Nicholas. Economics and the Law: from Posner to Post-Modernism. 3a. impr. Princeton: Princeton University Press, 1999.

MEDEARIS, John. Joseph Schumpeter's two theories od democracy.Cambridge: Harvard University Press, 2001.

MICELI, Thomas. Economics of the Law.Oxford: Oxford University Press, 1997.

MILL, John Stuart. O Utilitarismo. São Paulo: Iluminuras, 2000.

MINDA, Gary. Teorie postmoderne del diritto. Bologna: Mulino, 2001.

MUELlER, Dennis. Public Choice. Cambridge: Cambridge University Press, 1979.

NEWMAN, Peter (ed.). The new Palgrave Dictionary of Economics and the Law. New York: Palgrave MacMillan, 2002.

NOBLES, Richard et al. (eds.) Introduction to Jurisprudence and Legal Theory. London: Elsevier, 2002.

NORTH, Douglass. Institutions, institutional chance and economic performance. $18^{\text {th }}$ impr. Cambridge: Cambridge University Press, 2005.

OKUN, Arthur. Equality and Efficiency: the big tradeoff. Whashington D.C.: Brookings Institution, 1975.

OLSON, Mancur. La logica dell'azione collettiva: i beni pubblici e la teoria dei gruppi. Milão: Feltrinelli, 1983.

PAGE, Alfred N. Utility theory: a book of readings. New York: Joh Wiley \& Sons, 1968. 
PARETO, Vilfredo. Traité de Sociologie Générale. Vol. II. Paris: Payot, 1933.

PARISI, Francesco. Positive, Normative and Functional Schools in Law and Economics. European Journal of Law and Economics. Vol. 18. No. 03. Dezembro de 2004.

PARISI, Francesco. SMITH, Vernon. (eds.) The Law and Economics of irrational behavior. Stanford: Stanford University Press, 2005.

PATTERSON, Dennis (ed.). A Companion to Philosophy and Leal Theory. Malden: Blackwell, 2005.

PEARSON, Heath. Origins of Law and Economics: the economists' new science of Law. New York: Cambridge University Press, 1997.

PINDYCK, Robert S. RUBINFEL, Daniel L. Microeconomia. 5a. ed. São Paulo: Prentice Hall, 2002.

PINHO, Diva Benevides. VASCONCELlOS, Marco Antonio S. de. (orgs.) Manual de economia. 5a. Ed. São Paulo: Saraiva, 2004.

PINHEIRO, Armando Castelar. SADDI, Jairo. Direito, Economia e Mercados. Rio de Janeiro: Elsevier, 2005.

POLINSKY, A. Mitchell. An introduction to Law and Economics. 3a. ed. Aspen: Nova Iorque, 2003.

POSNER, Eric. Law and social norms. Cambridge: Harvard University Press, 2002.

POSNER, Eric. ADLER, Matthew. (orgs.) Cost-benefit analysis: Legal, Economic and Philosophical perspectives.Chicago: University of Chicago Press, 2000.

POSNER, Richard. Conceptions of Legal "Theory": a response to Ronald Dworkin. Arizona State Law Journal. N ${ }^{0}$. 29. P. 377 - 388. 1997.

POSNER, Richard. Economic Analysis of Law. 6a. ed. Aspen: Nova Iorque, 2003.

POSNER, Richard. Frontiers of legal theory. Cambridge: Harvard University Press, 2004.

POSNER, Richard. Law and Legal Theory in the UK and in the USA. Oxford: Clarendon, 1996.

POSNER, Richard. Law, Pragmatism and Democracy. 2a . impressão. Cambridge: Harvard University Press, 2003.

POSNER, Richard. The economics of Justice. 2a. ed. Cambridge: Havard University Press, 1983. 
POSNER, Richard. The ethical and political basis of the efficiency norm in Common Law adjudication. Hofstra Law Review. Vol. 8, 1979-1980. p. 487-507.

POSNER, Richard. The problematics of Moral and Legal Theory. $3^{\mathrm{a}}$. impressão. Cambridge: Harvard University Press, 2002.

POSNER, Richard. The problems of Jurisprudence. Cambridge: Harvard University Press, 1990.

RAWLS, John. Uma Teoria da Justiça. 2a . Ed. São Paulo: Martins Fontes, 2002.

ROEMER, Andrés. (comp.) Derecho y Economía: una revisión de la literatura. México D.F.: Fondo de Cultura Econômica, 2002.

ROBERTSON, Dennis. Utility and all that and othe essays. 2nd. impression. Norwich: Jarrold and Sons, 1954.

ROSEN, Sherwin. WINSHIP, Christopher. Introduction: Sociological and Economic Approaches to the Analysis of Social Structure. The American Journal of Sociology, vol. 94, p. S1-S16, 1988.

RYAN, Alan (ed.). Utilitarianism and other essays. New York: Penguin Books, 1987.

SAMUELS, Warren. Pareto on policy. New York: Elsevier, 1974.

SEN, Amartya. WILLIAMS, Bernard. Utilitarianism and beyond. 4th. ed. Cambridge: Cambridge University Press, 1988.

SHAVELL, Steven. Foundations of Economic Analysis of Law. Cambridge: Harvard, 2004.

SHAVELL, Steven. Law versus Morality as regulators of conduct. American Law and Economics Review, vol. 4, nº. 2, p. 227-257, 2002.

SHÄFER, Hans-Bernd. OTT, Claus. The economic analysis of Civil Law. Northampton: Edward Elgar, 2004.

SHINOYA, Yuichi. Economy and Morality: the filosophy of Welfare State. Northampton: Edward Elgar, 2005.

SILVA, Marcos F. Ética e Economia: impactos na política, no direito e nas organizações. São Paulo: Elsevier, 2007.

SMITH, Adam. A riqueza das nações: investigação sobre sua natureza e suas causas. Vols. 1-3. 2a . edição. São Paulo: Nova Cultural, 1996.

SPIRITO, Ugo. El pragmatismo em la Filosofía contemporánea. Buenos Aires: Losada, 1920.

STEPHEN, Frank H. The economics of the law. Brighton: Wheatsheaf, 1988. 
SUNSTEIN, Cass. (ed.) Behavioral Law \& Economics. Cambridge: Cambridge University Press, 2004.

SZTAJN, Rachel. ZYLBERSZTAJN, Decio. (orgs.) Direito \& Economia: Análise Econômica do Direito e das Organizações. Rio de Janeiro: Elsevier, 2005.

TEO, Enrique. Elección pública hacia uma teoria de los fallos colectivos. Madrid: Instituto de Estúdios Fiscales, 2987

TULLOCK, Gordon. Two kinds of legal efficiency. Hofstra Law Review. Vol. 8, 19791980. p. 569.

VARIAN, Hal. Distributive Justice, Welfare Economics, and the Theory of Fairness. Philosophy and Public Affairs, vol. 4, nº 3, p- 223-247, primavera de 1975.

WEBER, Max. Economia e Sociedade. 4a. ed. Vol. 1. Brasília: Universidade de Brasília, 2004.

WILLIAMSON, Oliver. WINTER, Sidney. (eds.) The nature of the firm: origins, evolution and development. Oxford: Oxford University Press, 1993.

WINTER, Ralph. State Law, Shareholder protection and the Theory of the Corporation. Journal of Legal Studies, vol. 6, p- 251-292, 1977.

WITTMAN, Donald. O mito do fracasso da democracia: porque as instituições políticas são eficientes. Rio de Janeiro: Bertrand Brasil, 1999.

ZERBE JR., Richard. Economic efficiency in Law and Economics. Northampton: Edward Elgar, 2001. 